\title{
Stratigraphy of the Late Proterozoic Murdama Group, Saudi Arabia
}

\section{U.S. GEOLOGICAL SURVEY BULLETIN 1976}

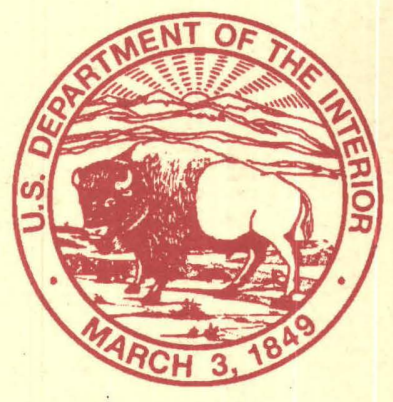



Stratigraphy of the Late Proterozoic Murdama Group, Saudi Arabia By ROBERT C. GREENE 


\title{
U.S. DEPARTMENT OF THE INTERIOR BRUCE BABBITT, Secretary
}

\author{
U.S. GEOLOGICAL SURVEY \\ Dallas L. Peck, Director
}

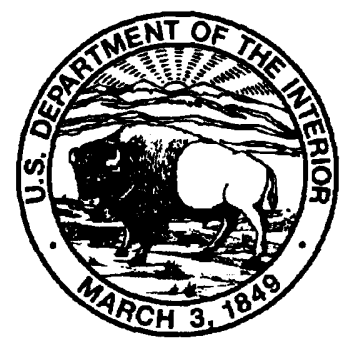

Any use of trade, product, or firm names
in this publication is for descriptive purposes only
and does not imply endorsement by the U.S. Government

Illustrations and plates edited by Dale Russell

Illustrations prepared by Fred Garrido, plates by Sara Boore

For sale by

Book and Open-File Report Sales

U.S. Geological Survey

Federal Center, Box 25286

Denver, CO 80225

Library of Congress Cataloging-in-Publication Data

Greene, Robert C.

Stratigraphy of the Late Proterozoic Murdama Group, Saudi Arabia / by Robert C. Greene.

p. cm. - (U.S. Geological Survey bulletin ; 1976)

Includes bibliographical references.

1. Geology, Stratigraphic-Proterozoic. 2. Geology-Saudi Arabia. 3. Murdama Group (Saudi Arabia). I. Title. II. Series.

QE75.B9 no. 1976

[QE653.5]

$557.3 \mathrm{~s}-\mathrm{dc} 20$

[551.7'15'09538] 93-1837 


\title{
CONTENTS
}

\author{
Abstract 1 \\ Introduction $\mathbf{2}$ \\ General geology of the Arabian shield 2 \\ Murdama formation and group 3 \\ General description of the Murdama 3 \\ Field study $\mathbf{5}$ \\ Open-file reports 6 \\ Rock nomenclature and metamorphism 6 \\ Arabic names 6 \\ Acknowledgments 6 \\ South part of the Afif belt 6 \\ Previous work 6 \\ Underlying rocks 7 \\ Structure 7 \\ Sections on the west limb of the Maslum synclinorium 7 \\ Jabal Murdama section 7 \\ Jabal Raqabah section 8 \\ As Sawadah sections 9 \\ Sections on the east limb of the Maslum synclinorium 9 \\ Jabal Zaydi section 9 \\ Jabal Farida section 10 \\ Jabal Damkh section 11 \\ Jabal Qatar section 12 \\ Wadi Sirrah section 12 \\ North part of the Afif belt 13 \\ Previous work 13 \\ Underlying rocks 15 \\ Structure 15 \\ Sections and other locality descriptions 16 \\ Wadi Jarir sections 16 \\ Jabal Ajam section 19 \\ Uqlat as Suqur quadrangle 19 \\ An Najady area 20 \\ Jabal umm Sammah section 20 \\ Jabal as Silsilah and Jabal Saq quadrangles $\mathbf{2 0}$ \\ Buqaya formation $\mathbf{2 1}$ \\ Conglomerate 21 \\ Qarnayn formation 21 \\ Jabal al Muwashsham sections 21 \\ Maraghan formation 21 \\ Section east of Jabal as Silsilah 21 \\ Hibshi formation 21 \\ Jabal Hibshi sections 22 \\ Jabal Khidar section $\mathbf{2 2}$ \\ Nonconglomeratic basal Hibshi 22
}


Afif belt depositional basin and sediment sources

South part 22

North part 23

Triangular diagrams 24

Environment of deposition 25

Rate of sedimentation 26

Sources and deposition of volcanic rocks 27

Jabal Hadhah belt $\mathbf{2 7}$

Previous work 27

Topography and structure 27

Sketch section 27

Discussion 29

Mistahjed belt 29

Previous work 29

Underlying rocks 33

Structure 33

Traverses and sections $\quad 34$

Jabal Hashishiyah sections $\mathbf{3 4}$

Section A $\mathbf{3 5}$

Section B $\mathbf{3 5}$

Correlation with Afif belt 36

Jabal Yafikh-Bir Zain area 36

Wadi Mistahjed section 36

Correlation with the Afif belt 36

Jabal Yafikh 36

Yafikh northeast traverse $\mathbf{3 6}$

Wadi al Farshah and Jabal Ibna Quirban 38

Traverses to Bir Zain and Wadi Rafiyah $\mathbf{3 8}$

Correlation 40

Bir Jarir area $\mathbf{4 0}$

Jabal Jasl section $\mathbf{4 0}$

Traverse northeast of Jabal Jasl $\mathbf{4 0}$

Traverse north of Jabal Bijad $\mathbf{4 0}$

Section north of Jabal Jarir $\mathbf{4 2}$

Jabal Jara traverse $\mathbf{4 2}$

Stratigraphic order and correlation $\mathbf{4 4}$

Sources of sediment and depositional history $\mathbf{4 4}$

Origin of the volcanic rocks and the Jarir formation 45

Junaynah belt $\mathbf{4 5}$

Previous work 45

Structure and underlying rocks 45

Murdama(?) group $\mathbf{4 5}$

Depositional basin 47

Correlation 47

Lithologic unity of the Murdama group 47

Geochronology 48

Radiometric ages from the Afif belt and adjacent areas $\mathbf{4 8}$

Discussion $\mathbf{5 0}$

Radiometric ages from the Mistahjed belt and adjacent areas $\mathbf{5 1}$

Radiometric ages from the Junaynah area $\mathbf{5 2}$

Interpretation $\mathbf{5 2}$

Plate-tectonic interpretation $\mathbf{5 2}$

References cited $\mathbf{5 5}$ 


\section{PLATES}

[Plates are in pocket]

1. Geologic map and columnar sections of the Murdama group in south part of the Afif belt.

2. Geologic map and columnar sections of the Murdama group in north part of the Afif belt.

\section{FIGURES}

1. Index map showing location of Saudi Arabia 2

2. Map of part of Arabian Shield showing Murdama group and gabbro and ultramafic rocks associated with Nabitah and Jabal Burqah belts 4

3-6. Photographs showing:

3. Jabal Zaydi, looking northwest along strike from line of measured section at unit $26 \quad 10$

4. Jabal Farida from the southwest $\mathbf{1 1}$

5. Wadi Jarir section B 17

6. Wadi Jarir section A 18

7-10. Triangular diagrams showing estimated modes of framework grains:

7. South part of Afif belt, Q-F-L system 24

8. North part of Afif belt and Mistahjed belt, Q-F-L system 24

9. South part of Afif belt, Qm-P-K system 25

10. North part of the Afif belt and the Mistahjed belt, Qm-P-K system 25

11. Geologic map of Jabal Hadhah belt $\mathbf{2 8}$

12. Geologic map of Mistahjed belt, showing locations of sections and traverses $\mathbf{3 0}$

13. Photograph showing Jabal Yafikh 38

14. Geologic map of Junaynah belt 46

15. Diagram showing radiometric ages and speculative age ranges of units $\mathbf{5 0}$

16. Palinspastic map of part of Arabian Shield showing $255 \mathrm{~km}$ of displacement on three major Najd faults removed $\mathbf{5 4}$

\section{TABLES}

1. Selected major layered rock units appearing in quadrangle maps of the Arabian Shield 3

2. Estimated modes of some volcanic rocks from the Wadi Sirrah section 13

3. Estimated modes of some igneous cobbles from conglomerate in the Wadi Sirrah section 14

4. Summary of group and formation names utilized by authors of quadrangle maps in the northern shield for the Murdama and some underlying and overlying layered rock units 16

5. Summary of informal unit names utilized for the Murdama group and some underlying units in quadrangle maps covering parts of the Mistahjed belt 32

6. Jabal Hashishiyah section A of the Murdama group 34

7. Jabal Hashishiyah section B of the Murdama group 35

8. Wadi Mistahjed section of the Murdama group 37

9. Descriptions of the Murdama group at the Yafikh northeast traverse 39

10. Jabal Jasl section of the Jarir formation $\mathbf{4 1}$

11. Section of the Murdama group north of Jabal Jarir 43

12. Radiometric ages from the Afif, Mistahjed, and Junaynah belts and adjacent areas 49 



\section{STRATIGRAPHY OF THE LATE PROTEROZOIC MURDAMA GROUP, SAUDI ARABIA}

\author{
By Robert C. Greene
}

\section{Abstract}

The Murdama group is in the upper part of the sequence of Proterozoic layered rocks in the Precambrian shield of Saudi Arabia. It consists of clastic sedimentary rocks and small amounts of limestone and volcanic rocks. The Murdama crops out in the eastern part of the exposed part of the shield, within $200 \mathrm{~km}$ of its margin. The principal outcrop area, herein designated the Afif belt, is $600 \mathrm{~km}$ long and has a maximum width of $80 \mathrm{~km}$. Two other significant outcrop areas lying to the south are designated the Jabal Hadhah and the Mistahjed belts.

The Murdama group unconformably overlies older plutonic rocks that range in composition from diorite to granite and volcanic rocks ranging from basalt to rhyolite. It is unconformably overlain in the north part of the Afif belt by sedimentary and volcanic rocks of the Jurdhawiyah group, and in many areas is intruded by younger granite.

In the south part of the Afif belt the Murdama group lies in the Maslum synclinorium, a structure characterized by tight folding near its northwest margin and open folding elsewhere. To the north, the synclinorium is much broken up by faulting, particularly by left-lateral faults of the Najd system.

Sections on the west flank of the Maslum synclinorium in the south part of the Afif belt have apparent thicknesses of about 5,300 $\mathrm{m}$ at Jabal Murdama, 5,700 $\mathrm{m}$ at Jabal Raqabah, and 1,400 and 4,000 $\mathrm{m}$ at As Sawadah. The strata in these sections consist mostly of greenish-gray, very fine to coarse-grained volcanic arenite that is poorly sorted and consists of angular grains. Basal conglomerates are thin and inconspicuous, but coarse arenite, locally pebbly, predominates in the Jabal Raqabah section. A prominent air-fall ash tuff caps Jabal Murdama, and an ash-flow tuff caps Jabal Raqabah.

Sections on the east flank of the synclinorium have apparent thicknesses of about $2,500 \mathrm{~m}$ at Jabal Farida, 3,600 $\mathrm{m}$ at Jabal Damkh, 12,400 $\mathrm{m}$ at Jabal Zaydi, and $16,800 \mathrm{~m}$, adjusted for folding, at Wadi Sirrah. Jabal Farida and Jabal Damkh are underlain principally by limestone of distinctive tan- and gray-weathering types, which has been named the Farida marble. Limestones of these and other colors occur in all the belts composing the Murdama and form a unifying element. The other sections consist mostly of sandstone similar to that at Jabal Murdama.

Manuscript approved for publication, February 15, 1991.
Sections in the north part of the Afif belt have apparent thickness of about 3,300 and 7,600 $\mathrm{m}$ at Wadi Jarir, $840 \mathrm{~m}$ at Jabal Ajam, 534 and $1,833 \mathrm{~m}$ at Jabal Muwasham, about $3,800 \mathrm{~m}$ adjusted for folding east of Jabal Silsillah, 4,900 $\mathrm{m}$ at Jabal Khidar, and $8,400 \mathrm{~m}$ at Jabal umm Sammah. The Wadi Jarir section consists of sandstone very similar to that at Jabal Murdama, with thin basal conglomerate and local ash tuff. The other sections consist of conglomerate, sandstone, and siltstone.

The predominance of silicic volcanic lithic grains in Murdama sandstones of the Afif belt indicates a source in a silicic volcanic belt, and discontinuous belts of such rocks lie to the southwest. Paleocurrent indicators also suggest a source from the southwest. In the north part of the belt, the lower part of the Murdama is probably a subaerial mass-movement or fluvial deposit. The strata in the rest of the belt were probably deposited at a prograding lacustrine or marine strandline. Near the northwest edge of the basin, particularly from Jabal Farida north, locally derived conglomerate was deposited and carbonate bank deposition prevailed for a time.

In the Jabal Hadhah belt, limestone is identical to that at Jabal Farida. It is apparently overlain by conglomerate that fines upward to sandstone and may be part of the Murdama.

Structure in the Mistahjed belt is more complex and the stratigraphic sequence is less certain than in the Afif belt. Murdama rocks have been assigned to a number of formations, and traverses were made across most units. The rocks include sandstone, siltstone, limestone, conglomerate, and volcanic rock; much of the volcanic rock may not be part of the Murdama group.

The source of sedimentary materials in the Mistahjed belt, as in the Afif belt, appears to be a belt of volcanic rocks lying to the southwest.

The Junaynah belt of sedimentary rocks lies to the west of the Mistahjed belt. The rocks consist of basal cobble conglomerate grading up to coarse- and finegrained sandstone. These rocks have been assigned to the Murdama group in the past, but I conclude that they should be restricted from it, because their tectonic setting and age appear to be different.

Radiometric ages suggest an age range of 650 to 615 Ma for the Murdama group, the laterally equivalent Hibshi formation, and the overlying Jurdhawiyah group in the Afif belt. Ages from the Mistahjed belt suggest that the Murdama rocks there are younger than $650 \mathrm{Ma}$ and ages 
from the Junaynah area suggest that the sedimentary section is younger than $610 \mathrm{Ma}$.

The Murdama group probably was deposited in a back-arc basin on a continental platform bounded on the west by an active volcanic arc above an east-dipping subduction zone. The position of the subduction zone, which was active during most of the deposition in the Afif belt, is marked by a belt of gabbro and ultramafic rocks herein named the Jabal Burqah belt. The subduction zone later stepped out to the southwest to the Nabitah belt, and Murdama strata were deposited in the Jabal Hadhah, Mistahjed, and smaller basins.

\section{INTRODUCTION}

Understanding of the complex geology of the Precambrian shield in Saudi Arabia (fig. 1) has progressed rapidly in recent years owing principally to mapping programs conducted by the Saudi Arabian Directorate General of Mineral Resources (DGMR), the U.S. Geological Survey (USGS), and the French Bureau de Recherches Géologiques et Minières (BRGM). The map-

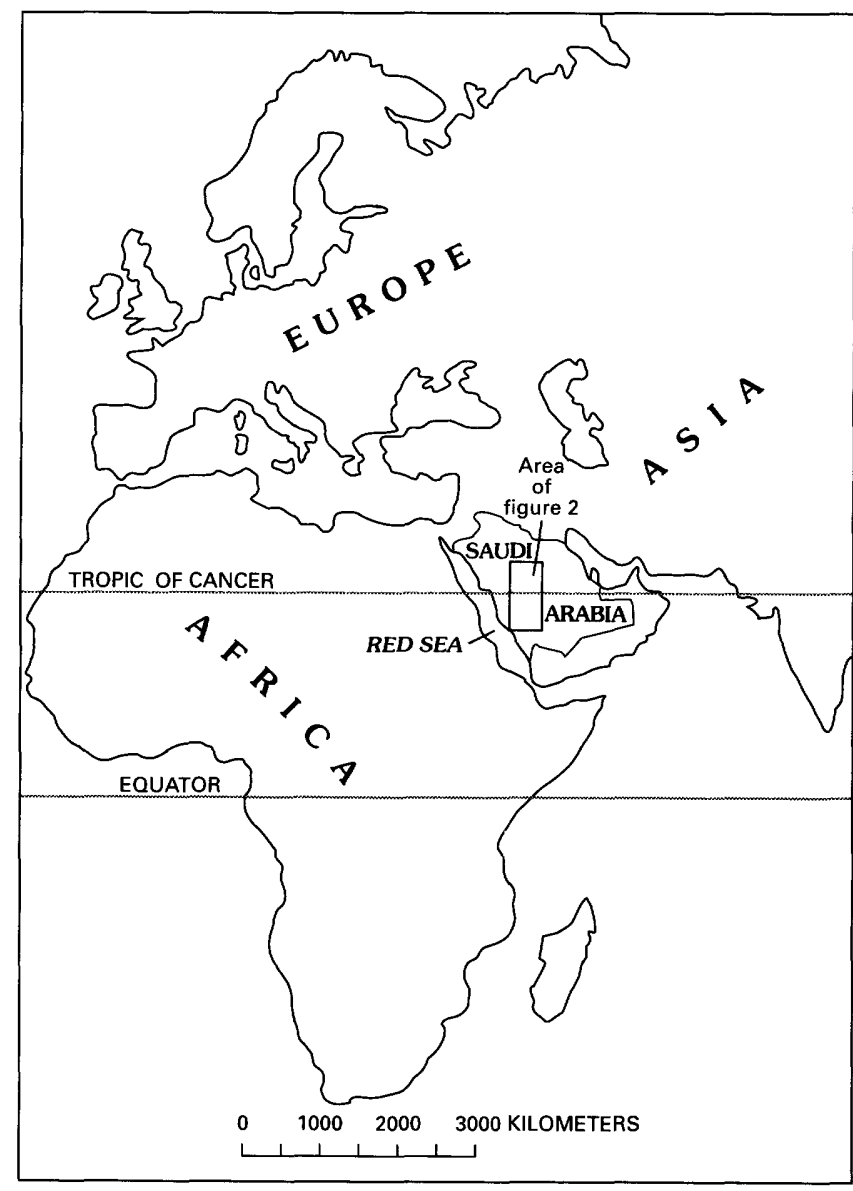

Figure 1. Index map showing location of Saudi Arabia and area of figure 2 . ping has also contributed to mineral exploration programs conducted by these agencies and by the Riofinex Geological Mission, Ltd.

A general stratigraphic column for the layered rocks of the southern part of the shield (table 1) was compiled early in the USGS mapping program and has provided a framework for the map units utilized on many quadrangle maps. A similar column was utilized by BRGM in the north-central part of the shield. However, the thickness, age, and mutual relations of the layered rocks are in fact not well known, and many units were extended from quadrangle to quadrangle or into distant areas without adequate justification.

During the mapping program, the need to make a compilation of the stratigraphic names in use, establish standards for naming units, and undertake systematic stratigraphic studies was recognized. Names in published and open-file reports were compiled in the Saudi Arabian Stratigraphic Lexicon (Fitch, 1980), a volume that contains over 1,500 entries. To guide future work, the Saudi Arabian Code of Stratigraphic Nomenclature (Stratigraphic Committee, 1979; 2d edition 1984) was established. An interagency group was set up to carry out stratigraphic studies.

The Murdama group is stratigraphically high in the sequence of layered rocks, its structure is simpler than that of older units, and exposures are locally excellent. Therefore, a study of the Murdama was undertaken, anticipating that a fairly detailed picture of the group was obtainable and might form a good basis for future work on lower units.

\section{General Geology of the Arabian Shield}

The Arabian shield is shown on the Geologic Map of the Arabian Peninsula, compiled by the U.S. Geological Survey and the Arabian American Oil Company or ARAMCO (1963). Although much of the information on this map has been superseded by more recent work, it still is an excellent general guide to the geology.

The Arabian shield (figs. 1,2) consists of sedimentary, volcanic, and plutonic rocks of Late Proterozoic age, 900 to approximately $570 \mathrm{Ma}$. The bulk of the rocks may be classified into five main types: (1) layered sedimentary and volcanic assemblages, variously metamorphosed, and forming strike belts many kilometers long; (2) plutonic rocks ranging in composition from diorite to tonalite, commonly foliate, and commonly intruding sedimentary-volcanic assemblages of similar composition; (3) voluminous foliate plutonic rocks ranging from tonalite to granite, and commonly forming plutonic belts separating major belts of layered rocks; (4) nonfoliate plutonic rocks consisting mostly of granite, some in subcircular masses, which locally intrude cogenetic vol- 
Table 1. Selected major layered rock units appearing in quadrangle maps of the Arabian Shield

[Adapted principally from Schmidt and others (1973) and Delfour (1979); Jurdhawiyah group is from Cole $(1985 ; 1986)$. Shammar group has been placed in various positions; see table 4. Ajal and Urd groups may not have any equivalents in southern shield]

\begin{tabular}{ll}
\hline $\begin{array}{c}\text { Southern shield } \\
\text { (before 1980) }\end{array}$ & \multicolumn{1}{c}{ Northern shield } \\
\hline & $\begin{array}{l}\text { Jibalah group } \\
\text { Jurdhawiyah group/Shammar group } \\
\text { Murdama group }\end{array}$ \\
$\begin{array}{l}\text { Halaban group } \\
\text { Ablah group }\end{array}$ & Hulayfah group \\
Jiddah group & Urd group \\
Bahah group & Ajal group \\
Baish group & \\
Sabya formation & \\
\hline
\end{tabular}

canic rocks; (5) small bodies of gabbro, and ultramafic rocks of various ages and origins, some in distinct belts.

The strike of belts of layered rocks is generally north-south to the south of Ranyah (U.S. Geological Survey and ARAMCO, 1963) but trends northwest in the area north and east of Ranyah and has a complex, irregular pattern in the northern and western part of the shield. Most of the layered rocks are folded, and contacts between layered units are mostly faults. Only in the younger units such as the Murdama are basal unconformities and stratigraphic contacts commonly visible. In contrast, intrusive contacts between plutonic rocks and other plutonic or layered rocks are commonly undisturbed and allow relative ages to be determined.

Major faults in the shield are mostly strike-slip or steeply dipping dip-slip structures; few thrust faults have been recognized. Some fault zones, particularly those accompanied by bodies of gabbro or ultramafic rocks such as serpentinite, may represent sutures between crustal blocks. Left-lateral strike-slip faults that strike northwest-southeast and are known as Najd faults formed late in the evolution of the shield and are an important feature. There are three principal zones of Najd faulting (fig. 2; U.S. Geological Survey and ARAMCO, 1963).

A summary of the geology of the Arabian shield with emphasis on the history of mapping and stratigraphic studies has been provided by Brown, Schmidt, and Huffman (1984). Other recent attempts to synthesize the geology of the Arabian shield (such as that of Stoeser and Camp, 1985) have employed an integrated, interpretive approach relating the rock units and structure to various plate-tectonic schemes. A summary of proposals for the evolution of the Arabian shield through plate-tectonic mechanisms is presented at the end of this report.

\section{Murdama Formation and Group}

The Murdama formation was named by Brown and Jackson (1960) for a sequence of "slate, phyllite, graywacke, and conglomerate" at Jabal Murdama. The Murdama formation was subsequently shown on several of the early 1:500,000-scale geologic maps of parts of the shield (Jackson and others, 1963; Brown and others, 1963a, b; Bramkamp and others, 1963). The Murdama was first raised to group status in the Bir Gamrah quadrangle by Overstreet and Whitlow (1972), but BRGM geologists continued to apply the term Murdama formation in the area between Jabal Murdama and Halaban (Afif belt of this report) (Leca and others, 1972; Letalenet and others, 1972; and other authors). The name Murdama, commonly as a group but locally as a formation, has continued to be used in areas that are extensions of the Afif belt to the north and west (Delfour, 1977, 1981a). It has also been given to rocks lying across the strike to the west in 1:100,000-scale maps prepared by BRGM geologists (Aguttes, 1971; Letalenet, 1977a, b; Brosset, 1979; and others). However, in the 1:250,000-scale compilations of the Al Hissu (Delfour, 1981a) and Al Madinah (Pellaton, 1981) quadrangles, these rocks were assigned to other groups, and the name Murdama was dropped for all rocks lying west of $\mathrm{Al}$ Hissu (fig. 2).

Schmidt and others (1973) adopted the name Murdama group for some rocks in the southern shield (Mistahjed belt of this report), particularly in the Jabal Yafikh quadrangle. Quadrangle mapping in parts of the Mistahjed and. Junaynah belts has further extended the distribution of rocks referred to the Murdama group in the southern part of the shield (Cornwall, 1973; Hadley, 1976; Schmidt, 1981, 1985; Kellogg, 1982a, b; Brock, 1983).

\section{General Description of the Murdama}

Rocks of the Murdama group consist principally of sandstone but include lesser amounts of siltstone, conglomerate, limestone, and volcanic rocks. They are exposed in a principal belt (Afif belt of this report) that is $600 \mathrm{~km}$ long and has a maximum width of $80 \mathrm{~km}$ (pl. 1). They also are exposed in several smaller belts-Jabal Hadhah, Mistahjed, and other unnamed areas-lying southwest of the Afif belt.

The maximum apparent thickness of the Murdama in the Afif belt is $17,500 \mathrm{~m}$; however, structural complications may have made this figure too large. The sandstone is very fine to coarse-grained and characteristically greenish in color. Bedding is typically thick and planar. Coarse-grained sandstone locally grades into pebbly sandstone or conglomerate, and very fine grained sandstone grades into siltstone. Conglomerates are relatively 


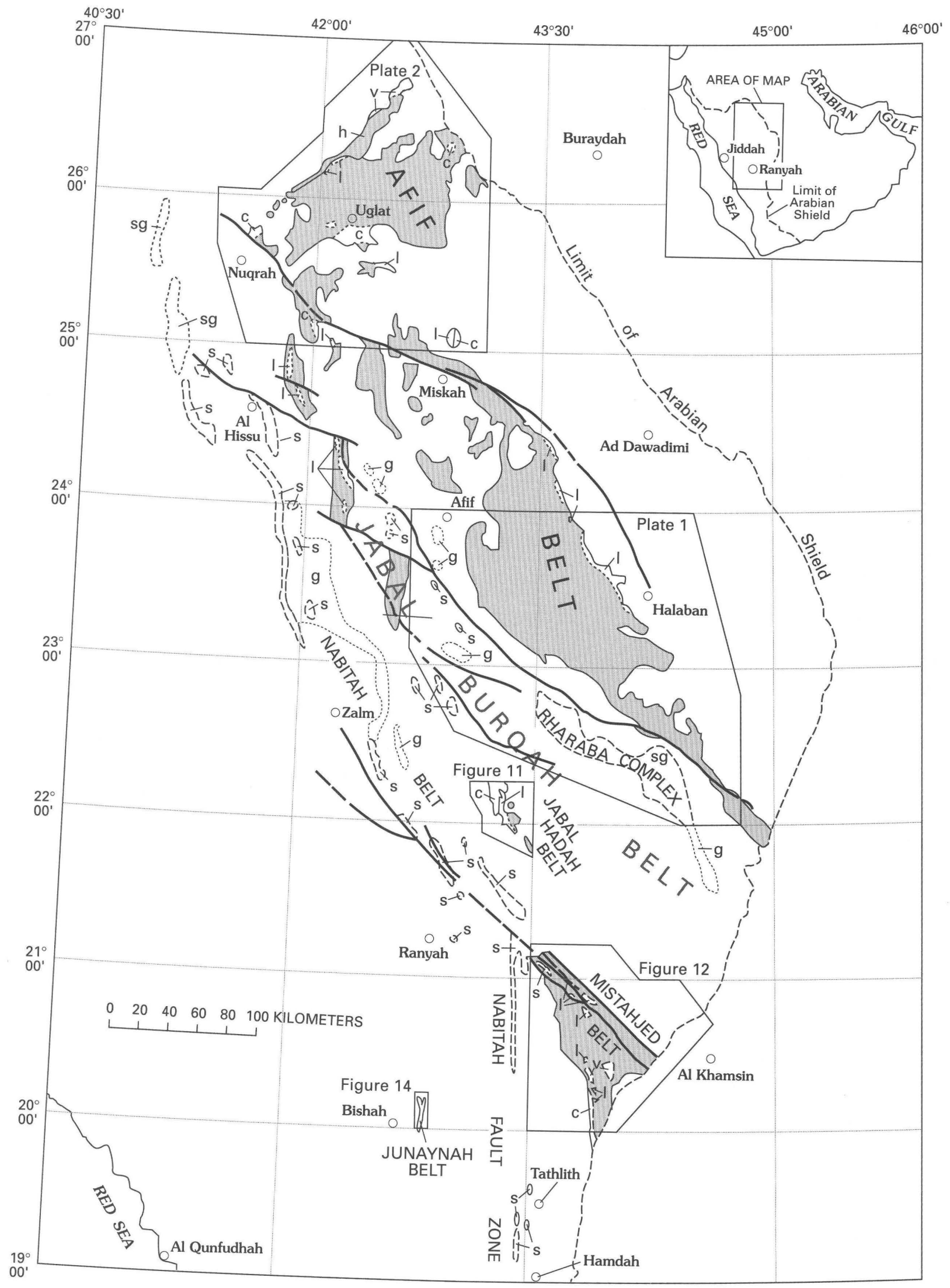

Figure 2. Part of Arabian Shield showing Murdama group and gabbro and ultramafic rocks associated with Nabitah and Jabal Burqah belts. Hibshi formation (h) located at north end of Afif belt. Geology adapted from 1:250,000-scale maps listed in index and locally from 1:100,000-scale maps (references given on pls. 1, 


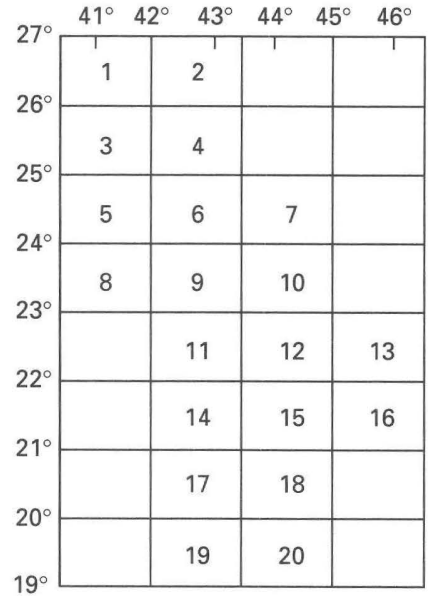

Index to 1:250,000-scale quadrangle maps and sources of mapping

1. Wadi ash Shubah; Quick and Doebrich, 1987.

2. Jabal Habashi; Johnson and Williams, 1984; Williams and others, 1986.

3. Nuqrah; Delfour, 1977.

4. Aban al Ahmar; Cole, 1986, 1988.

5. Al Hissu; Delfour, 1981a.

6. Miskah; Johnson, 1982; Pellaton, 1985.

7. Ad Dawadimi; Delfour and others, 1982

8. Mahd adh Dhahab; Kemp and others, $1982 \mathrm{~b}$

9. Afif; Letalenet, 1979.

10. Halaban; Delfour, 1979.

11. Zalm; Agar, 1984, 1988 .

12. Wadi ar Rika; Delfour, 1980

13. Wadi al Mulayh; Manivit and others, 1985.

14. Rawdah; Al Muallem and Smith, 1984, 1987.

15. Jabal Khida; Thieme, 1985, 1988.

16. Sulayyimah; Vaslet and others, 1985.

17. Wadi Bishah; Simons, 1984, 1988.

18. Wadi Tathlith; Kellogg, 1983; Kellogg and others, 1986.

19. Jabal al Hasir; Greenwood and others, 1986.

20. Jabal al Quar; Greenwood, 1981.

\section{EXPLANATION}

Murdama group, undivided-Mostly sandstone

Hibshi formation

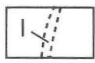

Limestone

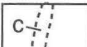

Conglomerate

Volcanic rocks

viti

exed exposures of serpentinite and other ultramafic rocks

Scattered exposures of gabbro, serpentinite, and other ultramafic rocks

$g \quad$ Scattered exposures of gabbro-May contain ultramafic rocks

Principal Najd fault-Dashed where approximate

Area covered by plates 1 and 2 and figures 11, 12, and 14

2; figs. 11, 12). Extent of Murdama group locally modified to agree with map of Cole and Hedge (1986). sparse but are locally important, as in the northwest part of the Afif belt and on the southwest flank of the Mistahjed belt (pl. 2, fig. 12).

Carbonate rocks are also relatively sparse but are locally important. Limestone is exposed in all belts except Junaynah and is a distinctive feature of the group. Volcanic rocks are not abundant, but ash-flow and airfall tuffs, basalt, andesite, and dacite occur locally.

\section{Field Study}

Fieldwork on the Murdama group consisted principally of measurement of sections and less detailed across-strike traverses, done intermittently between February 1982 and December 1983. Work was concentrated at first in the south part of the Afif belt, where type localities of several named units are found and the thickest sections were anticipated. It was then extended to the north part of the belt to study along-strike changes and address the problem of the age and correlation of the Hibshi formation, discussed below. Finally, work was extended south to the Jabal Hadhah, Mistahjed, and Junaynah belts.

Sections were measured by foot traverse across strike, after a study of aerial photographs revealed the alignments having the best outcrops. Enlarged photographs at a scale of about 1:12,000 were used as a base. During the traverses, lithologies and sedimentary features were described, samples were collected, and strike and dip were recorded.

The outcrops most commonly observed are on flat pediments and gentle to moderate slopes and ridge crests. Much can be seen, but these outcrops emerge irregularly through a mantle of weathered fragments and lack the clarity in detail of outcrops observed in stream cuts or cliffs. The proportion of outcrop may be moderate to large, but since finer-grained rocks tend to be more poorly exposed, the descriptions recorded may be slightly biased in favor of coarser rocks.

In the office, a domain was assigned to each field station, generally equal to half the distance to the preceding station plus half the distance to the subsequent one. Strike and dip were plotted or interpolated, scale and directional factors were applied, and the stratigraphic thickness of section traversed was calculated. Corrections for slope of the land were only locally necessary. In the Afif belt, columnar sections (pls. 1, 2) were erected by combining the appropriate domains, and although most of these have an exposed base, none have a stratigraphic top, so that they are all, in a sense, partial sections. In the Mistahjed belt, the same methods were applied where possible, but owing to fewer exposed bases and other uncertainties, the data are presented in tabular form as tables 6 to 11 . 
My observations are generously supplemented by descriptive material taken from available maps and reports.

\section{Open-File Reports}

Preliminary reports of this study of the Murdama have appeared in a series of open-file reports of the Saudi Arabian Deputy Ministry for Mineral Resources (Greene, 1983, in press a, b). The open-file reports contain the same columnar sections and tables that appear in this report and some discussion of stratigraphic nomenclature, but little interpretation. Detailed maps of the areas where the sections were measured are also included in the open-file reports.

\section{Rock Nomenclature and Metamorphism}

Clastic sedimentary rocks are in general referred to in this report by a name reflecting their predominant grain size, in accordance with the scale of Wentworth (1922). Characteristically poor sorting in these rocks, however, makes these names less than fully satisfactory. The colors of the rocks are according to the Rock Color Chart (Rock Color Chart Committee, 1975).

The petrology of the sandstones and siltstones is described according to the nomenclature of Pettijohn (1975, p. 211). It should be noted that this system separates arenite $(<15$ percent) from graywacke ( $>15$ percent) strictly by percentage of matrix.

Although the rocks of the Murdama group are commonly referred to as being of greenschist facies, metamorphic effects observed in thin section are slight. Some sandstones have minor secondary chlorite, calcite and (or) epidote in their matrices, and locally these minerals replace parts of framework rock fragments. A few rocks adjacent to intrusions such as at the Jabal umm Sammah section (pl. 2) contain secondary biotite. Therefore, I avoid using the prefix "meta-" when referring to these weakly metamorphosed rocks.

The carbonate rocks, however, are referred to as marble in many previous reports (Jackson and others, 1963; Delfour, 1979; Letalenet, 1979; Schmidt, 1981; and others). Although very fine to fine grained, the microtexture of these rocks is that of recrystallized spar with no trace of original depositional textures remaining. However, calcite recrystallizes easily, and it may be appropriate to reserve the term "marble" for coarser rocks. Therefore, I have followed the suggestion of Cole (1985, 1986) and referred to the carbonate rocks as limestone.

\section{Arabic Names}

For the reader unfamiliar with Arabic-speaking countries, some comments about the Arabic place names used in this report may be helpful.

"Jabal" means a hill, ridge, mountain, peak, or mountain range of almost any size. The spelling of the transliteration from Arabic is not at all fixed, sometimes appearing as jibal, jebal, or gebel.

"Wadi" means a watercourse, usually dry in the desert. The spelling is nearly always the same.

"Bir" means a well; the spelling also appears to be fixed.

Place names are more likely to be related to words with descriptive meaning than those based on English. Their transliteration can take many different forms, and confusion can result as to whether two different spellings represent the same place or not. Wadi Mistahjed of this report appears elsewhere as Mistajid or Mistajeed. Place names also frequently contain articles, such as "al," "an," or "as"; these are sometimes used and sometimes dropped. Finally, as elsewhere, features far apart can be given the same name. Wadi Jarir is nowhere near Bir Jarir and Jabal Jarir.

Arabic names used in this report do not necessarily conform to those officially established by the Foreign Names Committee of the Board on Geographic Names.

\section{Acknowledgments}

Edith Greene and Benjamin Greene as well as my local drivers and camp crews provided invaluble assistance in the field. Charles Williams, Brian Rooney, and Ahmed Hamdar al Bazli helped in the preparation of columnar sections. Reviews of the open-file reports incorporated into this one as well as discussions and inspiration were provided by fellow Stratigraphic Team members Thomas Moore of DGMR and John Kemp of BRGM.

\section{SOUTH PART OF THE AFIF BELT}

The south part of the Afif belt (pl. 1) is the central area of exposure of the Murdama group and contains the type section and the thickest sections.

\section{Previous Work}

The principal previous work on the Murdama group in the south part of the Afif belt is reported in the quadrangle maps by geologists of the BRGM, who produced a series of open-file maps at a scale of 1:100,000, followed by published compilations at 1:250,000. Most references in this report are to the latter series. The west, east, and south parts of the area are on the Afif (Letalenet, 1979), Halaban (Delfour, 1979), and Wadi ar Rika (Delfour, 1980) 1:250,000-scale quadrangles, respectively (pl. 1). 
Letalenet (1979) presented a simplified type section, 2,700 m thick, for the Murdama group as measured on the west flank of Jabal Murdama. This section is close to and probably in part identical to the section I measured. The rocks consist principally of sandstone and conglomerate; volcanic ash was not mentioned. Murdama rocks elsewhere in the Afif quadrangle are largely the same but include local rhyolitic tuff, rhyolite, andesite, and lenses of marble.

Delfour's (1979) Halaban quadrangle map includes the area of the Jabal Zaydi, Wadi Sirrah, Jabal Farida, and Jabal Damkh sections of this report. Delfour divided the Murdama group into Hibshi, Farida, and Zaydi formations. The Hibshi is a thin basal conglomerate, the Farida is a ridge-forming marble, and the Zaydi consists of sandstone with local conglomerate and forms the bulk of the Murdama.

In the Wadi ar Rika quadrangle, Delfour (1980) described the Murdama as mostly clastic rocks with subordinate volcanic rocks and marble. Basal conglomerates at various localities were described in some detail.

\section{Underlying Rocks}

Rocks immediately underlying the Murdama group on the southwest flank of the Afif belt have been named the Nuqrah formation of the Hulayfah group (Delfour, 1979,1980 ) east of long $43^{\circ} 30^{\prime} \mathrm{E}$. and the Afif formation, Jabal al Atulah facies, to the west (Letalenet, 1979).

The Nuqrah and Afif formations consist of a variety of volcanic flows, tuffs, and breccias ranging in composition from andesite to rhyolite. Farther to the southwest, rocks are mapped as older basement of granite, gneiss, and diorite in the east part (Delfour, 1980) and as granite, diorite, and gabbro intruding schist and gneiss of the An Nayzah formation in the west part (Letalenet, 1979).

On the northeast side of the Afif belt, rocks underlying the Murdama group are mapped as older basement consisting of gneissic diorite and quartz diorite adjacent to the Murdama and granite and granodiorite farther to the east. Also present are amphibolite, quartz diorite gneiss, schist, and marble mapped as Ajal group; units are locally intruded by granophyric granite (Delfour, 1979).

\section{Structure}

Rocks of the Murdama group in the south part of the Afif belt form a complex synclinal basin (pl. 1) named the Maslum synclinorium by Delfour (1979). Dips near the margins are generally inward, and where fold axes are not shown, homoclinal sequences prevail. Elsewhere, as at Jabal Raqabah and As Sawadah, the rocks are deformed into simple, open folds with vertical axial planes and axes plunging gently either northwest or southeast. The pattern of bedding orientations in the Afif (Letalenet, 1979) and Halaban (Delfour, 1979) quadrangles suggests the presence of cross-folds with northeast-trending axes, but they are of limited extent and may all be related to forceful injection of post-Murdama intrusive rocks.

Cleavage is a locally persistent feature that can be more prominent than bedding. Steeply dipping faults of small displacement, both across and along the strike of bedding, are locally present.

The Murdama group is intruded by several stocks and batholiths of biotite granite, which is in part porphyritic. These postorogenic intrusions are generally circular in plan and range in diameter from 2 to $30 \mathrm{~km}$. In the south part of the area, a complex of largely circular granitic bodies intrudes the narrowing belt of Murdama rocks and extends a considerable distance to the east. Contact-metamorphic aureoles surrounding the granite are generally narrow but may extend to $3 \mathrm{~km}$.

\section{Sections on the West Limb of the Maslum Synclinorium}

Sections on the west limb of the Maslum synclinorium (pl. 1) include Jabal Murdama on the north, Jabal Raqabah in the center, and As Sawadah near the south end of the Afif belt.

\section{Jabal Murdama Section}

Jabal Murdama is located $32 \mathrm{~km}$ southeast of Afif (pl. 2) and is the type locality for the Murdama formation (Brown and Jackson, 1960). The measured section is about $5,300 \mathrm{~m}$ thick and is in the same vicinity as the section measured by Letalenet (1974). The base of the section is at the contact with a distinctive dark-gray porphyritic andesite. This contact appears to be a fault here as no debris from the andesite is found in the Murdama rocks. However, the fault is probably a minor local structure, and the basal contact of the Murdama is an unconformity on most of the west side of the Afif belt (pl. 1).

The rocks of the Jabal Murdama section (pl. 1) consist of sandstone, siltstone, conglomerate, and local ash tuff. The dominant type of rock is sandstone, which grades nonsystematically from very fine to very coarse grained. Finer varieties grade locally into siltstone and coarser ones into pebbly sandstone and conglomerate.

Observed in the field, the sandstone is quite colorful. The predominant color is green and surface patina is black. Other colors include brown and gray. Comparison with the Rock Color Chart (Rock Color Chart 
Committee, 1975) reveals that most "green" rocks have a chroma no greater than 1 and are actually greenish gray to dark greenish gray (5GY6-4/1) and light olive gray to olive gray (5Y6-4/1).

The fine-grained sandstone is mostly in massive beds a meter or more thick, although beds commonly contain faint dark laminae a few millimeters thick. Some fine- and medium-grained sandstones form beds a few centimeters thick along which the rocks tend to break preferentially, but this is distinguished from nonbedding cleavage only with difficulty. Coarse-grained sandstone, pebbly sandstone, and conglomerate generally do not exhibit planar bedding but locally show irregular crossbedding, grading, and scour features. These features are prominent in the uppermost part of the section (units 28 to 31). Distinct upward-fining sequences of beds were rarely observed.

The sandstone is poorly sorted and consists of angular grains; this fact applies to all grain-size classes from very fine to very coarse. Measurements of grain size in thin section commonly reveal the presence of a size range of one-third of an order of magnitude or more, far more than a Wentworth size class (Pettijohn, 1975 , p. 29). Mineral grains, mostly quartz and feldspar, commonly have a smaller upper size limit than rock fragments; sparse rock fragments may extend the range even more. For example, a sample from unit 23 has mineral fragments of 0.1 to $0.3 \mathrm{~mm}$, rock fragments of 0.1 to $0.5 \mathrm{~mm}$, and a few rock fragments as large as $0.8 \mathrm{~mm}$. In rock descriptions in measured sections, the sandstones are placed in grain-size classes according to the Wentworth scale, but most include grains of more than one size class.

Microsopic examination of thin sections gives only limited information pertaining to the cause of the color variations in the bulk rock. If any correlation exists between the greenness of the rock and the composition of the matrix, it is that the greenest rock has an irresolvable matrix, and rock with well-crystallized epidote or chlorite in its matrix is gray.

The mineral composition of framework grains and matrix is less easily identified in siltstone but is apparently much the same as in the sandstone. Clay minerals may be more abundant, but the bulk of the fine particles are rock fragments.

Pebbly sandstone and conglomerate form a small part of the section (pl. 1). The matrix of these rocks is coarse to very coarse sandstone as described above. Pebbles of silicic volcanic rock and rare granite constitute a few percent to about 50 percent of this rock. Smaller pebbles are subangular, larger ones subrounded to well rounded. Sizes commonly range up to $2-\mathrm{cm}$ pebbles and rarely up to $10-\mathrm{cm}$ cobbles.

Several conspicuous yellow-green, well-lithified aphanitic ash tuff beds are present in the section. A prominent ash tuff bed (unit 27B) caps Jabal Murdama. The rock contains devitrified shards in a finer grained ash matrix.

The composition of the sandstone is remarkably uniform through the full range of grain sizes and from base to top of the section. The framework grains in most samples consist of the same rocks and minerals, although proportions vary (figs. 7, 9). Quartz and plagioclase commonly range from 5 to 30 percent each. Potassiumfeldspar (K-feldspar), commonly showing grid twinning, is present in about half of the samples studied and ranges from trace amounts to 10 percent, rarely to 25 percent. Heavy minerals are commonly present in trace amounts. They include, in approximate decreasing order of abundance, epidote, opaque minerals, hornblende, chlorite, muscovite, clinopyroxene, biotite, sphene, and zircon.

The rest of the framework grains, 30 to 85 percent of the total rock, are rock fragments. These are chiefly silicic volcanic rocks, largely clear to dusty rhyolite and dacite. Some have eutaxitic texture or collapsed pumice tubes and thus are derived from welded tuffs. Andesite and granite fragments are sparse.

The sandstones contain 1 to about 15 percent matrix or cement composed of epidote, chlorite, calcite, clay minerals, or unidentifiable material, probably very fine grained rock fragments. In some samples, rock fragments appear to be crushed by compaction and merge with matrix, leaving indistinct grain boundaries.

The sandstones described above are mostly lithic (volcanic) arenites, according to the classification of Pettijohn (1975, p. 211). The few that contain more total feldspar than rock fragments are arkosic arenites.

\section{Jabal Raqabah Section}

Jabal Raqabah is located at the southwest edge of the Maslum synclinorium $60 \mathrm{~km}$ southeast of Jabal Murdama (pl. 1). This section is about 5,700 m thick.

The Jabal Raqabah section is characterized by the presence of coarse and very coarse grained sandstone, pebbly sandstone, and local conglomerate (pl. 1). Brecciated sandstone including rhyolite fragments from the underlying volcanic rocks at the well-exposed base suggests that there is some fault movement on the basal unconformity. Overlying the basal breccia and a volcanic ash bed is a few hundred meters of fine- and mediumgrained sandstone; above this the section consists almost entirely of coarse, locally pebbly sandstone and sparse conglomerate. Colors of the sandstone are mostly greenish gray, light olive gray, and brownish gray. Bedding is not prominent and is mostly obscured by cleavage. The sandstones are poorly sorted and consist of angular grains. They contain 5 to 10 percent quartz and 1 to 10 percent, rarely as much as 30 percent, plagioclase (figs. 
7, 9). K-feldspar, present in less than half of the samples studied, ranges from 0 to 10 percent. Trace amounts of heavy minerals are also present. The rest of the framework grains, 60 to 90 percent of the total rock, are rock fragments, mostly silicic volcanic rocks. The matrix constitutes 1 to 10 percent of the rock. The samples studied show a somewhat narrower compositional range than those at Jabal Murdama (fig. 7). All are lithic (volcanic) arenites.

Conglomerate beds occur at scattered intervals in the lower two-thirds of the section. They constitute a very small part of the section but are nevertheless more abundant than at other sections in the south part of the Afif belt. Pebbles and cobbles range to $30 \mathrm{~cm}$ in diameter in the lower units but decrease in size in higher units. The pebbles consist mostly of granite, rhyolite similar to that at the base of the section, and sparse andesite. High in the section cobbles of sandstone or siltstone are seen.

Ash tuff beds containing sparse phenocrysts of quartz and plagioclase are present both high and low in the section (pl. 1, units $2 \mathrm{~A}$ and 24). A rhyolitic ash-flow tuff (unit 31) crops out near the top and forms a ridge crest. This rock contains abundant phenocrysts of $\mathrm{K}$ feldspar, plagioclase, and quartz, and trace amounts of hornblende and fayalite(?) in a shard matrix. Letalenet and others (1972) mapped this tuff (which they called "arkose") for a strike length of $15 \mathrm{~km}$.

\section{As Sawadah Sections}

The As Sawadah sections (pl. 1) are located 200 $\mathrm{km}$ southeast of Jabal Raqabah; here the Maslum synclinorium is only $14 \mathrm{~km}$ wide. This locality is near the end of the Afif belt of Murdama group rocks, which disappears under alluvium, dune sand, and Paleozoic rocks only $30 \mathrm{~km}$ southeast of the measured section. At the base of section A, a nonangular unconformity separates underlying rhyolite from the Murdama; other volcanic rocks lie farther down beneath the measured section.

The Murdama rocks in this area are deformed into open folds having vertical axial planes. Section A (pl. 1) begins at the base of the Murdama and ends at the first synclinal axis; section $\mathrm{B}$ begins there and extends to the first anticlinal axis. The thickness increases noticeably from section $\mathrm{A}$ at the edge of the outcrop belt to section $B$ further northeast, toward the interior of the basin.

Section A (pl. 1) consists of medium- and coarsegrained sandstone with considerable conglomerate for the first $350 \mathrm{~m}$ above the base. Pebbles and cobbles in the conglomerate are mostly rhyolite similar to that immediately underlying the section. Higher in section A, very fine and fine-grained, mostly greenish-gray sandstone predominates. Rare conglomerate beds contain granite and sandstone pebbles in addition to those of rhyolite. Section B (pl. 1) consists almost entirely of sandstone, fine grained in the upper part and fine, medium and locally coarse grained in the middle and lower parts. A $15-\mathrm{m}$ thickness of andesite constitutes the only volcanic rocks in either section.

The composition of the sandstones in these sections is similar to that of those at Jabal Murdama, except that $\mathrm{K}$-feldspar is sparse or absent (figs. 7, 9).

\section{Sections on the East Limb of the Maslum Synclinorium}

Sections on the east limb of the Maslum synclinorium include thick sections of sandstone with minor conglomerate at Jabal Zaydi and Wadi Sirrah and thinner, basal sections including limestone and coarse conglomerate at Jabal Farida, Jabal Damkh, and Jabal Qatar.

\section{Jabal Zaydi Section}

Jabal Zaydi (pl. 1) is a mountainous area of about 42 by $20 \mathrm{~km}$ in the central and eastern parts of the Maslum synclinorium. The section was measured in the part of the range located between 40 and $55 \mathrm{~km}$ southsouthwest of Halaban. The base of the Murdama group lies to the northeast of the measured section and is not exposed (Delfour, 1979). The following pre-Murdama rock types are exposed 5-10 km northeast of the base (Ajal Group and Older basement of Delfour, 1979): (1) plutonic breccia consisting of coarse-grained quartz diorite intruding finer, darker diorite, (2) metabasalt rich in hornblende and biotite, (3) two-mica syenogranite, and (4) hornblende diorite.

The Jabal Zaydi section is about $12,400 \mathrm{~m}$ thick and consists almost entirely of sandstone (pl. 1, fig. 3). Color, as elsewhere, is predominantly greenish gray but locally neutral gray. The lowermost 4,200 m (units 120B) consists mostly of medium- and coarse-grained sandstone. A 100-m-thick conglomerate (unit 2) is present near the base, and a few thin conglomerates are interbedded higher in the section. Most of the pebbles are rhyolite, rhyodacite, and perthite granite containing muscovite and biotite or chlorite. Pebbles of tonalite and of quartz are also present. The middle part of the section (units 21-26), 3,700 m thick, consists almost entirely of fine- and medium-grained sandstone, but it locally contains some very fine sandstone, siltstone, and limestone. The upper part of the section (units 27-37, about 4,100 m) contains mostly medium- and coarse-grained sandstone interbedded with local finer rock types. Conglomerate was not found in the middle and upper parts. The uppermost rocks of the Jabal Zaydi section (unit 38) are in the contact aureole of a younger granite intrusion. The 
rocks are hornfels and amphibolite, the later apparently derived from andesite and constituting the only volcanic rock present in the section.

The sandstones in the Jabal Zaydi section, like those at Jabal Murdama, are composed of poorly sorted, angular grains. Quartz-feldspar-lithic fragment ratios are similar to those at Jabal Murdama (fig. 7), but K-feldspar is rare (fig. 9). Matrix, 5 to 30 percent, consists in part of finely comminuted rock fragments and other irresolvable material and in part of well-crystallized epidote, chlorite, calcite, biotite, and muscovite. Thus the sandstones are lithic (volcanic) and arkosic arenite, and a few are lithic and arkosic graywacke (Pettijohn, 1975, p. 211).

\section{Jabal Farida Section}

Jabal Farida is on the east edge of the Afif belt, 25 $\mathrm{km}$ west of Halaban (pl. 1, fig. 4) and is the type locality for the Farida marble (limestone of this report). The section overlies a small body of porphyritic dacite (not shown on plate 1 or in Delfour, 1979) containing abundant plagioclase and sparse hornblende phenocrysts. The basal contact is locally brecciated, and I believe that this represents minor movement on an unconformity.
Wallace and Rowley (1986), however, believe that the contact is a thrust fault of some significance.

The Jabal Farida section is about 2,500 m thick and is composed of sandstone, conglomerate, and minor volcanic rocks in addition to limestone (pl. 1). The rocks at the base of the section (unit 1) consist of highly disturbed marble, sandstone, and dacite. These are overlain by thin units of stretched-pebble conglomerate and coarse, cataclasized sandstone. Overlying limestone forms the main ridge of Jabal Farida.

This limestone forms the distinctive feature of the Jabal Farida section. It is of substantial regional importance, as similar limestone has been identified at many localities in the central and northern parts of the Afif belt and in the Jabal Hadhah and Mistahjed belts. The limestone is of two distinct types, tan-weathering and gray-weathering. The two types of limestone normally form massive units tens of meters thick, but locally they may be thinly interbedded.

The tan-weathering limestone is medium light to light gray in bulk color and is composed of very fine to fine grained calcite with trace amounts of quartz. The texture is that of recrystallized spar devoid of sedimentary features. The tan surface is apparently caused by the weathering out of minute amounts of clays and iron ox-

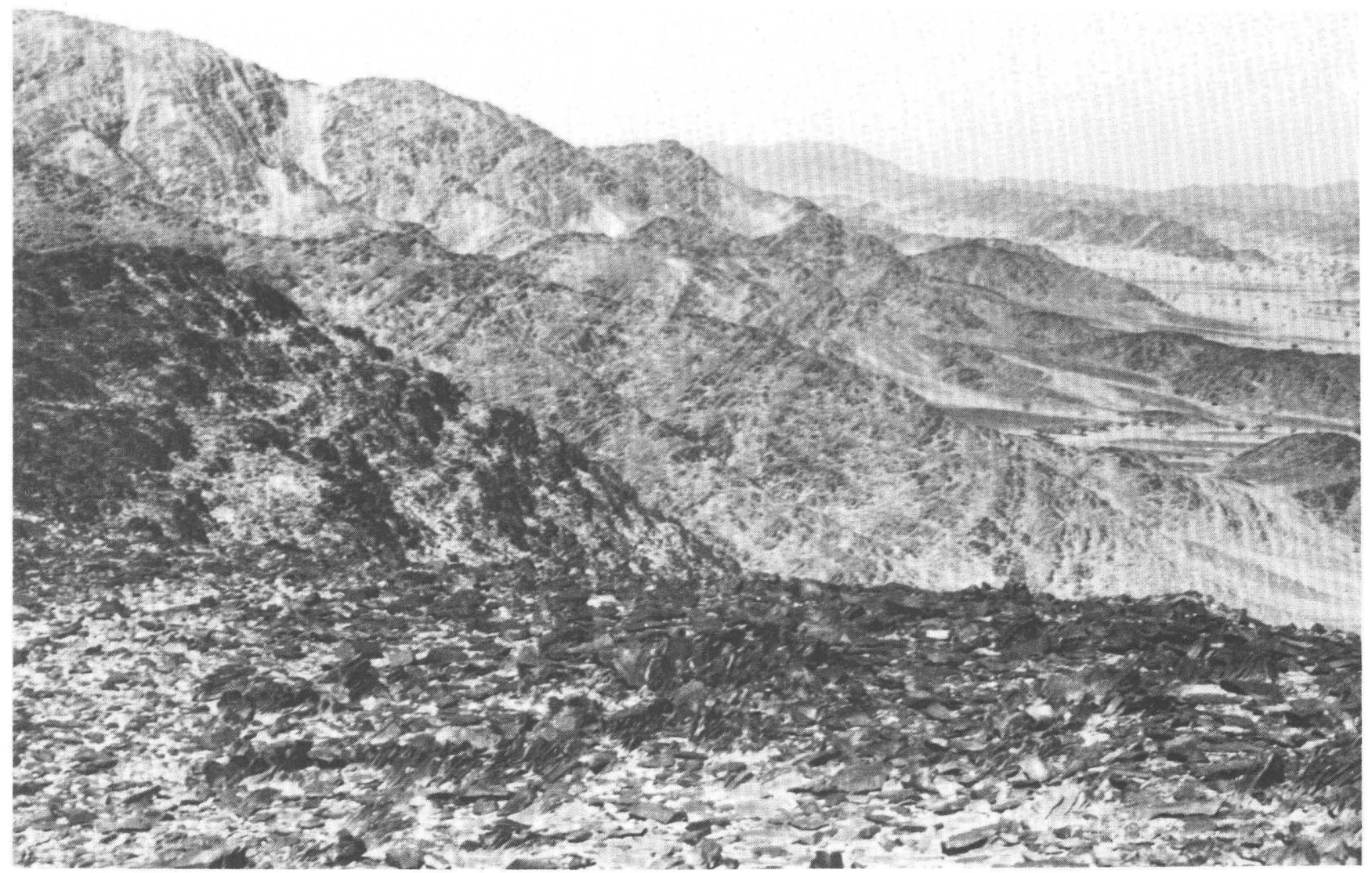

Figure 3. Jabal Zaydi, looking northwest along strike from line of measured section at unit 26 (pl. 1). Interlayered coarse-, medium-, fine-grained, and very fine grained sandstone. Cleavage mostly parallel to bedding; joints in several directions. Distance to horizon on left approximately $1 \mathrm{~km}$. 
ides. The surface is further characterized by solution fluting, which produces rough, even sharp-edged, corrugations on massive outcrops of gentle to moderate slope.

The tan-weathering limestone locally contains preserved algal structure (stromatolites). This feature is best viewed on a weathered surface, where it is seen to consist of a series of tiny troughs and ridges in a curved pattern resembling a sliced head of cabbage. Ridges are 1.5 to $2 \mathrm{~mm}$ apart. Whole colonial growths are not commonly found; however, the growths appear to expand in a fan pattern with decreasing curvature until they interfere with a neighboring growth.

The gray-weathering limestone is medium dark to dark gray in bulk color and fine to medium grained. Like the tan-weathering limestone, it is composed of recrystallized calcite. Solution fluting is also seen on surfaces, but algal structure is absent.

Beyond a covered interval, the section continues to the southwest of Jabal Farida. Olive-gray mediumgrained sandstone and abundant interbedded conglomerate form the next $600 \mathrm{~m}$ (units 8-13). Pebbles and cobbles consist of andesite, dacite, quartz diorite, and trondjhemite; neither granite nor rhyolite were found. Above is altered andesite, overlain by more sandstone.

\section{Jabal Damkh Section}

Jabal Damkh is located near the northeast edge of the Maslum synclinorium about $15 \mathrm{~km}$ northwest of Jabal Farida (pl. 1). The measured section crosses Jabal Damkh and continues southwest across low ridges and flats to Wadi Ghaghah, near the end of the Wadi Sirrah section. A well-exposed unconformity at the base overlies coarse-grained tonalite.

The Jabal Damkh section is about $3,600 \mathrm{~m}$ thick and is composited from several parts. The thicknesses of the lower units (1-3) are estimates. The lowest part, unit 1 (pl. 1), consists of sandstone, shale, and limestone, all highly deformed. Above this is tan-weathering limestone overlain by gray-weathering limestone, that form the main ridge of Jabal Damkh. Above are a few meters of conglomerate, more limestone, and a thick section of sandstone and minor conglomerate; the highest interbedded limestone beds are about $1,400 \mathrm{~m}$ above the base.

The presence of limestone interbedded with clastic rocks is a significant feature of this section, as such limestone cannot be structurally allochthonous. Also, upper and lower clastic parts of the section bear only slight

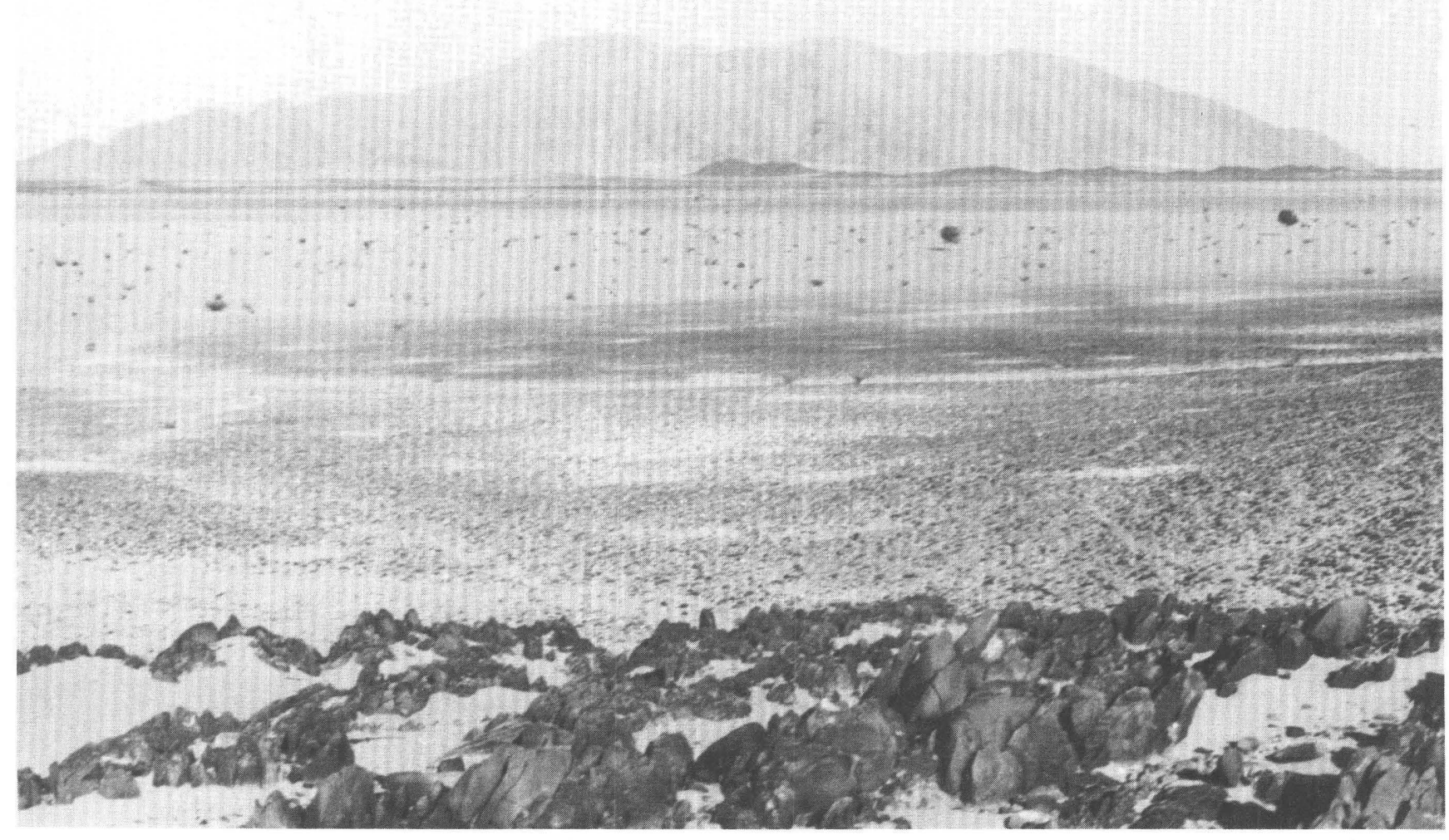

Figure 4. Jabal Farida from the southwest (about $500 \mathrm{~m}$ relief). Entire image facing observer is dipslope on tanweathering limestone (unit 7 of measured section, pl. 1). Low dark hills (50 m relief) at foot of jabal consist of sandstone and conglomerate (units 8-16). Surficial cover from dark hills to pediment slope in foreground (approximately $7 \mathrm{~km}$ ) is underlain by sandstone higher in the Murdama group. 
resemblance to the Jabal Farida section, which contains more coarse sandstone, conglomerate, and some volcanic rocks, both above and below the marble units.

Color, texture, and mineralogy of sandstone and conglomerate are similar to those in other sections.

\section{Jabal Qatar Section}

Jabal Qatar is located $6 \mathrm{~km}$ east of Jabal Damkh (pl. 1); a sketch section is described here to show the variety of rocks present in the short interval between the massive limestone units and the basement unconformity (pl. 1).

The $150 \mathrm{~m}$ of section exposed at Jabal Qatar beneath the limestone consists entirely of cobble conglomerate. The maximum cobble size increases up-section to as much as $40 \mathrm{~cm}$. Cobbles consist of diorite, quartz diorite, tonalite, and minor amounts of andesite. The quartz diorite and tonalite are similar to basement rocks below the Jabal Damkh section and to basement rock exposed $6 \mathrm{~km}$ to the south of Jabal Qatar.

\section{Wadi Sirrah Section}

The Wadi Sirrah section (pl. 1) is the thickest in the Afif belt and extends from a point $35 \mathrm{~km}$ west of Halaban westward for another $35 \mathrm{~km}$. The base of the section is at Wadi Ghaghah, $7 \mathrm{~km}$ on strike southeast of the top of the Jabal Damkh section. The top of the section is at the axis of the Maslum synclinorium.

The measured thickness of the Wadi Sirrah section, obtained in the same manner as the other sections, is about $26,000 \mathrm{~m}$, and the section is so illustrated on plate 1. However, this figure is surely excessive, especially if added to the Jabal Damkh section, about 3,600 m. Arguments cited below reduce the thickness of the lower part, units 1 to 23 .

A study of the map of the Halaban quadrangle (Delfour, 1979), or better still, of the photomosaics that form the base of the quadrangle map, shows that the part of the Wadi Sirrah section between Wadi Sarahi and the axis of the Maslum synclinorium west of Jabal Nidyan is well exposed and structurally simple. In the columnar section (pl. 1), this part is units 24 to 51 and is $14,800 \mathrm{~m}$ thick. Continuing a transect of the Maslum synclinorium west to the Jabal Raqabah section (in part in the Afif quadrangle; Letalenet, 1979), exposure is also good and folds are of open style. Plate 1 illustrates these features, but less perfectly than the quadrangle maps or photomosaics.

The rocks east of Wadi Sarahi, however, are more poorly exposed and apparently of more complex structure. The cross section on Delfour's map shows, I believe correctly, that the rocks from Wadi Sarahi to the top of the limestone at Jabal Damkh are complexly folded and of small stratigraphic thickness, perhaps about $2,000 \mathrm{~m}$. Taking the estimated thickness of limestone at Jabal Damkh, $785 \mathrm{~m}$, and adding 2,000 m for the repeated beds in units 5 to 9 of the Jabal Damkh section and units 1 to 23 of the Wadi Sirrah section and further adding $14,800 \mathrm{~m}$ for the well-exposed units 24 to 51 gives a total of $17,500 \mathrm{~m}$ as a maximum thickness for the Murdama group in this part of the Afif belt.

This figure, about $17.5 \mathrm{~km}$, is large and may be excessive considering that it approaches half of the thickness of the Earth's crust. However, a seismic-refraction profile crossing the Afif belt in the vicinity of the Jabal Zaydi section shows a clear-cut velocity boundary (Mohorovicic discontinuity) at $43 \mathrm{~km}$ depth (Healy and others, 1982), showing that, whatever it may have been during the Late Proterozoic, the present crustal thickness is well over twice the apparent thickness of the Murdama strata. Further, I emphasize that both the field observation of units to 24 to 51 and the outcrop pattern shown on the photomosiacs show the structure in this area to be homoclinal. The added thicknesses for units 1 to 23 and for the Jabal Damkh section are modest. Therefore, if the section is not in fact this thick, the reason is obscure.

The bulk of the Wadi Sirrah section consists of a remarkably monotonous sequence of sandstone. It is greenish gray, olive gray, and neutral gray, mostly fine and medium grained but locally coarse grained. Interbedded volcanic rocks include a small amount of andesite (unit 1), some dacite porphry in unit 23 , a bed of ash in unit 39 , and several layers of andesite in the top 1,200 m, units 48-51. Estimated modes of some of these rocks are given in table 2. Conglomerate and pebbly sandstone are confined to a few meters each in units $24,25,27,29,31$, and 33; all are between 11,000 and $13,600 \mathrm{~m}$ above the base of the section (as originally measured).

The sandstones, like those in the other sections in the Afif belt, are lithic (volcanic) arenite and sparse lithic graywacke (Pettijohn, 1975, p. 211) (figs. 7, 9).

Pebbles and cobbles in conglomerate and pebbly sandstone consist of granite, volcanic rocks, chert, and sandstone. Estimated modes of some of these clasts are given in table 3 . There are probably rocks similar to the rhyolite (sample no. 556-1) and andesite porphyry (no. 556-2) present in potential source areas to the southeast, but neither Letalenet (1979) nor Delfour (1979) gave specific descriptions of volcanic rocks in the Afif or Nuqrah formations. Rocks similar to the alkali feldspar granites (nos. 546-2, 553-3, 556-4) were reported from the Haml suite in the northeast part of the Zalm quadrangle (Agar, 1984), $90 \mathrm{~km}$ southwest of the conglomerate outcrops in the Wadi Sirrah section. The age of the Haml suite rocks is poorly constrained, but they are believed to postdate the Murdama group. The presence of 
Table 2. Estimated modes of some volcanic rocks from the Wadi Sirrah section

[Section shown on plate 1. p, phenocrysts; tr, trace; - , not found]

\begin{tabular}{|c|c|c|c|c|c|}
\hline 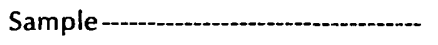 & 479 & 487 & 538 & 678 & 682 \\
\hline Unit --.-- & 1 & 6 & 23 & 49 & 51 \\
\hline Rock type - & $\begin{array}{l}\text { Altered } \\
\text { andesite }\end{array}$ & $\begin{array}{c}\text { Altered } \\
\text { andesite }\end{array}$ & $\begin{array}{c}\text { Dacite } \\
\text { porphyry }\end{array}$ & $\begin{array}{l}\text { Andesite } \\
\text { porphyry }\end{array}$ & Andesite \\
\hline Color & $\begin{array}{l}\text { Medium } \\
\text { dark gray }\end{array}$ & $\begin{array}{c}\text { Medium } \\
\text { light brownish } \\
\text { gray }\end{array}$ & $\begin{array}{l}\text { Light olive } \\
\text { gray }\end{array}$ & $\begin{array}{l}\text { Dark greenish } \\
\text { gray }\end{array}$ & Medium gray \\
\hline 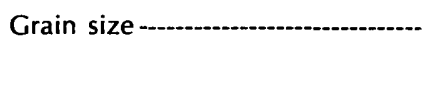 & Fine grained & Fine grained & $\begin{array}{l}\text { Phenocrysts up to } \\
3 \mathrm{~mm} \text {, aphanitic } \\
\text { groundmass }\end{array}$ & $\begin{array}{c}\text { Aphanitic } \\
\text { groundmass }\end{array}$ & Fine grained \\
\hline
\end{tabular}

\begin{tabular}{|c|c|c|c|c|c|}
\hline \multirow[b]{2}{*}{ Quartz -...- } & \multicolumn{3}{|c|}{ Primary minerals } & \\
\hline & 5 & 5 & - & - & - \\
\hline Plagioclase ------------------------- & 45 & 55 & $\mathrm{p}-35$ & $\mathrm{p}-25$ & 85 \\
\hline Clinopyroxene - & - & - & - & - & 10 \\
\hline 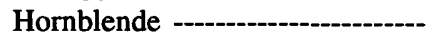 & 20 & - & - & - & - \\
\hline Opaque & $\mathbf{t r}$ & 1 & $\operatorname{tr}$ & - & 2 \\
\hline Groundmass - & - & - & 55 & 75 & - \\
\hline
\end{tabular}

Secondary minerals

\begin{tabular}{|c|c|c|c|c|c|}
\hline Actinolite -..-- & - & - & 10 & - & - \\
\hline Chlorite -..-- & 15 & 20 & $\operatorname{tr}$ & - & 3 \\
\hline Epidote - & tr & - & $\operatorname{tr}$ & - & - \\
\hline 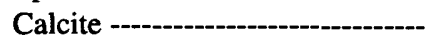 & 15 & 20 & $\operatorname{tr}$ & - & - \\
\hline
\end{tabular}

the alkali-feldspar granite cobbles provides suggestive evidence that some of these rocks were intruded and unroofed contemporaneously with deposition of the Murdama.

\section{NORTH PART OF THE AFIF BELT}

The Murdama group in the north part of the Afif belt was studied at measured sections at Wadi Jarir, Jabal Ajam, Jabal umm Sammah, Jabal Muwashsham, east of Jabal Silsilah, and Jabal Khidar. Additional data come from quadrangle mapping and other projects in the area.

Lithologies are similar to those in the south part of the Afif belt, but conglomerate is more abundant, and volcanic rocks play a locally important role. The Hibshi formation, a unit whose stratigraphic position is still a subject of controversy, crops out at the north margin of the belt.

\section{Previous Work}

The north part of the Afif belt of the Murdama group lies between lat $25^{\circ}$ and $27^{\circ}$ near the eastern edge of the Arabian shield (fig. 2, pl. 2). Early mapping at $1: 500,000$ scale in the part of this area east of long $42^{\circ}$ was by Bramkamp and others (1963; Wadi ar Rimah quadrangle) and mapping west of longitude $42^{\circ}$ was by Brown and others (1963b; Northeastern Hijaz quadrangle). Formation and group names utilized by these and other authors of quadrangle maps are listed in table 4.

The Hibshi formation was introduced in the 1:500,000-scale maps. The type locality is at Jabal Hibshi, near Samirah, in the Wadi ar Rimah quadrangale. Both maps show the Hibshi as stratigraphically above and not part of the Murdama group.

Recent mapping west of longitude $42^{\circ}$ by BGRM geologists was compiled as the Nuqrah 1:250,000-scale quadrangle by Delfour (1977). Delfour assigned rocks at the north end of Jabal umm Sammah and roof pendants in granite exposed to the northeast to the Hibshi formation (table 4). The Hibshi is shown as the lower part of the Murdama group; the upper part is called the Hadiyah formation, and rocks of this unit overlie the Hibshi on Jabal umm Sammah. The name Hadiyah was taken from a formation of possibly similar age, but located several hundred kilometers across the strike to the northwest (Hadley, 1974). 
Table 3. Estimated modes of some igneous rock cobbles from conglomerate in the Wadi Sirrah section

[Section in plate 1. p, phenocrysts; g, groundmass; tr, trace; X, present; - , not found]

\begin{tabular}{|c|c|c|c|c|c|c|}
\hline Sample --.......- & $546-1$ & $546-2$ & $553-3$ & $556-4$ & $556-1$ & $556-2$ \\
\hline Unit --.-- & 25 & 25 & 27 & 29 & 29 & 29 \\
\hline Rock type --.--- & Granite & $\begin{array}{l}\text { Alkali } \\
\text { feldspar } \\
\text { granite }\end{array}$ & $\begin{array}{l}\text { Alkali } \\
\text { feldspar } \\
\text { granite }\end{array}$ & $\begin{array}{l}\text { Alkali } \\
\text { feldspar } \\
\text { granite }\end{array}$ & Rhyolite & $\begin{array}{l}\text { Andesite } \\
\text { porphyry }\end{array}$ \\
\hline Color …........- & $\begin{array}{c}\text { Grayish } \\
\text { orange pink }\end{array}$ & $\begin{array}{l}\text { Light } \\
\text { olive gray }\end{array}$ & $\begin{array}{l}\text { Light } \\
\text { brownish } \\
\text { gray }\end{array}$ & $\begin{array}{l}\text { Light } \\
\text { brownish } \\
\text { gray }\end{array}$ & $\begin{array}{l}\text { Medium } \\
\text { gray }\end{array}$ & $\begin{array}{c}\text { Dark } \\
\text { greenish } \\
\text { gray }\end{array}$ \\
\hline Texture -------.-.. & $\begin{array}{l}\text { Graphic, } \\
\text { irregular }\end{array}$ & Graphic & $\begin{array}{c}\text { Fine } \\
\text { granular }\end{array}$ & Graphic & $\begin{array}{c}\text { Porphyritic, } \\
\text { micrograined } \\
\text { groundmass }\end{array}$ & $\begin{array}{c}\text { Porphyritic, } \\
\text { micrograined } \\
\text { groundmass }\end{array}$ \\
\hline \multicolumn{7}{|c|}{ Primary minerals } \\
\hline Quartz--.------ & 30 & $\begin{array}{l}\mathrm{p}-1 \\
\mathrm{~g}-35\end{array}$ & 35 & 35 & $\mathrm{p}-10$ & p-5 \\
\hline K-feldspar --.-- & 30 & $\begin{array}{l}\mathrm{p}-2 \\
\mathrm{~g}-60\end{array}$ & 65 & $\begin{array}{l}\mathrm{p}-1 \\
\mathrm{~g}-65\end{array}$ & $\mathrm{p}-20$ & - \\
\hline Plagioclase ----- & 40 & - & - & - & - & $\mathrm{p}-50$ \\
\hline Opaque -..--- & $\operatorname{tr}$ & $\operatorname{tr}$ & $\operatorname{tr}$ & $\operatorname{tr}$ & tr & $\mathrm{X}$ \\
\hline Groundmass --- & - & - & - & 一 & 65 & 45 \\
\hline \multicolumn{7}{|c|}{ Secondary minerals } \\
\hline Chlorite -------- & tr & - & - & $\operatorname{tr}$ & 3 & $\mathbf{X}$ \\
\hline Epidote --.---- & $\operatorname{tr}$ & 2 & tr & $\operatorname{tr}$ & 2 & $\mathbf{X}$ \\
\hline Calcite ------ & - & - & $\operatorname{tr}$ & $\operatorname{tr}$ & - & $\mathbf{X}$ \\
\hline
\end{tabular}

Recent mapping east of long $42^{\circ}$ by USGS authors was completed at $1: 100,000$ scale and later compiled onto 1:250,000-scale quadrangles. In the Jabal as Silsilah quadrangle (pl. 2, index C), du Bray (1983a) introduced the formation-rank names Bu'qaya, Qarnayn, and Maraghan lithic graywackes as subdivisions of the Murdama group (table 4); unnamed conglomerate was also assigned to the Murdama. In the Samirah quadrangle (pl. 2, index B), Williams (1983) applied the names Hibshi and Hadiyah much as they were used on the Nuqrah quadrangle, except that the Hibshi and Hadiyah are shown as lateral equivalents. The Qarnayn sandstone was extended from the Silsilah quadrangle but was left out of the Murdama group.

In the compilation of the $1: 250,000$-scale Jabal Habashi quadrangle (Johnson and Williams, 1984), the names Bu'qaya, Qarnayn, and Maraghan (with the for- mational term "sandstone") were used much as on the larger-scale maps, with the former Hadiyah being dropped in favor of the local term Maraghan formation (table 4). Inexplicably, only the Maraghan was assigned to the Murdama group. The Hibshi formation is reinterpreted to lie stratigraphically above the Murdama, as originally proposed by Bramkamp and others (1963).

In the Uqlat as Suqur quadrangle (pl. 2, index E), Cole (1985) subdivided the Murdama into major sandstone and conglomerate units and minor limestone and felsophyre (volcanic ash) units (table 4). The sandstone is contiguous with the adjacent Maraghan. The conglomerate is the basal unit and is named the Timiriyat conglomerate. Overlying the Murdama are extensive rocks of the Jurdhawiyah group, not recognized as separate from the Murdama on the 1:500,000-scale map (Bramkamp and others, 1963). A similar breakdown was 
carried over to the 1:250,000-scale Aban al Ahmar quadrangle (Cole, 1986).

Reinterpretation of pertinent parts of the Nuqrah 1:250,000-scale quadrangle has led to a more consistent picture of the stratigraphy. Johnson and Williams (1984) and Cole (1985) both interpreted the conglomerate at Jabal umm Sammah as a basal Murdama conglomerate, possibly the Timiriyat, and not the Hibshi formation. A sketch compilation in Cole and Hedge (1986) provided a suggested solution to border problems between Nuqrah and Aban al Ahmar, assigning certain rocks to the postMurdama Jurdhawiyah group and others to a preMurdama layered sequence. Basal Murdama unconformities that $I$ discovered at the Wadi Jarir and Jabal Ajam sections are a factor in this interpretation. Much of this is adopted on plate 2 .

I have correlated the Bu'qaya and Qarnayn formations as well as the Maraghan with the Murdama group, because (1) their lithologies are all similar, (2) they are located in adjacent areas, and (3) they do not appear to be separated by major unconformities.

\section{Underlying Rocks}

On the west flank of the north part of the Afif belt, pre-Murdama layered rocks are mapped as the Nuqrah and Afna formations of the Hulayfah group (Delfour, 1977, 1981a; table 4). They consist of volcanic rocks including basalt, andesite, and rhyolite, as well as some marble and conglomerate. Pre-Murdama plutonic rocks include gneiss and granite interpreted as "older basement" and post-Hulayfah dioritic to granitic rocks. The ages of some of the plutonic rocks have been reinterpreted (Cole and Hedge, 1986; Stacey and others, 1984), and many are now considered to be of post-Murdama age.

On the north flank of the Afif belt, underlying rocks consist mostly of plutonic rocks ranging in composition from gabbro to granodiorite and assigned to the Laban complex and Samirah quartz diorite (Johnson and Williams, 1984). Sparse layered rocks consist of schist and amphibolite.

In the Ata-Shara block (pl. 4) and areas to the southwest, pre-Murdama layered rocks consist of metaandesite and minor schistose metadacite (Cole, 1986). There and on the east flank of the Afif belt, preMurdama plutonic rocks of the Suwaj suite consist of diorite, quartz diorite, tonalite, and granodiorite.

\section{Structure}

The structure of the north part of the Afif belt (pl. 2) is more complex than that of the south part. The Maslum syıclinorium is broken up by northwest-trend- ing strike-slip faults of the Najd system, which along with other west- to northwest-trending faults are the dominant structural feature of the area (fig. 2, pl. 2).

The Murdama group is present in several small basins and one large basin forming the north end of the Afif belt. Basins and faults as named by Cole (1986) and Johnson and Williams (1984) are shown on plate 2. The basins are in part fault bounded, in part bounded by post-Murdama intrusive rocks, and locally overlapped by the younger Jurdhawiyah group. Only locally are the basins bounded by unconformable contacts with underlying rocks, such as the west edge of the Jarir South basin at the base of the Wadi Jarir measured section.

In the western part of the area, the Murdama rocks have moderate dips related to open folds and flexures. This is true of the Jarir South and Jarir North basins and contiguous areas west to Jabal umm Sammah; the dips steepen to the northeast into the Mahalani basin. Rocks in the Jabal Shuban and Ata-Shara blocks, the Bakrah arch, and the Maraghan basin, however, are characterized by steep dips and tight folds. These features continue to the northeast into the Jabal Habashi quadrangle, where the Qarnayn and Bu'qaya formations are likewise highly deformed.

Axes of open folds in the west part vary in trend but are commonly northerly. Axes of tight folds have northward trends in the south but change to northwest and east-west trends further north. Du Bray (1983a) believed that some folds are isoclinal.

Tight folding on east-west trends is especially visible in the well-exposed Jabal Shuban and Ata-Shara blocks. In the former, sandstone is tightly folded and limestone even more so, the latter having been ductilely deformed into largely disharmonic folds of decimeter to kilometer scale. Cole (1985) believed that much of the abundant conglomerate in the Ata-Shara block was deposited in a graben formed during early movement on the Ata, Shara, and related faults.

The Murdama group and Hibshi formation are characterized by the presence of fracture cleavage. Irregular to planar fractures are spaced 1 to $5 \mathrm{~cm}$ apart in sandstone but only a few millimeters apart in finer rocks. Cleavage appears to be a regional structure, but its relation to folding is poorly known (Johnson and Williams, 1984). Pebbles in some conglomerates are flattened and stretched parallel to the cleavage.

The Halaban-Zarghat fault is a major element in the dominantly left-lateral strike-slip Najd fault system. According to Cole and Hedge (1986), this fault had 40 $\mathrm{km}$ of left-lateral displacement before Murdama deposition, about $65 \mathrm{~km}$ after Murdama deposition, and $10 \mathrm{~km}$ of right-lateral displacement after post-Murdama plutonic emplacement of the Idhah suite.

The Lughfiyah-Shuban and Ata-Shara fault systems consist largely of dip-slip, high-angle reverse 
Table 4. Summary of group and formation names utilized by authors of quadrangle maps in the northern shield for the [Lateral equivalents are the writer's view, not necessarily shared by authors of quadrangle reports. I, lateral equivalent. See plate 2 for index to

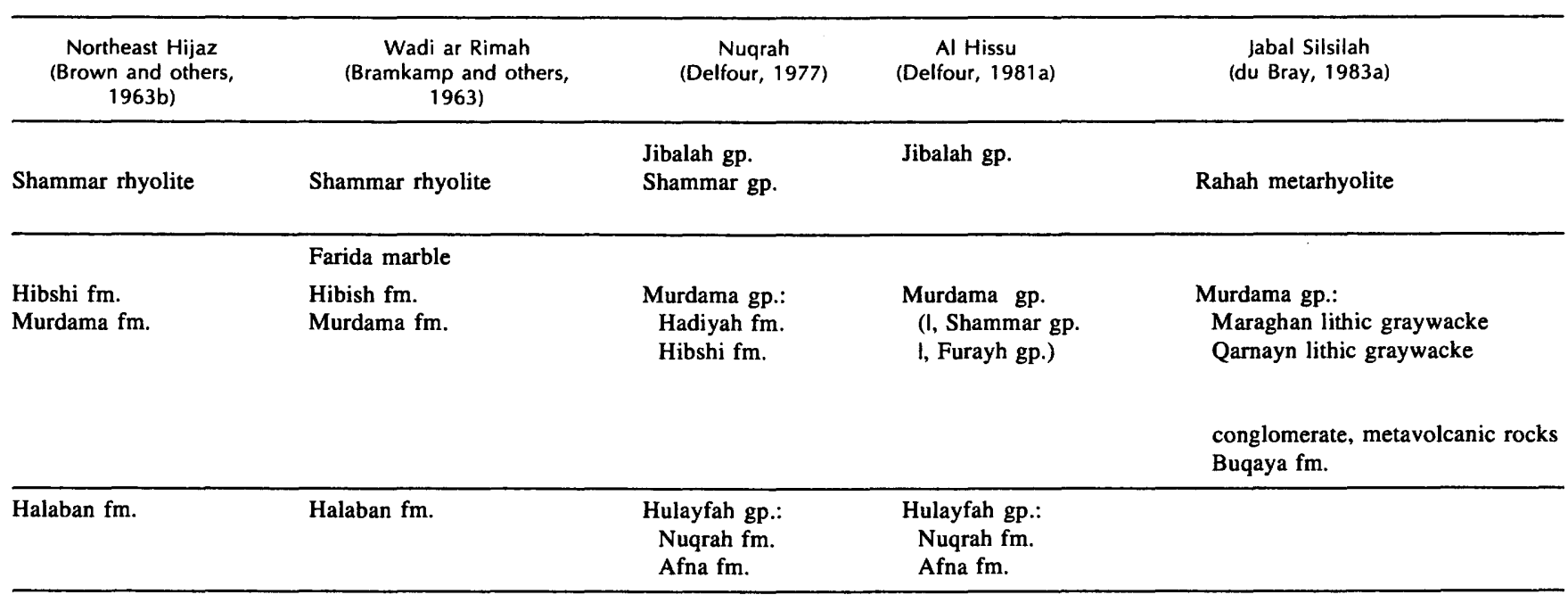

faults. The presence of serpentinite along its trace suggests that the Ata fault is a deep crustal feature (Cole, 1985).

The Safaq and Birka faults are strike-slip Najd faults, and both displace the Hibshi formation. Williams (1983) believed that they are both left-lateral. However, the map pattern suggests rather that the Safaq fault is right-lateral and that erosion has removed all but a narrow band of the Hibshi formation to the south of the fault. A projection of the Safaq fault is shown passing through Jabal Silsilah (pl. 2). Restoration of this rightlateral displacement would bring the easternmost area of the Bu'qaya formation into alignment with the rest of the Maraghan basin during deposition of the Murdama.

The Rahah fault zone north of Jabal Silsilah separates sedimentary rocks of the Qarnayn formation from those of the Maraghan. The fault zone consists of several strands, some of which are marked by occurrences of mafic and ultramafic rock and jasper suggesting that the faults penetrate deep into the crust (du Bray, 1983a). The direction and amount of displacement are unknown, but du Bray suggested that the fault zone may be a north-dipping thrust bringing rocks of the Qarnayn to the south over those of the Maraghan. Williams (1984), however, suggested that the fault zone may be a southdipping feature along which rocks of the Maraghan are thrust to the north. The fault forms a boundary between terrane to the north characterized by high-frequency magnetic anomalies from terrane to the south with a homogeneous magnetic signature. This feature led Cole and Hedge (1986) to propose a major crustal break, the "Murdama line," here.

The belt of the Hibshi formation at Jabal Khidar and parallel ridges to the southeast forms an open syncline. Southeast-dipping homoclines continue on strike to the southwest and northeast. Faulting and tight folding complicate the structure on Jabal Habashi and jabals lying farther northeast. Structure in the younger Jurdhawiyah formation (pl. 2, south-central part) is characterized by open folds with moderate dips. The eastwest belt of the Jurdhawiyah group running through Jabal Tamiyah (lat $25^{\circ} 35^{\prime}$, long $42^{\circ}$ ) is characterized by gentle dips. This aids in distinguishing them from the more structurally complex underlying Murdama group.

\section{Sections and Other Locality Descriptions}

The Murdama group in the north part of the Afif belt consists, as elsewhere, of sandstone and siltstone, conglomerate, minor limestone, and sparse but locally abundant volcanic rocks.

Sandstone and conglomerate are predominant in the southwest part of this area at the Wadi Jarir, Jabal Ajam, and Jabal umm Sammah sections and the Uglat as Suqur quadrangle. Farther north and east in the Jabal as Silsilah and Jabal Saq quadrangles, fine-grained sandstone and siltstone are predominant, and at the north end of the belt, the Hibshi formation contains sandstone, conglomerate, and volcanic rocks.

\section{Wadi Jarir Sections}

Wadi Jarir sections A and B (pl. 2) are located in the Jarir South basin $90 \mathrm{~km}$ south of Uqlat as Suqur. Section B is one of the thickest and best exposed in the north part of the Afif belt and consists mostly of rocks similar to those exposed at Jabal Murdama, $160 \mathrm{~km}$ to the southeast. Section A includes the same stratigraphic interval as the lower part of section B. A strike-slip 
Murdama and some underlying and overlying layered rock units

quadrangle maps]

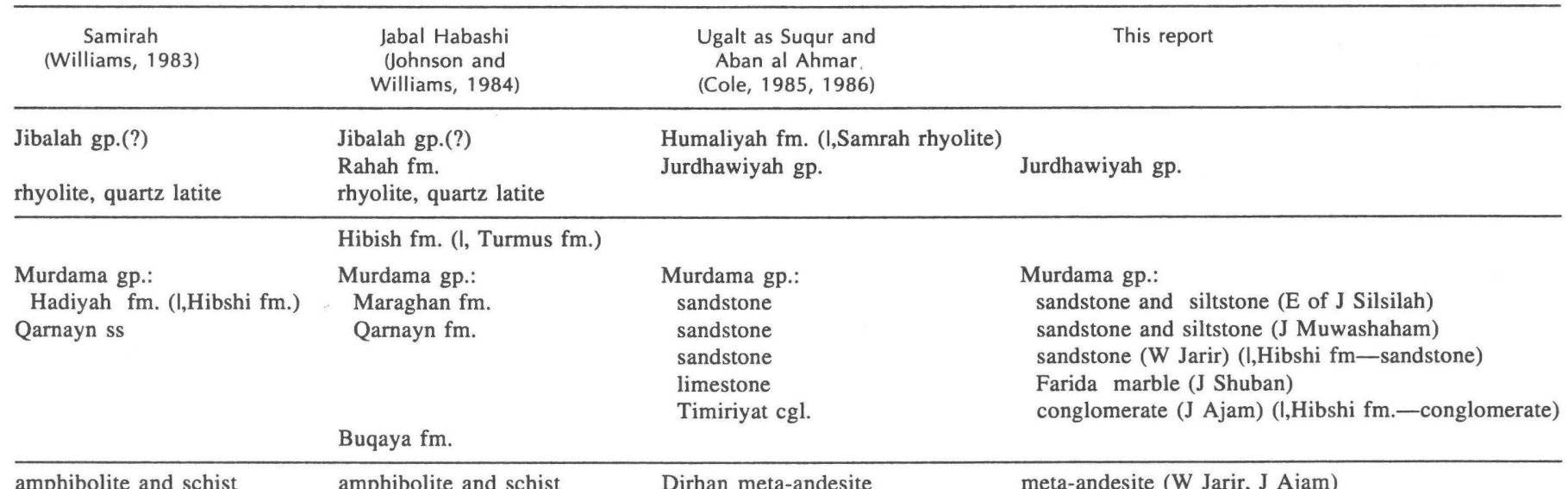

amphibolite and schist

amphibolite and schist

Dirhan meta-andesite

meta-andesite (W Jarir, J Ajam)

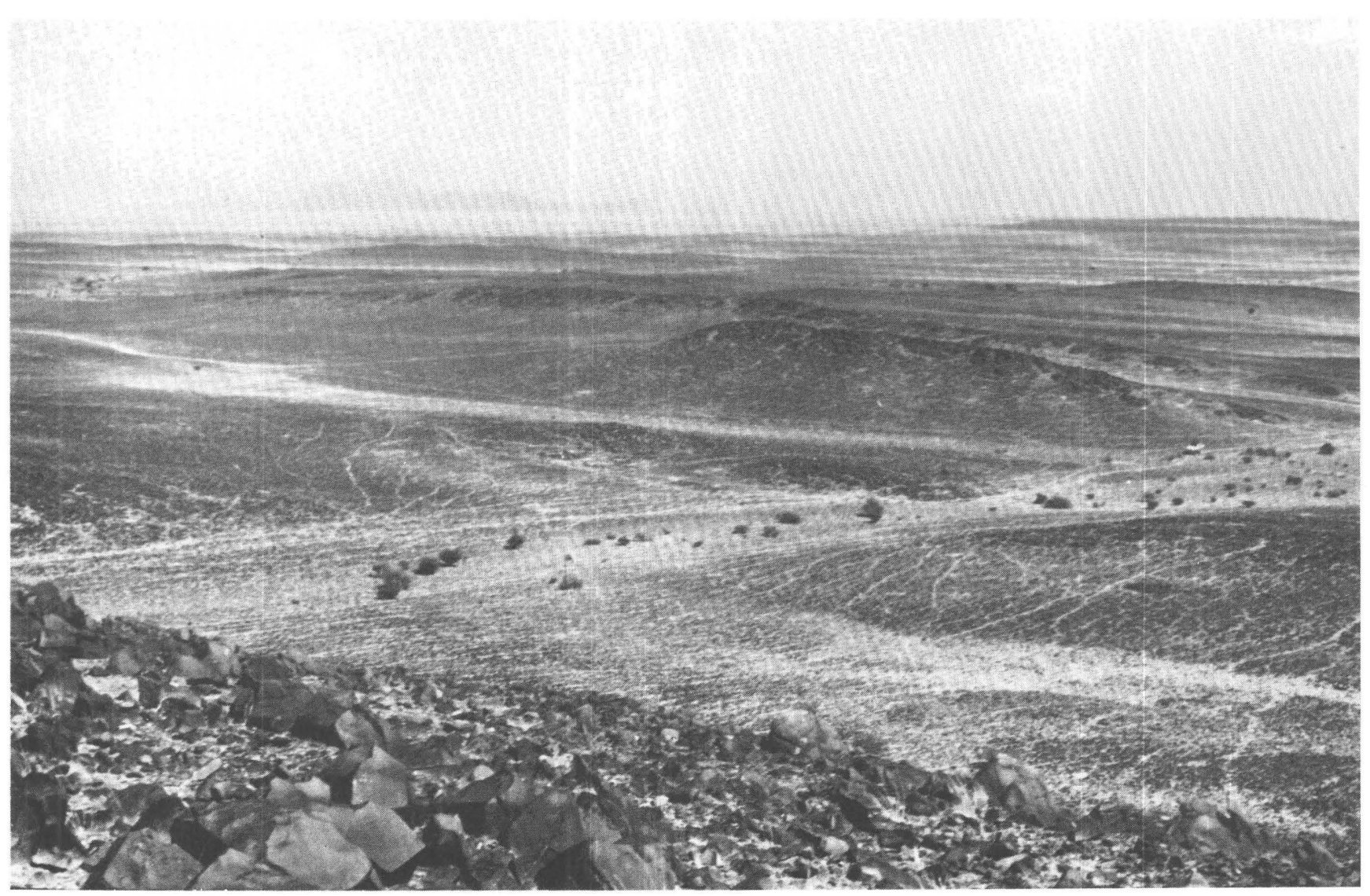

Figure 5. Wadi Jarir section (part B, units 37 to 50 (top); pl. 2). Interlayered fine-, medium-, and local coarse-grained sandstone forms small cuestas. Sand dune field in left background. Jabal Muqawqi, underlain by andesite of the Jurdhawiyah group, is in far distance, approximately $30 \mathrm{~km}$ away. Field vehicle, center far right. 
fault, parallel to the Halaban-Zarghat fault zone, separates the two sections (pl. 2, see also map of Cole, 1986). Section A is about $3,400 \mathrm{~m}$ thick, and section B is about $7,600 \mathrm{~m}$ thick.

The base of section A is at a well-exposed unconformable contact with meta-andesite; section B also lies above meta-andesite, but the contact is not well exposed.

The sections consist predominantly of mediumand coarse-grained sandstone (pl. 2, fig. 5). Fine-grained sandstone, pebbly sandstone, conglomerate, ash tuff, and other volcanic rocks occur locally. The colors are mostly light greenish to greenish gray and light olive gray; medium- to dark-gray or grayish-red colors are sparse. The sandstone is mostly in massive beds a meter or more thick, although it locally contains faint laminae a few millimeters thick. Some fine- and medium-grained sandstone has flaggy bedding.

The lowermost $1,200 \mathrm{~m}$ (units 1 to 4 ) of section A consists mostly of coarse-grained sandstone and conglomerate (fig. 6). Clasts near the base are meta-andesite and dacite identical to rocks underlying the section. Other clasts higher up include granite, tonalite, rhyolite, and yellow-green mudstone, a colorful rock that is a distinctive component of the Murdama group in the north part of the Afif belt. Above an interval of shale, the uppermost 2,000 $\mathrm{m}$ (units 7-18) consists of mediumand coarse-grained sandstone containing intervals of ash tuff.

Meta-andesite at the base of section B is unconformably overlain by medium- and coarse-grained sandstone containing local pebbles and cobbles of yellow-green mudstone, mafic and silicic volcanic rocks, and granite (units 20-24, 1,100 m). This is the apparent equivalent of units 1-4 of section A. Coarse-grained sandstone is predominant for the next 2,900 m (units 2537) and is at least in part equivalent to units $5-18$ of section A. Coarse-grained sandstone grades upward to predominantly medium-grained and some fine-grained sandstone for the upper 3,500 m (units 38-49). Unit 31 and unit 50 at the top consist of ash tuff.

All the sandstones are poorly sorted and consist of angular fragments. In pebbly sandstone and conglomerate, clasts less than $1 \mathrm{~cm}$ in maximum dimension are commonly angular whereas larger clasts are subrounded to well rounded. As elsewhere, the sandstones are volcanic arenites whose framework grains consist of quartz, plagioclase, sparse K-feldspar, trace amounts of heavy minerals, and rock fragments. Proportions are similar to those in other sections in the Afif belt (figs. 8, 10) except for a few samples relatively rich in K-feldspar.

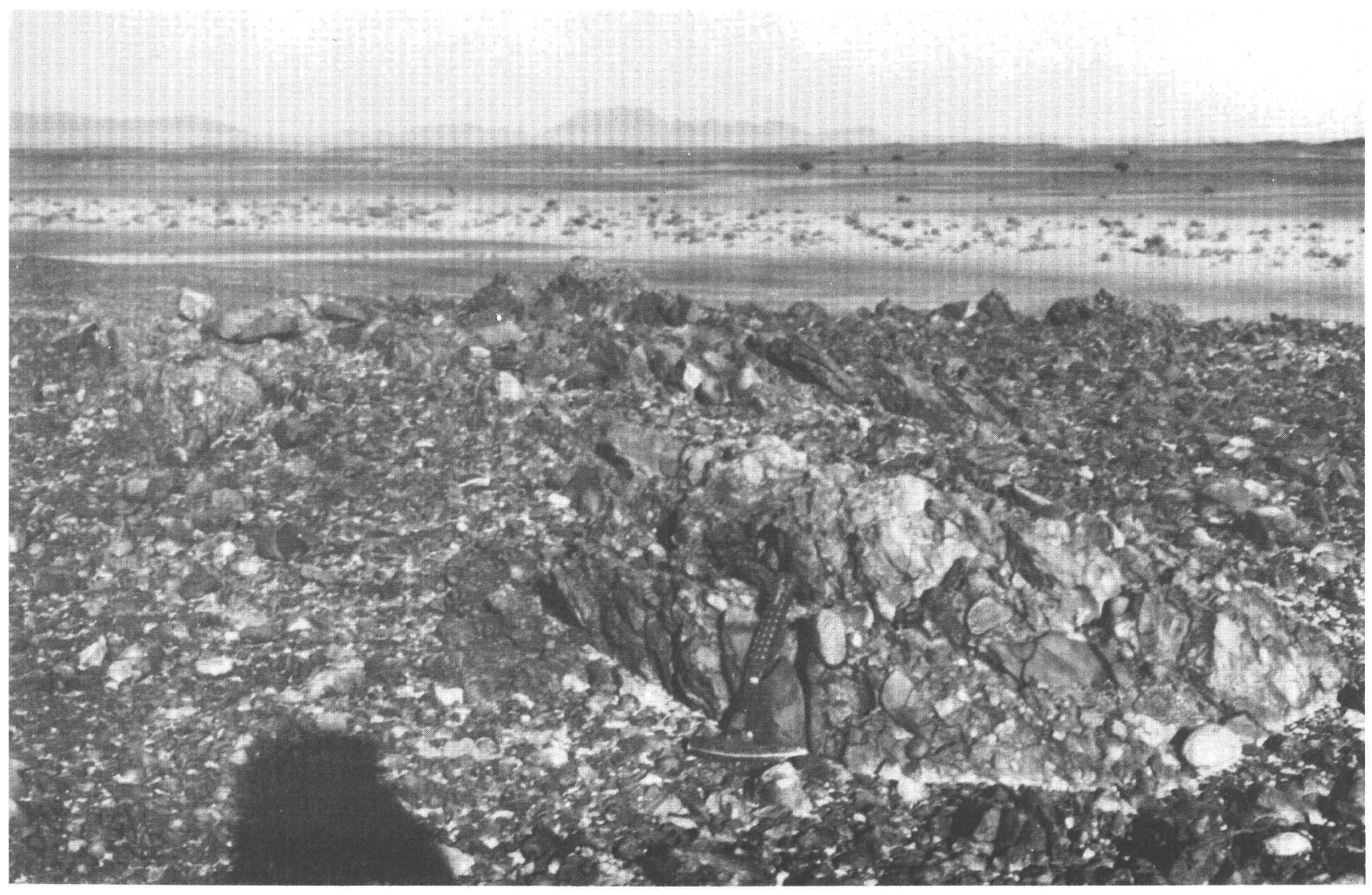

Figure 6. Wadi Jarir section (part A), conglomerate interlayered with sandstone, unit 4 (pl. 2). Cobbles as large as $20 \mathrm{~cm}$, mostly of rhyolitic rocks. Jabal Muqawqi approximately $30 \mathrm{~km}$ away at center horizon. Rock hammer $30 \mathrm{~cm}$ in length. 
Ash tuff beds are light olive gray and aphanitic. The rock is thoroughly compacted, but shard and pumice textures are locally preserved. Some of the tuffs contain 1 to 5 percent each quartz and plagioclase phenocrysts.

\section{Jabal Ajam Section}

The Jabal Ajam section (pl. 2) lies $32 \mathrm{~km}$ west of the Wadi Jarir section, and also rests unconformably on pre-Murdama meta-andesite. This conglomeratic section is probably correlative with the Timiriyat conglomerate of the Ata-Shara block. The top of the section is at an apparent fault. Abundant lag cobbles show that conglomerate persists to the west as shown by Delfour (1977), but exposure is poor.

The measured section is about $840 \mathrm{~m}$ thick and consists almost entirely of cobble and boulder conglomerate. The basal unit contains chiefly clasts of metaandesite similar to that beneath the section. Higher in the section, volcanic clasts persist along with clasts of tonalite and quartz diorite and clasts of sandstone similar to the sandy matrix.

\section{Uqlat as Suqur Quadrangle}

The Uqlat as Suqur quadrangle (pl. 2, index E) occupies the center of the north part of the Afif belt, and much of it is underlain by the Murdama group. Sandstone (unnamed) constitutes the major map unit, but Cole (1985) split out important conglomerate and limestone units. The following description is from Cole, supplemented by my observations at two localities.

Murdama group sandstone is commonly poorly exposed but is best seen in the Bakrah arch and the Jarir North basin. The sandstone is typically green and dominantly fine grained and thinly bedded. It consists of volcanic rock fragments of intermediate composition characterized by aligned plagioclase microlites and plagioclase phenocrysts, felsic volcanic rock fragments, plagioclase and quartz grains, and quartz-feldspar grains derived from plutonic rocks. Matrix consists of very fine grained rock fragments, chlorite, epidote, and calcite.

I briefly observed rocks of the Murdama group in the Jarir north basin directly south of Jabal Akkash. The rocks are mostly medium-gray to greenish-gray fine- to medium-grained sandstone locally containing interlayered meta-andesite, both similar to those in the Wadi Jarir section. Some dark-gray tuffaceous siltstone in the section is similar to that in the east-of-JabalSilsilah section in the Maraghan basin. I estimate the thickness of the Murdama rocks in the Jarir North basin to be at least $4,500 \mathrm{~m}$.

Two beds of volcanic ash (Felsophyre member of Cole, 1985) as much as $20 \mathrm{~m}$ thick crop out in the AtaShara block near the west boundary of the quadrangle.
The rock consists of 5 to 10 percent phenocrysts of sodic plagioclase, quartz, and sparse $\mathrm{K}$-feldspar in fine-grained groundmass. A few percent of rounded, detrital grains of strained quartz are also present.

Conglomerate is widespread and is a mappable unit, especially in the Ata-Shara block. It was named the Timiriyat conglomerate after a jabal of that name near Uqlat as Suqur (pl. 2). Cole believed that the conglomerate is generally basal to the Murdama group, although only one segment of the basal unconformity is exposed, $15 \mathrm{~km}$ due east of Uqlat as Suqur. The thickness of the conglomerate is great but indeterminate and probably highly variable along strike. The conglomerate consists of subangular to subrounded cobbles and some boulders of mostly meta-andesite, diorite, and granodiorite granophyre. These rocks are identical to the Dhiran metaandesite (table 4) and plutonic rocks of the Suwaj suite, older units that crop out in the quadrangle. Other clasts include metadacite and other felsic volcanic rocks, microdiorite, vein quartz, marble, and sandstone. The clasts are cemented by secondary epidote, quartz, and calcite. The conglomerate is poorly sorted and poorly bedded, and contains few sedimentary structures except for local cut and fill channels. Throughout the Ata-Shara block, the conglomerate is schistose and displays variably stretched clasts.

Limestone (marble of some authors) is locally present at or near the base of the Murdama group. In the Jabal Shuhban block, several hundred meters of limestone is present and is separately mapped. Near the south margin of the Mahalani basin, limestone of similar lithology is interbedded with sandstone. The section in the Jabal Shuhban block as described by Cole consists of two intervals, each about $70 \mathrm{~m}$ thick, of massive tan to brown limestone separated by 5 to $10 \mathrm{~m}$ of thinly bedded limestone and siltstone. Overlying these is additional thick- and thin-bedded limestone that is partly "bluishblack and black" in color.

The limestone is mostly micrite locally recrystallized to sparry calcite. Samples studied contain as much as 10 percent fine sand grains composed mostly of felsic volcanic rock fragments including devitrified shards. Plagioclase and quartz grains are also present.

Stromatolites were not found in the Jabal Shuhban block but are present at one locality (lat $25^{\circ} 42^{\prime} 27^{\prime \prime}$, long $\left.42^{\circ} 03^{\prime} 20^{\prime \prime}\right)$ where limestone is interbedded with the sandstone unit. The stromatolites described, however, are only 1 to $2 \mathrm{~cm}$ in cross-section, substantially smaller than those I observed at Jabal Farida and Jabal Damkh.

I observed limestone on Jabal Shuhban that is similar to that described by Cole. In my terms, these distinctive tan- and dark-gray-weathering limestones are identical to the limestones underlying Jabal Farida and Jabal Damkh in the south part of the Afif belt near Halaban, which have been designated as the Farida 
marble (Jackson and others, 1963). Limestone is also exposed at Jabal Kitayfah $75 \mathrm{~km}$ east-southeast of Jabal Shuhban. Several additional exposures of limestone, which have been identified as the Farida marble, are present along the east flank of the Maslum synclinorium between Jabal Kitayfah and Halaban (fig. 2; Delfour and others, 1982; Delfour, 1979).

\section{An Najady Area}

Wallace (1986) studied the lithofacies and depositional environments in part of the Murdama group in the An Najady area north of Uqlat as Suqur. He assigned these rocks to the Maraghan formation, a name introduced by du Bray (1983a). Wallace divided the Maraghan into five lithofacies and mapped them over an area of $750 \mathrm{~km} 2$; he gave no estimates of the thicknesses of these units.

The Maraghan formation in this area is composed of fine-, medium, and coarse- grained sandstone, siltstone, shale, limestone, and dolomite. Most of these rock types are present in each lithofacies, but the proportions differ. Lithofacies A (lowest) is dominantly fining-upward sequences of sandstone with lesser amounts of siltstone, shale, and carbonate rocks. Lithofacies B is dominantly siltstone and shale with lesser amounts of fine-grained sandstone and sparse carbonate rocks. Lithofacies $\mathrm{C}$ is fine-grained sandstone, siltstone, and shale with local limestone and dolomite sedimentary breccia in the western part of the area and medium and coarse-grained sandstone in the eastern part. Lithofacies $\mathrm{D}$ is fine- and medium-grained sandstone, siltstone, and shale in fining-upward sequences; sandstone is more abundant in the eastern part. Lithofacies $E$ (highest) is mainly graded sequences of fine-, medium-, and coarsegrained sandstone, siltstone, and shale.

\section{Jabal umm Sammah Section}

Jabal umm Sammah lies 18 to $23 \mathrm{~km}$ northeast of Nuqrah (pl. 2). Brosset and Delfour (1972) described the sequence of rocks on Jabal umm Sammah as follows: (1) basal conglomerate, $4,000 \mathrm{~m}$ thick, containing cobbles and boulders to $80 \mathrm{~cm}$ in size of rhyolite tuff, granite, granodiorite, and porphyritic andesite; (2) middle unit, $3,000 \mathrm{~m}$ of volcanic sandstone, tuff, siltstone, and local conglomerate; (3) upper unit, $2,000 \mathrm{~m}$ of volcanic sandstone and minor conglomerate containing pebbles of granite and rhyolite up to $5 \mathrm{~cm}$ in size. They also noted the presence of rhyolite flows and rhyolite and porphyritic andesite sills in the lower unit. Delfour (1977) assigned units 1 and 2 to the Hibshi formation and unit 3 to the Hadiyah formation. The Hibshi assignment was based on a strike projection of about $40 \mathrm{~km}$ from the end of the principal outcrop belt of the Hibshi formation.
The section I measured at Jabal Umm Sammah is $8,404 \mathrm{~m}$ thick and consists of sandstone, conglomerate, and rhyolite welded tuff (pl. 2). The lowermost $5,000 \mathrm{~m}$ of the section (units 1-9) consists mostly of conglomerate and interbedded coarse-grained sandstone. Principal cobble types are diorite, tonalite similar to that underlying the section, and minor andesite and dacite. About $400 \mathrm{~m}$ of rhyolite welded tuff (unit 8) is also present. This rock contains 1 to 2 percent each phenocrysts of quartz, K-feldspar, and plagioclase with traces of sphene in shard-textured groundmass. Above the tuff is $800 \mathrm{~m}$ of interbedded coarse- to fine-grained sandstone and $\mathrm{mi}$ nor conglomerate (units 10-15). The sandstone is greenish gray and medium gray and is identical in appearance to sandstone from the Wadi Jarir, Jabal Murdama, and other sections farther south. The uppermost 2,600 m of the section (units 16-19) consists mostly of fine-grained sandstone, locally medium or coarse grained. The finegrained sandstone, in particular, is greenish gray and resembles that in sections to the south.

The conglomeratic part of this section (units 1-9) clearly underlies strata consisting principally of sandstone (units 10-19). Are the conglomeratic strata part of the Hibshi formation? Johnson and Williams (1984) and Cole (1985) agree that the conglomerate at Jabal umm Sammah is basal Murdama and possibly should be included in the Timiriyat. Because in my view the weight of the evidence (discusssed below) points to the conclusion that the Hibshi formation is the lateral equivalent of the Murdama group, the question is moot. Basal conglomerates are locally thick and rich in boulders; examples are here at Jabal umm Sammah, the Timiriyat near Uqlat as Suqur (Cole, 1985), and at Jabal Habashi (Pallister, 1983). Elsewhere, as on Jabal Khidar (Hibshi formation sections) and at the Wadi Jarir section, they are inconspicuous.

The sandstones from the Jabal umm Sammah section are both arkosic and lithic (volcanic) arenites; many contain $\mathrm{K}$-feldspar and granite fragments despite the lack of granite cobbles or an underlying granite basement. The sandstones have well-crystallized matrices of biotite and actinolite and locally epidote and quartz. Some of the rock fragments in the framework also show the growth of secondary biotite and epidote. This biotitegrade contact metamorphism was caused by the granite adjacent to the east.

\section{Jabal as Silsilah and Jabal Saq Quadrangles}

The Murdama group underlying the Jabal as Silsilah and Jabal Saq quadrangles (du Bray, 1983a, b) forms the north part of the Maraghan basin and the northeasternmost part of the Afif belt (pl. 2, index C and D). Du Bray mapped four units in the Murdama group: the Buqaya lithic graywacke, conglomerate, Qarnayn 
lithic graywacke, and Maraghan lithic graywacke (table 4). Thin layers of metabasalt and metarhyolite underlie the Qarnayn and may be contemporaneous with the Buqaya or with pre-Murdama rocks. The named units were simplified to Buqaya formation, Qarnayn formation, and Maraghan formation for the compilation of the Jabal Habashi 1:250,000-scale quadrangle map (Johnson and Williams, 1984) and will be referred to here by these names.

Buqaya Formation

The Buqaya formation consists mostly of sandstone that is generally medium greenish gray, fine grained, and composed of poorly sorted subangular grains of quartz (30 percent), plagioclase ( 20 percent), and volcanic rock fragments (50 percent) (du Bray, 1983a). This unit, lithologically similar to the Maraghan formation described below, is distinguished by the presence of a dark tone on Landsat false-color imagery and a homogeneous aeromagnetic pattern.

\section{Conglomerate}

The conglomerate overlying the Buqaya is composed principally of clasts of fine- to medium-grained sandstone similar to the matrix of the conglomerate. A few clasts are of mafic plutonic rock, fine-grained volcanic rock, or limestone. Stretched clasts range from 2 to $25 \mathrm{~cm}$ in maximum dimension and have length-to-width ratios of $2: 1$ to $10: 1$.

\section{Qarnayn Formation}

The Qarnayn formation is texturally and compositionally varied (du Bray, 1983a). It consists mostly of sandstone, typically poorly sorted and composed of framework grains of quartz, plagioclase, $\mathrm{K}$-feldspar, and volcanic rock fragments. Matrix is largely metamorphic biotite and sericite. The unit is characterized by the local presence of pebbly to conglomeratic sandstone beds. Such beds contain well-rounded pebbles, 2 to $5 \mathrm{~cm}$ in size, of felsic to intermediate volcanic rock. High-frequency aeromagnetic anomalies are common in the area underlain by this unit.

\section{Jabal al Muwashsham Sections}

Two partial sections of the Qarnayn formation were measured at Jabal al Muwashsham (pl. 2). It is assumed that two parts of a sequence younging to the north have been measured. Total thickness of the two measured sections is $2,387 \mathrm{~m}$; I estimate that a total of at least $3,000 \mathrm{~m}$ of strata is exposed in this area.

The lower part of the measured sections consists of $1,000 \mathrm{~m}$ of very fine, fine- and medium-grained sandstone with minor interbedded siltstone (pl. 2, units $1 \mathrm{a}$, $2 \mathrm{a}$, and $1 \mathrm{~b}$ ). The middle part consists of $750 \mathrm{~m}$ of medium- and coarse-grained sandstone interbedded with minor conglomerate (units $2 b$ to $5 b$ ). Six hundred meters of very fine and medium-grained sandstone and minor siltstone constitutes the upper part (units $6 \mathrm{~b}, 7 \mathrm{~b}$ ). Pebbles in the conglomerate consist of tonalite, sandstone, and volcanic rocks.

Samples of sandstone studied all have similar composition: framework grains are 5 to 10 percent each quartz and plagioclase, 80 to 85 percent volcanic rock fragments, and 1 to 5 percent matrix.

Maraghan Formation

The Maraghan formation consists mostly of sandstone, typically brownish green to olive gray and fine grained; rocks present, however, range from mediumgrained sandstone to siltstone (du Bray, 1983a). The sandstone is poorly sorted and generally massively bedded but locally finely laminated. Framework grains consist of 50 percent volcanic rock fragments, 30 percent quartz, and 20 percent plagioclase; matrix is argillaceous. Areas underlain by this unit appear dark grayish green on Landsat false-color imagery.

Section East of Jabal as Silsilah

A section of the Maraghan formation was measured on outcrops underlying an area of low relief about $12 \mathrm{~km}$ east of Jabal Silsilah (pl. 2).

The section measured is about 7,300 m thick; however, neither top nor the base of the Murdama is exposed, and folding may have repeated parts of the section. Thus, this figure is merely suggestive of what the thickness in this area might be. The section consists almost entirely of very fine to fine-grained sandstone and siltstone. Minor medium-grained sandstone and local limy sandstone are interbedded, and a small amount of meta-andesite occurs near the top. Coarse-grained sandstone and conglomerate are absent. Because the section is more poorly exposed than most of those measured for this report, it may contain more siltstone and shale than indicated. Colors of the sandstone are medium to dark gray, locally brownish gray, rarely olive or greenish gray.

The sandstones are dominantly fine and medium grained; like their coarser counterparts elsewhere they are poorly sorted and composed of angular grains. Samples studied contain abundant lithic fragments and sparse quartz and feldspar (fig. 8).

\section{Hibshi Formation}

The Hibshi formation has been alternately placed above, in the lower part, and in the upper part of the Murdama group (Bramkamp and others, 1963; Delfour, 1977; Williams, 1983; Johnson and Williams, 1984; Cole, 1985; Cole and Hedge, 1986; this report). Because I see a close relationship between the Hibshi and other 
parts of the Murdama group, it is included therein and descriptions of some sections are given in the following paragraphs.

\section{Jabal Hibshi Sections}

Jabal Habashi, formerly known as Jabal Hibshi (pl. 2, north-central part) is the type locality for the Hibshi formation (Bramkamp and others, 1963). Sections have been measured in the northeastern and southwestern parts of the jabal.

The section in the northeastern part (Pallister, 1984 ) is about $3,200 \mathrm{~m}$ thick and consists of nine units as follows (base up): (1) lower conglomerate, (2) dacitic welded tuff, (3) volcanic sandstone, (4) dacitic welded tuff, (5) lithic wacke, (6) dacitic welded tuff, tuff breccia, lava flows, and related sedimentary rocks, (7) sandstone, siltstone, and conglomerate, (8) conglomerate, and (9) graywacke.

The section in the southwestern part (Johnson and Williams, 1984) is about $1,100 \mathrm{~m}$ thick and consists of six units as follows (base up): (1) conglomerate, (2) sandstone and siltstone, (3) sandstone, (4) conglomerate, (5) lithic tuff, and (6) lava flows and ash-flow tuffs.

Pallister (1983) pointed out that the units reported in his measured section pinch and swell rapidly along strike, some disappearing completely in a few kilometers, and that the composition of the volcanic rocks is quite varied. These factors contribute to the lack of correspondence between the Jabal Hibshi northeast and southwest sections and the Jabal Khidar section.

\section{Jabal Khidar Section}

Jabal Khidar, a southwestern extension of Jabal Habashi, is about $20 \mathrm{~km}$ long. The measured section (pl. 2) crosses the southern part of Jabal Khidar, $55 \mathrm{~km}$ due north of Uqlat as Suqur. The measured section is 4,900 $\mathrm{m}$ thick and consists mostly of medium- and coarsegrained sandstone. The basal unconformity is not exposed, but must be located under talus less than $30 \mathrm{~m}$ below the stratigraphically lowest exposure. The lowest strata exposed (unit 1) consist of $30 \mathrm{~m}$ of conglomerate; cobbles examined consist of gneissic leucotonalite (trondhjemite). This is overlain by $200 \mathrm{~m}$ (units 2,3 ) of fine-grained sandstone containing local floating pebbles in the lower part. The bulk of the section (units 4-6, $2,750 \mathrm{~m}$ ) consists of medium- and coarse-grained, mostly greenish-gray sandstone that is free of pebbles. The next $1,000 \mathrm{~m}$ (units 7-12) of the section also consists of mostly coarse-grained greenish-gray sandstone, but parts contain sparse floating pebbles or cobbles, mostly of pink tonalite. Above unit 12 is about $400 \mathrm{~m}$ of mediumand coarse-grained sandstone locally containing conglomerate (unit 13), and the top part (unit 14) is an unusual breccia composed of angular pebbles of volcanic rocks.
The sandstones in this section, like those in the others reported, consist of angular grains, poorly sorted. The compositional range of framework grains is similar to that in other sections (figs. 8, 10).

Nonconglomeratic Basal Hibshi

Ten kilometers to the northeast of the base of the Jabal Khidar section, an exposure of the sub-Hibshi unconformity and lower Hibshi strata illustrates a local variant that is free of basal conglomerate. Basement rock exposures consist of pink granite and pegmatite cut by a meta-andesite dike. Overlying this is about $100 \mathrm{~m}$ of very coarse arkosic, apparently locally derived sandstone containing some interbedded dark-grayish-red siltstone. This is overlain by grayish-red well-bedded siltstone and shale and minor ash tuff. Next, greenish and brownishgray sandstones are interbedded with the siltstone and shale; the sandstones increase in abundance upward until the rocks are identical to those of unit 2 of the Jabal Khidar section.

\section{AFIF BELT DEPOSITIONAL BASIN AND SEDIMENT SOURCES}

Evidence from the Murdama strata of the Afif belt and from adjacent pre-Murdama rocks enable tentative conclusions to be drawn regarding basin size and shape, sediment sources, and depositional environment.

\section{South Part}

The depositional basin for the Murdama group in the south part of the Afif belt appears to have been a simple elongate trough. Much of the original basin appears to be preserved, although intrusive rocks have destroyed some of the southernmost part.

The principal clue to the sediment source for the Murdama group in the south part of the Afif belt is that the bulk of the sediment was derived from silicic volcanic rocks. The geologic maps (pl. 1; Delfour, 1979, 1980) show little to no older rocks of this type to the northeast, where the dominant rocks are plutonic, ranging from granite to gabbro and metasedimentary rocks of the Abt formation. To the southwest of the Murdama outcrop belt, (Letalenet, 1979; Delfour, 1980), however, lies a belt of silicic volcanic rocks variously mapped as the Afif, An Nayzah, and Nuqrah formations. Assuming that similar volcanic rocks to the northwest have not been removed without a trace, a source for the Murdama sediments on the southwest side is indicated.

The formations named, however, appear to be inadequate in volume as a source terrane. During 
Murdama sedimentation they must have been more extensive; that is, many of the plutonic bodies shown on the maps were not unroofed to the extent that they now are, and some may not yet have been intruded. In the Afif quadrangle (Letalenet, 1979), large bodies of calcalkaline granite are mapped as post-Murdama in age but may have displaced older granite and volcanic rocks. In the Wadi ar Rika quadrangle, much plutonic "older basement" may in fact be post-Murdama granite that has displaced additional silicic volcanic rocks.

As shown above, abundant plutonic rocks were available in source areas lying to the southwest to supply the quartz, feldspar, and heavy mineral grains in Murdama sandstones. Basal conglomerate on the southwest side is mostly locally derived volcanic rock. At Jabal Raqabah, granite cobbles found at several horizons above the base may have traveled several tens of kilometers from larger bodies of granite to the southwest. Sandstones at Jabal Murdama contain more K-feldspar than most, and granite source rocks are relatively close to Jabal Murdama.

On the northeast side of the Afif belt near Halaban, clasts of diorite, quartz diorite, and tonalite in basal conglomerate are probably locally derived, as these rocks are present in the local basement. In this area, they were transported by streams flowing southwest into the basin. In the Jabal Farida section, additional conglomerate with cobbles of diorite, quartz diorite, and tonalite lies above the limestone (Farida marble), again suggesting a source to the northeast. Above this lies volcanic arenite having a probable source to the southwest.

\section{North Part}

Despite the discontinuous exposures of the Murdama outcrop areas in the north part of the Afif belt, a unified depositional basin may be reconstructed in the area shown in plate 2 . Removal of $55 \mathrm{~km}$ of net postMurdama left-lateral movement on the Halaban-Zarghat fault (pl. 2, fig. 16) would place the Murdama sandstone and conglomerate belt at Jabal Ajam opposite Jabal umm Sammah and the Jarir South basin opposite the Jarir North basin. Removal of the overlying Jurdhawiyah group (poMvs south of the Ata-Shara block, pl. 2) and the surficial deposits of Nafud al Urayq (south and east of the Jabal Shuban block, pl. 2) would leave nearly all Murdama outcrops in the area in a continuous basin broken only by post-Murdama intrusive rocks.

Although the boundary of this basin is somewhat indefinite north of lat $26^{\circ}$, pre-Murdama volcanic, sedimentary, and intrusive rocks bound much of the basin from lat $25^{\circ}$ to $26^{\circ}$, and well-exposed unconformities are present at the bases of the Wadi Jarir, Jabal Ajam, and
Jabal umm Sammah sections as well as south of the Ata fault $15 \mathrm{~km}$ east of Uqlat as Suqur. Conglomerates at these localities as well as other localities shown by Cole (1986), for example, in the Ata-Shara block, indicate proximity to basement. Limestone also occurs low in the section and locally rests on basement, thus limestone occurrences further north, such as on the Bakrah arch, suggest the proximity of basement.

A possible volcanic source terrane for the dominant volcanic debris in Murdama sandstones is located near the west edge of the map area (pl. 2; Nuqrah and Afna formations of the Hulayfah group of Delfour, 1979, 1981a), even though these rocks lie $55 \mathrm{~km}$ further northwest in the pre-Murdama reconstruction. Volcanic rocks east of Jabal Ajam, if their position is reconstructed to south of Jabal umm Sammah, may also be a significant source. Thus, the west side of the basin is the most likely source of the volcanic debris, because volcanic rocks of pre-Murdama age are not exposed on the east side, although they are present in the Ata-Shara block.

Murdama group sandstone and siltstone of the Mahalani and Maraghan basins are generally finer grained rocks than those in the rest of the Afif belt. The Qarnayn and Bu'qaya formations are mostly equally fine grained (du Bray, 1983a). Cole was apparently unable to draw a contact separating finer from coarser grained rocks in the vicinity of Uqlat as Suqur; nevertheless, fine-grained rocks are predominant over coarser sandstone and Timiriyat conglomerate. In the northeastern part of the Maraghan basin, a thick section of finegrained rocks (Maraghan formation, east of Jabal Silsilah section) overlies or is in part laterally equivalent to the rest of the Murdama. If they are a lateral equivalent, a source to the west is again indicated.

An occurrence of conglomerate north of the Raha fault, near the northeast corner of the Afit belt (pl. 2), suggests that the northeast margin of the Murdama basin is near (Cole, 1985). However, the clasts in the conglomerate are mostly sandstone similar to the matrix sandstone (du Bray, 1983a, p. 8), suggesting local reworking of lithified basin sediments. Nevertheless, a few clasts are of mafic plutonic or fine-grained metavolcanic rocks that may have been derived from local basement.

I favor the idea that the Hibshi formation exposed on Jabal Khidar and Jabal Habashi is correlative with the lower part of the Murdama group. This means that basal conglomerate and, more importantly, coarse- and medium-grained sandstone are in a position to form a basin-margin facies of coarser-grained rocks complementary to the finer-grained Maraghan, Buqaya, and Qarnayn formations within the basin. Also, Hibshi volcanic rocks are in an analogous position to basal Jarbuah basalt (Mistahjed belt of this report) and other volcanic rocks low in the Murdama section. 


\section{Triangular Diagrams}

Dickinson and coworkers (Dickinson and Suczek, 1979; Dickinson and others, 1979, 1983) developed a method for relating the composition of framework grains in sandstones to provenance and to plate-tectonic setting. The method involves determining certain grain-composition parameters based on point counts in thin section and plotting them in various combinations on triangular diagrams.

Although point counts of Murdama rocks were not made, the fields shown by estimated modes in two of Dickinson's diagrams may be significant. Plots of total quartz $(\mathrm{Q})$, total feldspar $(\mathrm{F})$, and unstable lithic fragments (L) are shown for some sections in the south part of the Afif belt and the north part of the Afif belt plus

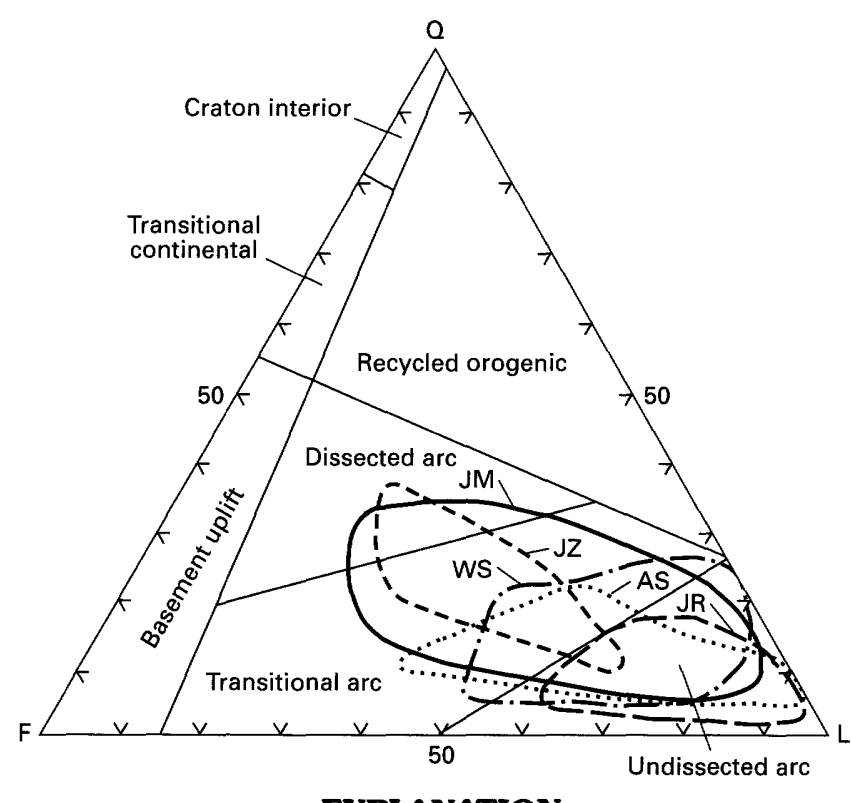

EXPLANATION

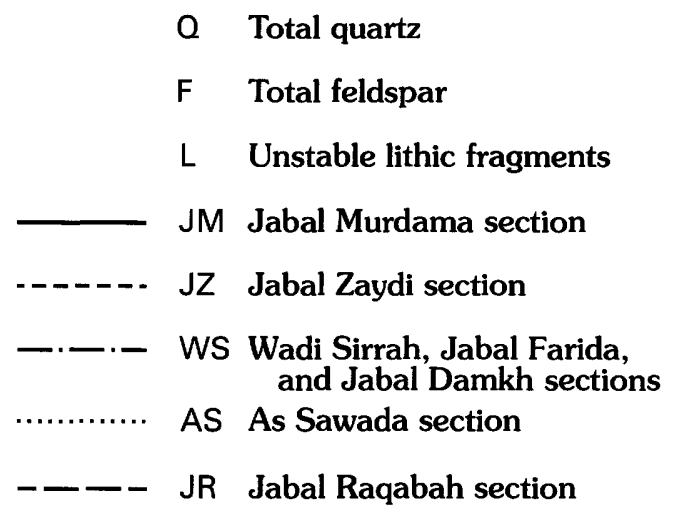

Figure 7. Triangular diagram showing estimated modes of framework grains from some sections in south part of Afif belt, in system Q-F-L (total quartz, total feldspar, and unstable lithic fragments). Diagram concept from Dickinson and Suczek (1979) and Dickinson and others (1983). the Mistahjed belt, respectively (figs. 7, 8). Plots of monocrystalline quartz $(\mathrm{Qm})$, plagioclase $(\mathrm{P})$, and $\mathrm{K}$ feldspar (K) are given for the same sections (figs. 9, 10).

The Q-F-L plots (figs. 7, 8) show the predominance of unstable lithic (volcanic) rock fragments in these rocks. They also show that the fields for the Jabal Murdama and Jabal Zaydi sections of the Afif belt and the Wadi Mistahjed section of the Mistahjed belt extend to somewhat more quartz- and feldspar-rich rocks than do the others.

Dickinson and Suczek's (1979, p. 2171) Q-F-L diagram shows that rocks of this composition originate in magmatic arc provinces, although none of the means of the suites they plotted had as large a proportion of unstable lithic fragments as do many of the Murdama rocks. Dickinson and others' $(1983$, p. 223) modified

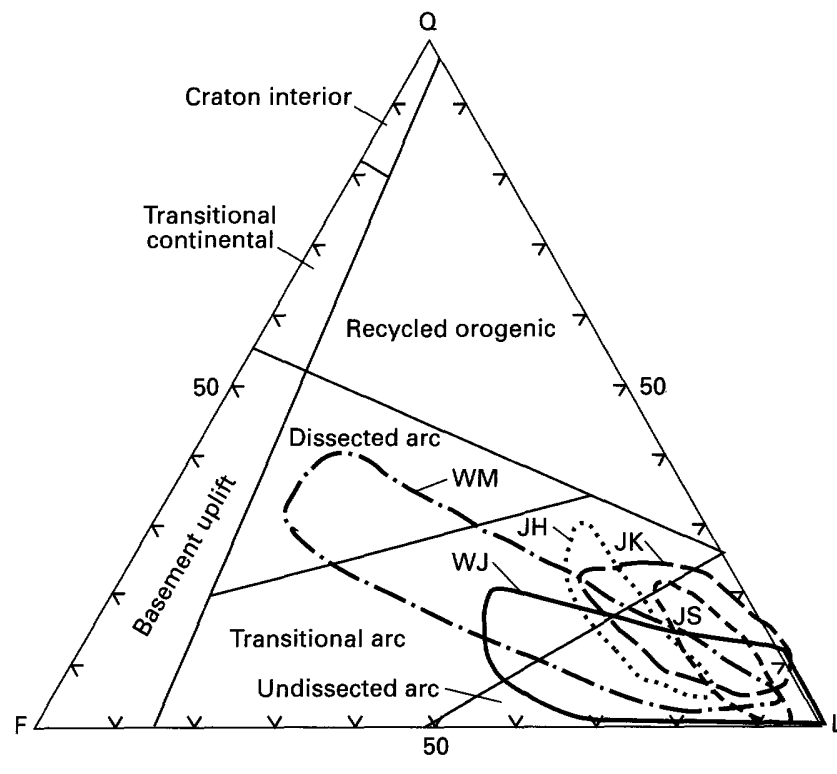

\section{EXPLANATION}

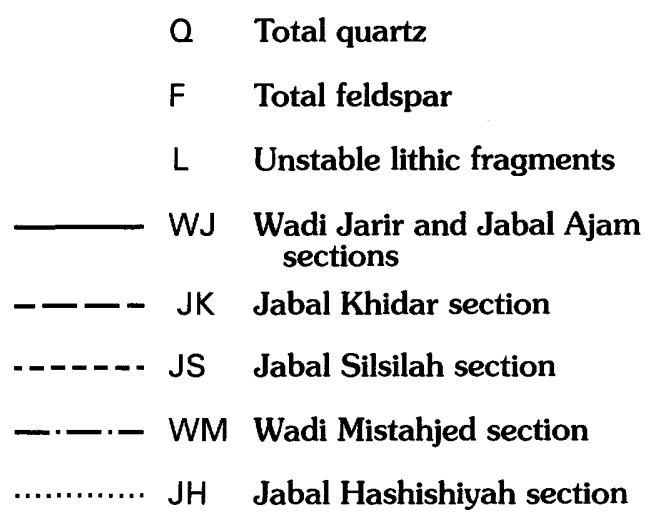

Figure 8. Triangular diagram showing estimated modes of framework grains from some sections in north part of Afif belt and Mistahjed belt, in system Q-F-L (total quartz, total feldspar, and unstable lithic fragments). Diagram concept from Dickinson and Suczek (1979) and Dickinson and others (1983). 
diagram with the same axes shows that the provenance of Murdama rocks lies in undissected and transitional magmatic arcs, although some rocks from Jabal Murdama, Jabal Zaydi, and Wadi Mistahjed extend to the field for dissected arcs. These field boundaries are plotted on figures 7 and 8.

The Qm-P-K diagrams (figs. 9, 10) show only that the Murdama rocks are generally very poor in $\mathrm{K}$-feldspar, except for the Jabal Murdama and Wadi Jarir plus Jabal Ajam sections, in which there are rocks with significant amounts. The paucity of K-feldspar may seem a curious phenomenon, as granite plutons may be expected to be associated with silicic volcanic rocks. However, Dickinson and Suzcek's (1979, p. 2172) diagram confirms what logic would dictate; that only sandstones derived from dissected magmatic arcs commonly contain much K-feldspar.

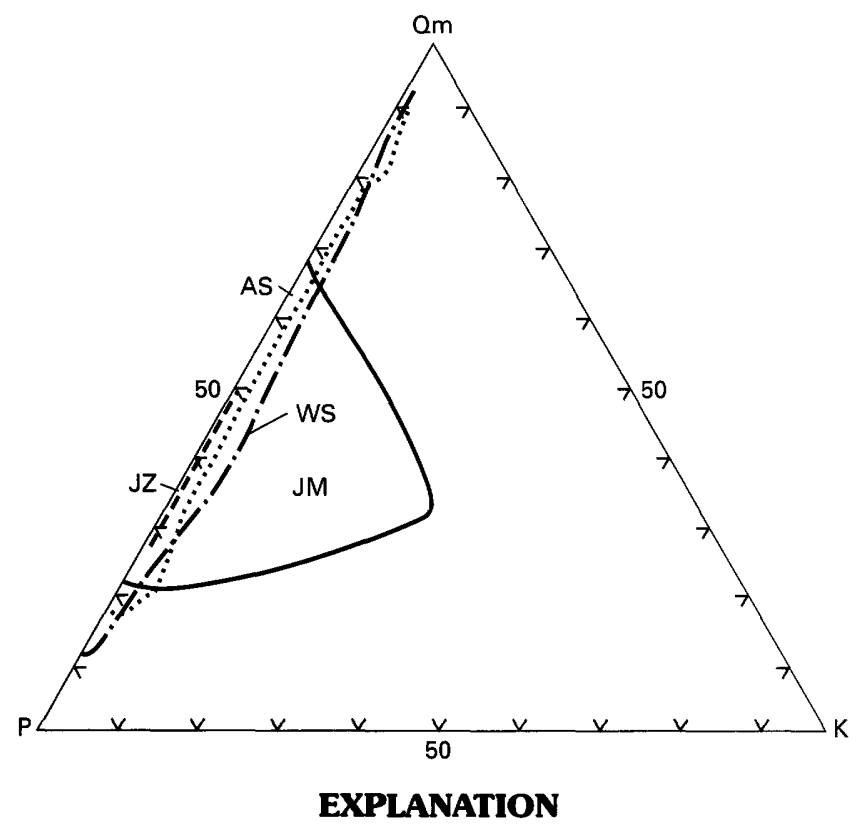

Om Monocrystalline quartz

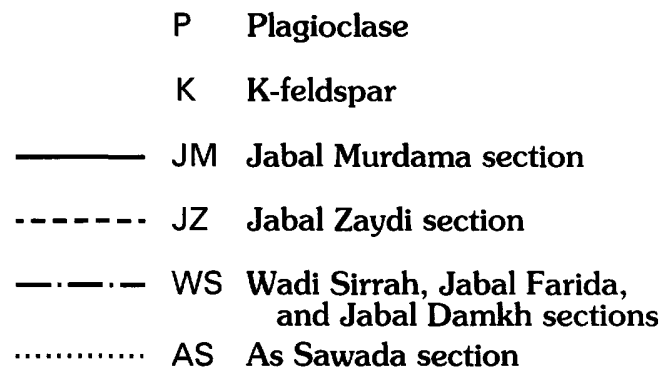

Figure 9. Triangular diagram showing estimated modes of framework grains from some sections in south part of Afif belt, in system Qm-P-K (monocrystalline quartz, plagioclase, and K-feldspar). Diagram concept from Dickinson and Suczek (1979).

\section{Environment of Deposition}

The evidence suggests that downwarp of the basin was coupled with uplift and volcanism to the southwest, which formed a high area that shed sediments rapidly. Erosion was distinctly dominant over weathering in the source area; the volcanic rocks of pre-Murdama age disintegrated to angular grains that were transported into the basin with little rounding and only moderate sorting.

Wallace and Rowley (1986) observed bedding characteristics, sedimentary structures, and paleocurrent indicators at several of the measured sections as well as other localities in the Afif belt. They observed that fining-upward sequences were common and reported many examples of cross-bedding, some with angular or tangential top and basal contacts, and some of trough type. Parting lineation, ripple cross lamination, and several

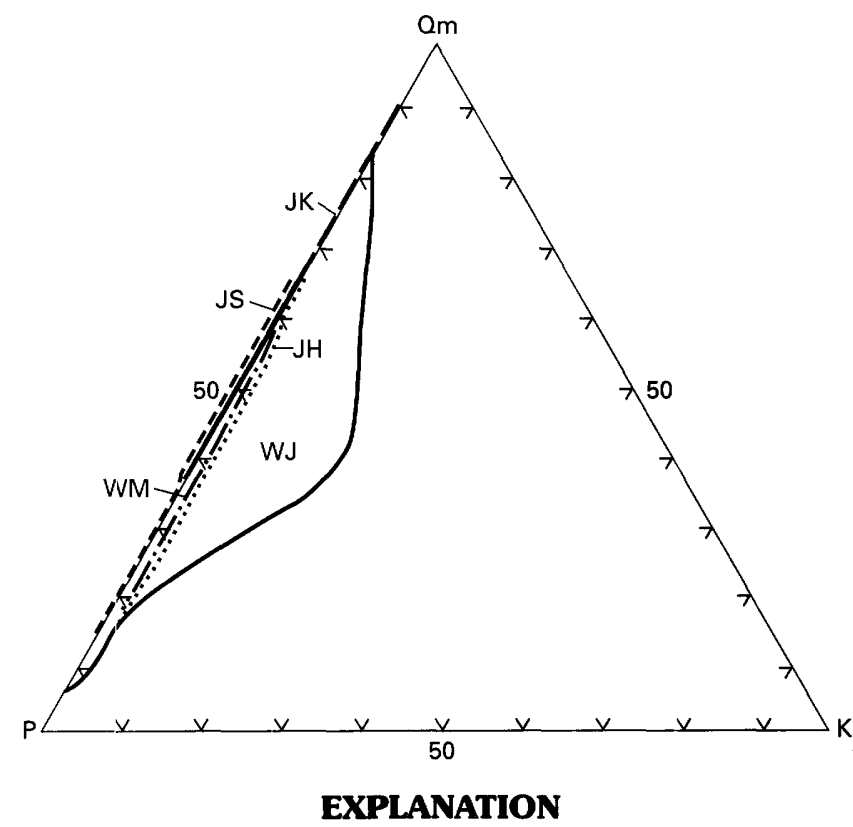

Om Monocrystalline quartz

P Plagioclase

K K-feldspar

WJ Wadi Jarir and Jabal Ajam sections

- - - JK Jabal Khidar section

....... JS Jabal Silsilah section

- - - - WM Wadi Mistahjed section

JH Jabal Hashishiyah section

Figure 10. Triangular diagram showing estimated modes of framework grains from some sections in north part of Afif belt and Mistahjed belt, in system Qm-P-K (monocrystalline quartz, plagioclase, and K-feldspar). Diagram concept from Dickinson and Suczek (1979). 
types of ripple marks were also observed. Although data are limited, most paleocurrent indicators show sediment transport to the east, southeast, or northeast in both the north and south parts of the Afif belt. Most remarkably, at Jabal Farida and Jabal Damkh, which lie on the east side of the basin, crossbeds indicate transport to the east. These observations must have been made on beds lying above basal conglomerates of obvious local derivation. These paleocurrent data agree with evidence cited above that the source area for the Murdama sediments was to the west.

Wallace and Rowley concluded that in the north part of the Afif belt, the lower part of the Murdama and the Hibshi formation are subaerial deposits. The principal evidence is the presence of dispersed framework conglomerate (conglomerate with matrix-supported clasts), which may have been deposited by mass movement or by bed-load processes in a fluvial system. In the central part of the Afif belt, conglomerate is less abundant and the rocks are generally finer grained. Wallace and Rowley believed that these were deposited on an alluvial plain, on an upper delta plain, or along a low-lying strandline. Carbonate-bank lacustrine or marine conditions prevailed in the eastern part of the basin where the Farida marble is found. For the upper part of the Murdama group, the depositional environment was inferred to be (1) a periodically submerged alluvial plain, (2) an eastward-prograding lacustrine or marine strandline, or (3) a shallow lacustrine or marine basin in which the sedimentation rate equaled the subsidence rate. Sedimentary structures such as small-scale planar and trough cross-bedding and ripple marks, which are indicative of shallow water, are the principal evidence in support of the shallow-water to subaerial environments suggested. The presence of thick welded ash-flow tuffs, particularly those at Jabal Raqabah and Jabal umm Sammah, indicate that the environment must have been locally subaerial.

While having little reason to disagree with most of Wallace and Rowley's observations, I would emphasize certain points. First, massive, planar-bedded deposits of fine-, medium-, and coarse-grained sandstone are the predominant component of the Murdama group in the Afif belt (see measured sections, pls. 1 and 2). Conglomerates, except for those near the base, and cross-bedded sandstones, are sparse. Second, fining-upward sequences are also not common. Conglomerate, both matrix-supported and clast-supported, rarely displays size grading upward into finer-grained conglomerate or granule sandstone; instead a discrete bedding parting separates conglomerate from overlying beds. Likewise, sandstone beds do not grade upward from coarse to medium to fine, but rather are characterized by poor sorting-a wide range of grain sizes-throughout. Third, siltstone and shale are sparse. Even though there is an inevitable bias toward collecting coarser rocks, many crumbly nondescript "shales" turn out to be poorly sorted very fine grained sandstones when examined in thin section.

A very thick sequence of mostly planar-bedded poorly sorted sandstone is, in my view, strongly suggestive of a prograding strandline in the form of a complex of deltas, similar to the second alternative of Wallace and Rowley, above. At Jabal Raqabah, accumulation of coarse clastic rocks suggests influx from a major stream entering the basin nearby. Elsewhere, slower sedimentation prevailed; the differences between sections on the southwest side of the basin strongly suggest the presence of several independent deltaic systems. The basin-fill pattern best fits model 3-transverse fan, transverse river, and river-dominated delta-of Miall $(1981$, p. 6, fig. 2). The North Sumatra Basin (Hamilton, 1979) is a possible modern analogue. Miall further suggested a back-arc basin as one possible tectonic setting for this type of sedimentary accumulation.

Continued sedimentation spread sand across the entire basin, a distance across sedimentary strike of more than $75 \mathrm{~km}$. In this shallow basin, topset beds must have been continuously reworked and the sediment transferred outward to broad delta fronts by slow-moving streams.

Conglomerate present near the base of the Jabal Zaydi section (pl. 1) and at the 11,500 to $13,500 \mathrm{~m}$ level in the Wadi Sirrah section represents influxes of large clasts that were apparently carried a remarkable distance across the basin (at least $62 \mathrm{~km}$ ). The clasts include volcanic rocks and granite from probable sources to the southeast; intraformational clasts of sedimentary rocks reworked from within the basin are also present.

\section{Rate of Sedimentation}

Rates of sedimentation in subsiding basins were considered by Miall (1978). The focus of his discussion is on "molasse," a term little used today that is defined as "a distinctive sedimentary facies consisting of alluvial and shallow marine deposits derived from source areas undergoing rapid uplift and erosion." As the Murdama rocks fit in this category, rates quoted are significant, although sections in foreland and successor rather than back-arc basins were studied. Rates in these basins are as high as $0.5 \mathrm{~m} / 1,000 \mathrm{yr}$. Taking the maximum thickness of Murdama sedimentary rocks, the Wadi Sirrah section, at $17.5 \mathrm{~km}$, and allowing $35 \mathrm{~m} . \mathrm{y}$. (as discussed below), this rate is seen to suffice. Miall (1978) also pointed out that rates of sedimentation in the modern Mississippi delta are an order of magnitude higher at 5 to $10 \mathrm{~m} / 1,000 \mathrm{yr}$, demonstrating the episodic nature of sedimentation. 


\section{Sources and Deposition of Volcanic Rocks}

Volcanic rocks in the Murdama group of the south part of the Afif belt are principally rhyolitic ash-fall and ash-flow tuff (Jabal Murdama and Jabal Raqabah sections) and andesite (Jabal Zaydi, Jabal Farida, and Wadi Sirrah sections). The rhyolitic tuffs may be the distal parts of large ash flows or air-fall accumulations originating in volcanoes lying to the west, in the same area as the sediment sources.

The andesite bodies must have had local sources, because they are not thick or extensive enough to have come from distant sources. Moreover, whether they are flows or sills is uncertain. Dikes of andesite are present in the Jabal Zaydi section and may mark the source of the amphibolite (meta-andesite) near the top of the section.

\section{JABAL HADHAH BELT}

Jabal Hadhah is located $95 \mathrm{~km}$ northeast of Ranyah and 130 to $155 \mathrm{~km}$ southeast of Zalm (figs. 2, 11). Rocks in this area form a separate belt of strata that may belong in the Murdama group. They lie only $140 \mathrm{~km}$ southwest across strike from the Jabal Zaydi section of the Afif belt, and $100 \mathrm{~km}$ north obliquely across strike from the northernmost part of the Murdama in the Mistahjed belt.

\section{Previous Work}

The earliest work in the Jabal Hadhah area was mapping in the 1:500,000-scale Southern Najd quadrangle by Jackson and others (1963). They correlated the limestone at Jabal Hathah (Hadhah of later authors) with the Farida marble and the sandstone and conglomerate at the adjacent Jabal Mataghah with the Halaban formation. The Farida was shown as a klippe, or remnant of a thrust sheet.

Recent work in the Jabal Hadhah area appears on the Zalm (Agar, 1984) and the Rawdah (Al Muallem and Smith, 1984) 1:250,000-scale maps. The authors of both maps correlated marble, sandstone, and conglomerate in this area with the Arfan formation, a name introduced by Hadley (1976) in the Bir Juqjuq quadrangle $100 \mathrm{~km}$ to the southwest. The Arfan was in turn placed in the newly named Bani Ghayy group. Agar divided the Arfan in the north part of the Jabal Hadhah belt into the following units (from base up): (1) volcanic and volcaniclastic rocks, (2) massive reef limestone, (3) graywacke, and (4) coarse boulder conglomerate. Agar believed that these units are in proper stratigraphic order, although most mapped contacts are faults. Al Muallem and Smith, on the other hand, described gray to green graywacke with conglomerate beds underlying a sequence of carbonate rocks in the south part of the Jabal Hadhah belt. They presented an idealized sketch section of carbonate rocks at Jabal Hadhah. The authors of both maps referred to the local presence of stromatolites (calcareous algae) in the carbonate rocks.

\section{Topography and Structure}

Jabal Hadhah (fig. 11) consists of a series of northwest-southeast-trending ridges totaling $31 \mathrm{~km}$ in length. The central part presents an escarpment slope to the west with beds dipping northeast at moderate angles, but the range as a whole is complexly folded. Jabal Matagah lies to the east adjacent to Jabal Hadhah and is underlain by sandstone and conglomerate that also mostly dip to the northeast.

\section{Sketch Section}

A traverse to erect a sketch section was made across the central part of Jabal Hadhah, and continued to the east across the southern tip of Jabal Matagah. Rocks on Jabal Hadhah consist almost entirely of both darkgray, gray-weathering and light-gray, tan-weathering limestone. Some tan-weathering limestone shows weakly developed fragmental texture; calcareous algae were not observed. Gray-weathering limestone consists of finegrained $(0.02$ to $0.1 \mathrm{~mm})$ recrystallized calcite with traces of dark interstitial material; tan-weathering limestone is very fine grained (0.01 to $0.04 \mathrm{~mm})$ and has little to no interstitial material. This limestone is identical in lithologic character to that on Jabal Farida and Jabal Damkh, 170 and $185 \mathrm{~km}$ to the northeast across the strike.

Bedding is obscure in most of the limestone at Jabal Hadhah, and gray-weathering and tan-weathering types both form massive units. A few beds contain sparse chert pebbles, and a few beds of quartz-pebble conglomerate are also present. Estimated thickness of the limestone is 500 to $1,000 \mathrm{~m}$.

To the east of Jabal Hadhah, coarse sandstone containing floating cobbles and local beds of conglomerate at Jabal Matagah and adjacent pediments appears to overlie the marble. The sandstone is greenish gray and composed of poorly sorted coarse-sand- to granule-sized angular grains that are dominantly andesite but include quartz, plagioclase, and rhyolite. Minor matrix is composed of recrystallized calcite, epidote, and chlorite. Cobbles consist of plutonic and volcanic rocks. The rocks of this sequence fine up-section to the east to medium- and fine-grained sandstone and siltstone. Estimated thickness of the exposed clastic section is 1,500 to $2,500 \mathrm{~m}$. 


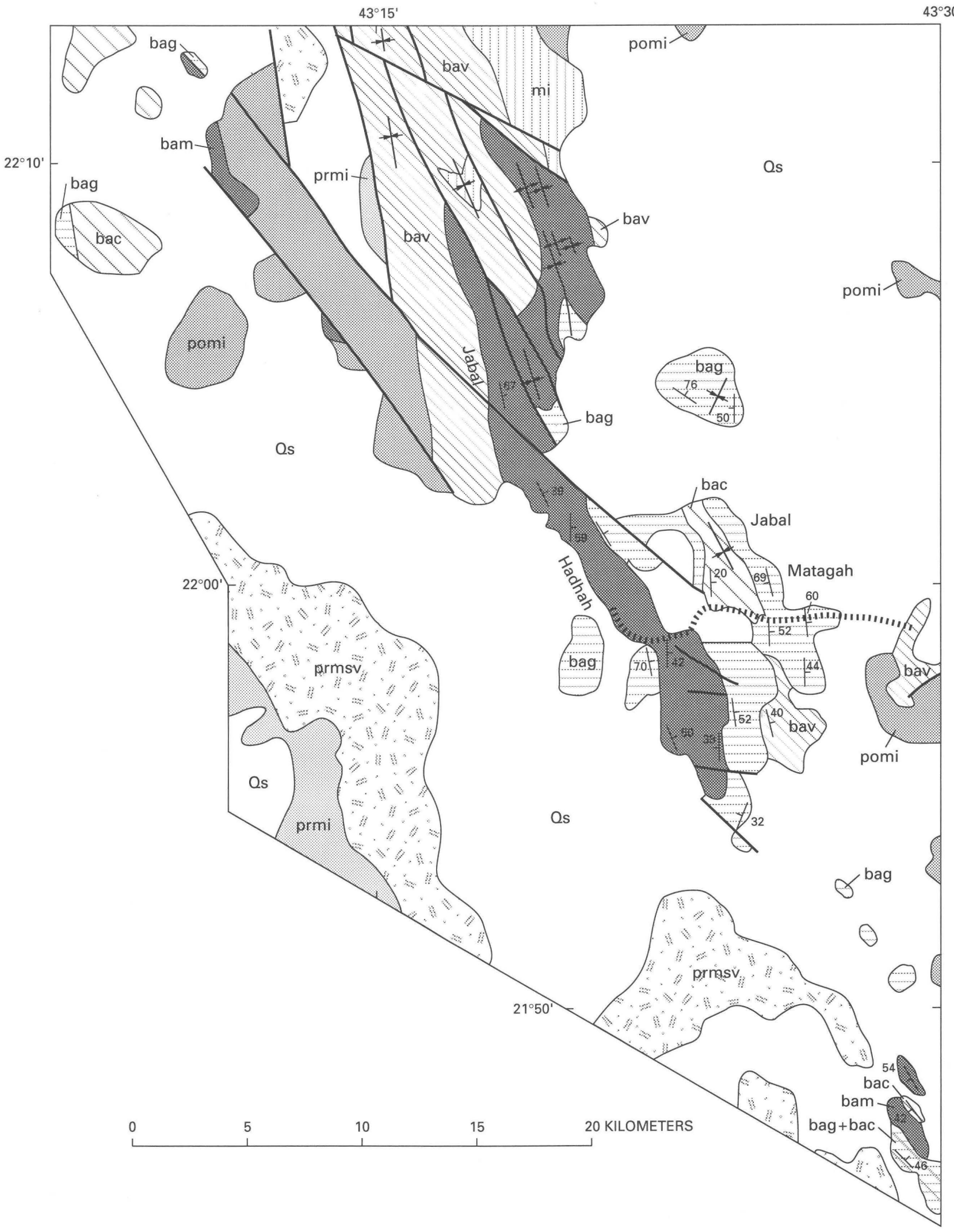

Figure 11. Geologic map of Jabal Hadhah belt, showing line of traverse. Geology adapted from 1:250,000-scale quadrangle maps: north of lat 22 ${ }^{\circ}$, Zalm (Agar, 1984); south of lat $22^{\circ}$, Rawdah (Al Muallem and Smith, 1984).
These authors placed the layered rocks in the Arfan formation (of Bani Ghayy group). Some units extended under surficial deposits. Sequence of units approximate, some overlap in age. 


\section{Discussion}

Agar (1986) believed that the Arfan formation in the Jabal Hadhah belt was deposited in a continental graben. He described two other similar grabens lying to the

\section{EXPLANATION}

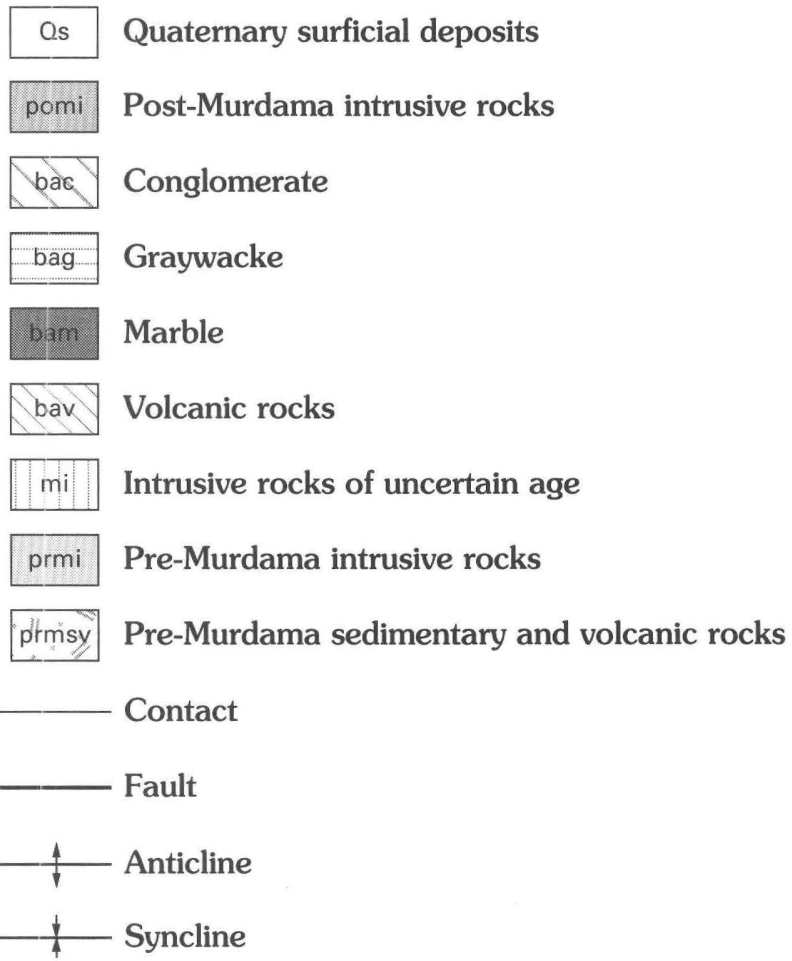

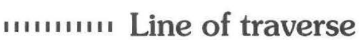

$\stackrel{67}{1}$ Strike and dip of bed

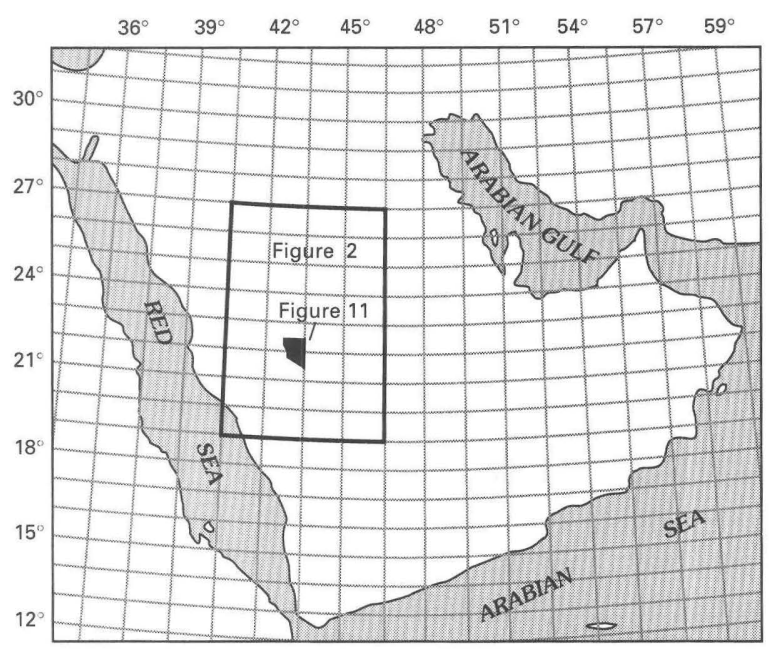

Figure 11.-Continued. west of Jabal Hadhah; these contain some similar lithologies but little limestone, and the rocks are assigned to different formations in the Bani Ghayy group.

I conclude that the stratigraphic sequence is not understood well enough in the Jabal Hadhah belt to reach any firm conclusions about the geologic history. Agar (1984, 1986), Al Muallem and Smith (1984), and I each see the section somewhat differently, as the descriptions quoted above indicate. The important fact, in my view, is that the limestone at Jabah Hadhah is identical with that at Jabal Farida, and it is apparently overlain by conglomerate and volcanic sandstone. Therefore, these rocks may be correlative with the Murdama group of the Afif belt, although deposited in a separate basin.

\section{MISTAHJED BELT}

The Mistahjed belt of the Murdama group lies to the south of the Afif and Jabal Hadhah belts and is to the southwest across the strike (figs. 2, 12). Quadrangle mapping and section measurement in this area has shown the structure to be more complex, and the stratigraphy less certain, than in the Murdama rocks from elsewhere herein described.

\section{Previous Work}

As in the Afif belt, previous work on the Murdama in the Mistahjed belt appears mostly in quadrangle maps and reports. The earliest report is the 1:500,000-scale map by Jackson and others (1963). These authors did not use the name Murdama for any rocks in the Mistahjed belt; however, limestone in several outcrop areas was included in the Farida marble.

Preparation of modern maps at 1:100,000 scale by geologists of the USGS began in 1970 and was followed by compilation at $1: 250,000$ scale. Summary remarks on the Murdama group in the 1:100,000-scale quadrangle reports follow, arranged from northwest to southeast. Table 5 summarizes the nomenclature utilized by the various authors.

In the southwest part of the Bir Juqjuq quadrangle, Hadley (1976) mapped two belts of Murdama rocks, subdivided into nine lithologic units. The belts strike northwest -southeast and lie in the midst of a major Najd fault zone (Schmidt and others, 1973; this report). The Murdama rocks are separated from adjacent rocks principally by strike-slip faults. Pre-Murdama metatonalite and other plutonic rocks lie to the southwest; to the northeast lies a broad belt of layered rocks of the Juqjuq and Arfan formations, which Hadley assigned to the Halaban group.

According to Hadley, the Murdama rocks consist of graywacke, schist, marble, and conglomerate, generally 


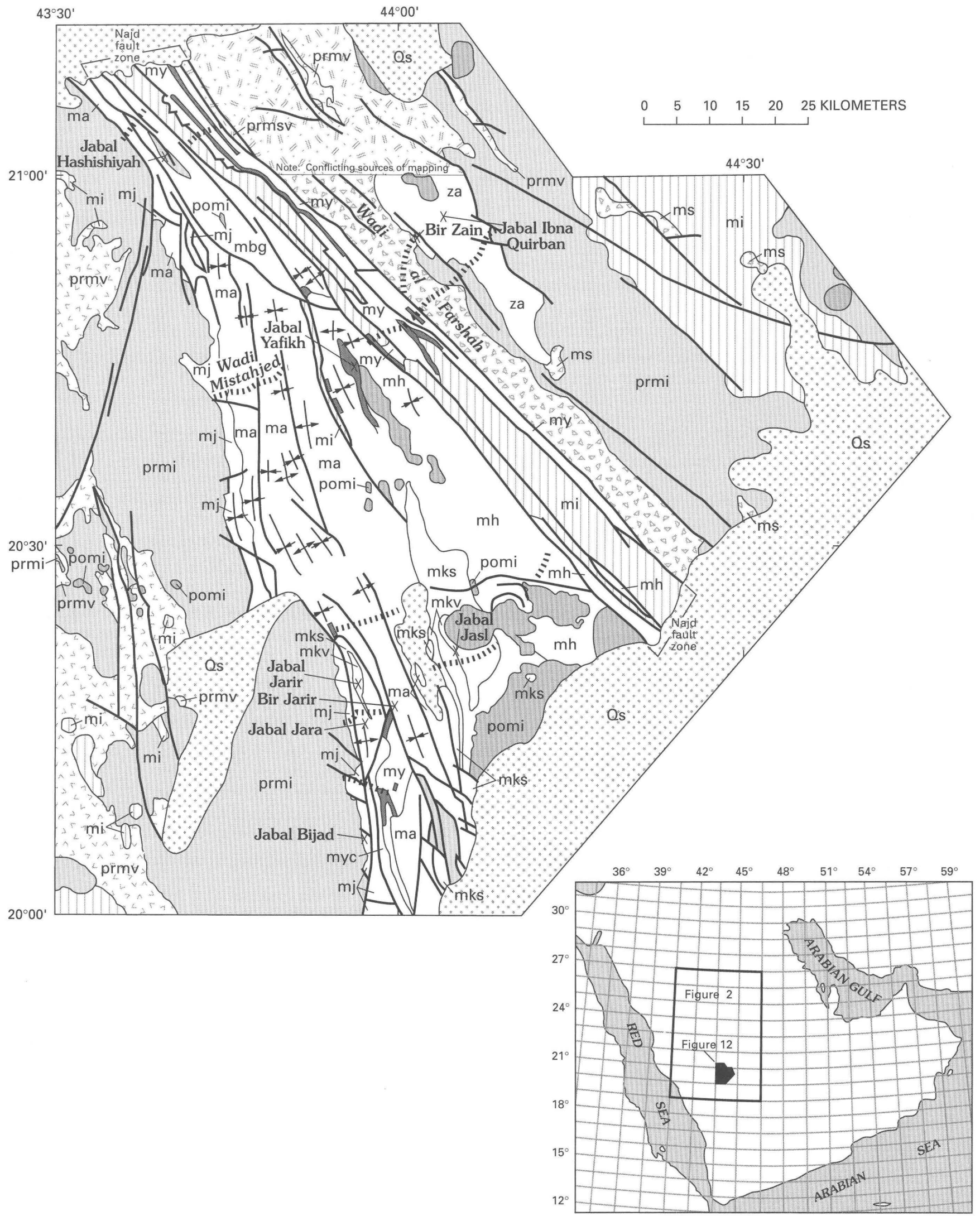

Figure 12. Geologic map of the Mistahjed belt, showing locations of sections and traverses. Geology adapted from quadrangle maps shown in index. Units of the Murdama group of Kellogg (1983) extended into Bir Juqjuq quad- rangle. Units locally extended under surficial deposits. Sequence of units approximate, many overlap in age. Relations of principal units of the Murdama group as viewed by author shown in stratigraphic diagram. 
sheared, recrystallized, and metamorphosed to low grade. The nine units are arranged in a vertical sequence in the map explanation, but Hadley stated that the stratigraphic succession is in fact poorly known.

\section{EXPLANATION}

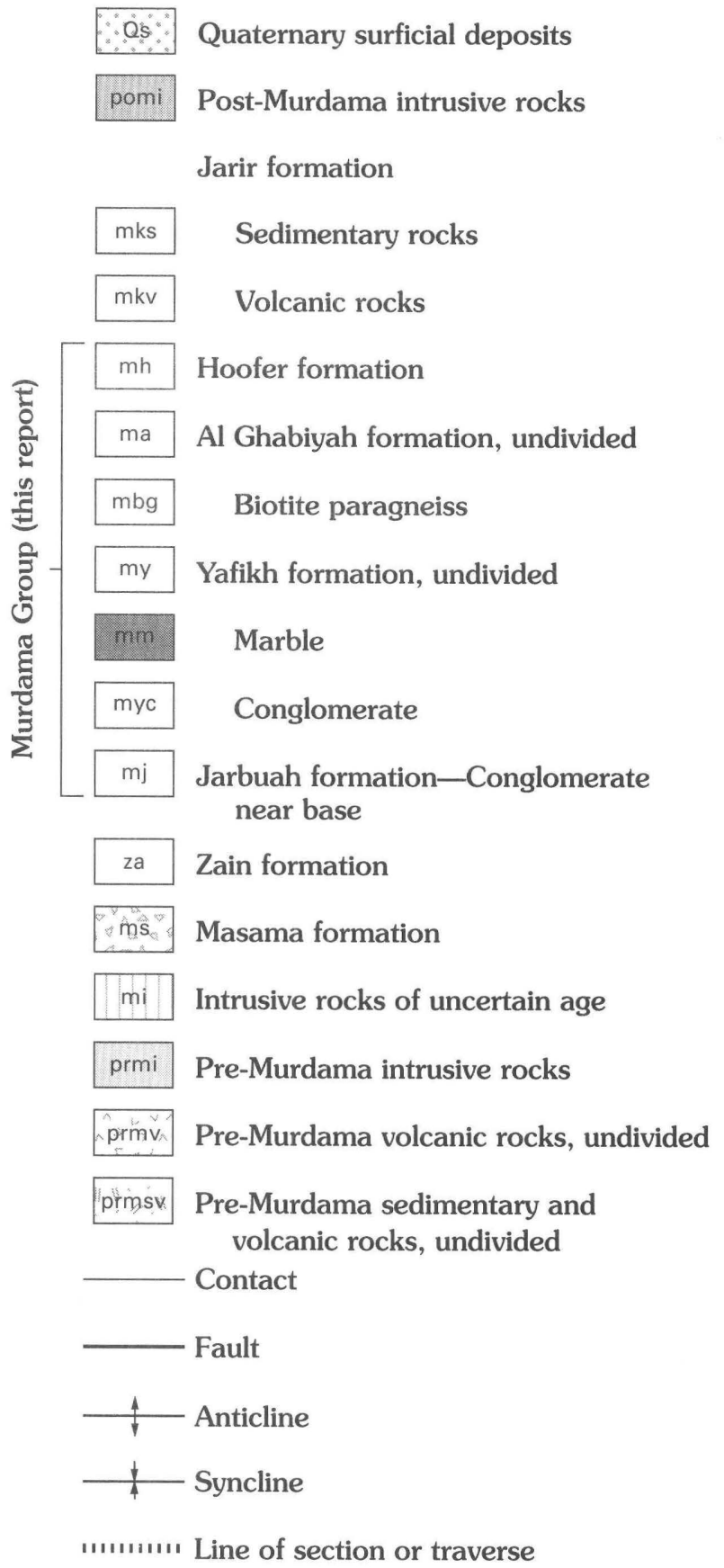

The map of the Jabal Yafikh quadrangle (Schmidt, 1981 ) includes a wealth of structural information and detailed unit descriptions. Schmidt treated the Murdama as a group and divided it into three formations (table 5),

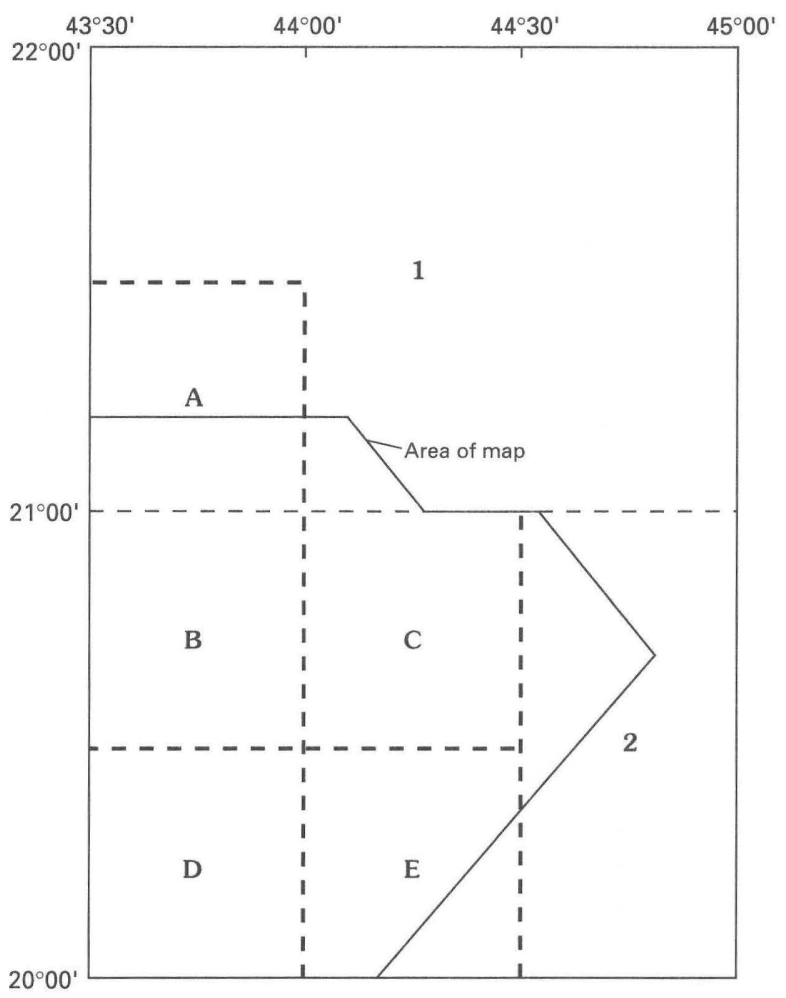

Index to 1:250,000-scale quadrangle maps, numbered; 1:100,000-scale quadrangle maps, lettered; and sources of mapping

$$
\begin{aligned}
& \text { 1. Jabal Khida; Thieme, 1985, } 1988 . \\
& \text { 2. Wadi Tathlith; Kellogg, 1983; Kellog } \\
& \text { and others, 1986. }
\end{aligned}
$$
A. Bir Juqjuq; Hadley, 1976.
B. Jabal Yafikh; Schmidt, 1981.
C. Jabal Zain; Brock, 1983.
D. Jabal Bijad; Kellogg, 1982a.
E. Jabal Jasl; Kellogg, $1982 b$.

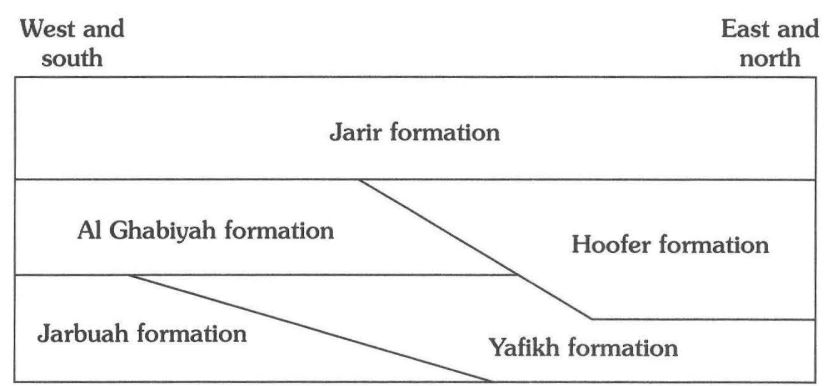

Stratigraphic diagram

Figure 12.-Continued. 
Table 5. Summary of informal unit names utilized for the Murdama group and some underlying units in quadrangle maps covering parts of the Mistahjed belt [Symbol I as in table 4 between units indicates lateral equivalence; symbol /, unit to right mostly underlies unit to left. See figure 12 for index to quadrangle maps and references]

\begin{tabular}{|c|c|c|c|c|c|c|c|}
\hline $\begin{array}{l}\text { Jabal Yafikh } \\
\text { Schmidt (1981) }\end{array}$ & $\begin{array}{c}\text { Jabal Bijad } \\
\text { Kellogg (1982a) }\end{array}$ & $\begin{array}{l}\text { Jabal Jasl } \\
\text { Kellogg (1982b) }\end{array}$ & $\begin{array}{l}\text { Jabal Zain } \\
\text { Brock (1983) }\end{array}$ & $\begin{array}{l}\text { Wadi Tathlith } \\
\text { Kellogg (1983) }\end{array}$ & This report & $\begin{array}{l}\text { Bir Juqjuq } \\
\text { Hadley (1976) }\end{array}$ & $\begin{array}{l}\text { Jabal Khida } \\
\text { Thieme (1985) }\end{array}$ \\
\hline & & & Hoofer & Hoofer & Hoofer & & \\
\hline Yafikh & Yafikh & Yafikh & Yafikh & Yafikh & & $\begin{array}{l}\text { Murdama group: } \\
\text { uppermost } 8 \text { units }\end{array}$ & $\begin{array}{l}\text { Arfan: } \\
\text { undifferentiated } \\
\text { sedimentary } \\
\text { rocks and marble }\end{array}$ \\
\hline $\begin{array}{l}\text { Al Ghabiyah- } \\
\text { biotite paragneiss }\end{array}$ & & & & $\begin{array}{l}\text { Al Ghabiyah- } \\
\text { biotite paragneiss }\end{array}$ & $\begin{array}{l}\text { Al Ghabiyah- } \\
\text { biotite paragneiss }\end{array}$ & $\begin{array}{l}\text { Hornblende, biotite, } \\
\text { and muscovite schist* }\end{array}$ & Hajizah complex \\
\hline \multirow[t]{4}{*}{ Jarbuah } & Jarbuah & Hoofer & & JarbuahlZain & JarbuahlYafikh & & \\
\hline & & Masama & Masama & & & & \\
\hline & & & Zain & & & & \\
\hline & & & & & \multicolumn{3}{|c|}{ Base of Murdama } \\
\hline
\end{tabular}

*Mapped as an older (pre-Arfan) unit in Bir Juqjuq quadrangle. Hadley later agreed with Schmidt that these rocks were the metamorphosed Al Ghabiyah formation. 
each name being derived from a locality within the quadrangle. The three formations are the Jarbuah (lowest), Al Ghabiyah, and Yafikh. Each of the formations is divided into several map units, largely on the basis of small lithologic differences. The Jarbuah formation consists of arkosic sandstone and siltstone, conglomerate containing cobbles of volcanic rocks and granite, silicic volcanic flows and tuffs, and distinctive basal basalt flows and breccias. The Al Ghabiyah formation consists principally of volcanic, arkosic, and quartz graywacke and siltstone (locally calcareous), polymictic conglomerate of volcanic clasts and local granite boulders, and rhyolite welded tuff. A schist unit in the Najd fault zone is inferred to be the metamorphosed equivalent of the $\mathrm{Al}$ Ghabiyah. The Yafikh formation contains a lower conglomerate, a middle marble unit, and an upper arkosic siltstone and sandstone unit that locally contains conglomerate and marble.

A large part of the Jabal Zain quadrangle is underlain by rocks mapped by Brock (1983) as formations of the Murdama group (table 5). These are arranged in northwest-southeast-striking belts mostly separated by faults. Brock's units are, in ascending order, volcanic member of the Zain formation, arkosic sandstone member of the Zain formation, Masama formation, Yafikh formation, Hoofer formation, and $\mathrm{Al}$ Ghabiyah formation. The Al Ghabiyah is interpreted by Brock to lie above the Yafikh, the reverse of the stratigraphic order inferred in the adjacent Jabal Yafikh quadrangle (table 5).

The volcanic member of the Zain contains intermediate and felsic volcanic flows and minor volcaniclastic rocks, whereas the arkosic sandstone member is composed of reddish-brown arkosic sandstone and minor conglomerate and volcanic rocks. The Masama formation consists of basalt and andesite flow breccia, tuff, and lahar deposits. Rocks on strike with these are assigned to the Arfan formation in the adjacent Jabal Yafikh (Schmidt, 1981) and Bir Juqjuq (Hadley, 1976) quadrangles.

The Yafikh formation is mostly marble and schist and lies in the Najd fault zone. The Hoofer formation includes graywacke, siltstone, and fine sandstone containing local conglomerate. The Al Ghabiyah formation is mostly graywacke sandstone but also contains basal conglomerate and local basalt flows.

Murdama rocks continue in a broadening belt south and southeast from the Jabal Yafikh and Jabal Zain quadrangles to the Jabal Bijad and Jabal Jasl quadrangles (fig. 12). In the Jabal Bijad quadrangle, Kellogg (1982a) extended the Jarbuah, Al Ghabiyah, and Yafikh formations in the same stratigraphic order from the Jabal Yafikh quadrangle and added the Jarir formation as a lateral equivalent of part of the Al Ghabiyah (table 5). The Jabal Jasl (Kellogg, 1982b) quadrangle map includes the same units and adds the Hoofer and Masama formations below them.
The Jarbuah formation in the Jabal Bijad and Jabal Jasl quadrangles consists principally of cobble to boulder conglomerate containing plutonic (especially granite) and volcanic clasts. Also present are arkosic and lithic arkosic sandstone and minor volcanic rocks. The $\mathrm{Al}$ Ghabiyah formation consists of graywacke, siltstone, and subordinate conglomerate. The Yafikh formation consists of conglomerate, graywacke, breccia, and local massive marble. The Jarir formation is characterized by the presence of a wide variety of volcanic rocks interbedded with sandstone and siltstone similar to that in the other units. Volcanic rocks include rhyodacite, rhyolite welded tuff, dacite, andesite, and basalt; also present are breccia and conglomerate. The Hoofer formation is graywacke sandstone and siltstone and the Masama is volcanic flows and breccias, mostly andesite, and subordinate sandstone and conglomerate.

The Wadi Tathlith 1:250,000-scale quadrangle (Kellogg, 1983) includes all of the above-mentioned 1:100,000-scale maps except Bir Juqjuq (fig. 12). Some further changes in the stratigraphic order appear on it, as indicated in table 5 .

\section{Underlying Rocks}

West of the Mistahjed belt, underlying layered rocks consist of an irregular north-south belt of andesite, paragneiss, and amphibolite (Kellogg, 1982a). Associated plutonic rocks range from gabbro and ultramafic rocks to granodiorite and monzogranite and mostly lie in a broad band between the older layered rocks and the Murdama group of the Mistahjed belt. Northeast of the Mistahjed belt lie volcanic and metasedimentary rocks variously mapped as the Masama and Zain formations (Kellogg, 1982b) and the Arfan and Juqjuq formations (Hadley, 1976). These are intruded by abundant granite and granodiorite.

\section{Structure}

The most prominent structural feature in the Mistahjed belt is a left-lateral strike-slip fault zone generally known as the southernmost Najd fault (Schmidt and others, 1973; Schmidt, 1981; Moore, 1979; Griscom, 1982; fig. 12). Displacements of as much as $165 \mathrm{~km}$ (Schmidt and others, 1979) of left-lateral movement have been suggested for this fault. Griscom (1982), however, argued for 100 to $140 \mathrm{~km}$ of movement on the basis of the offsets of magnetic anomalies and of a belt of ultramafic rocks associated with the Nabitah fault zone (fig. 2).

Within the Mistahjed belt, the Najd fault zone is 10 to $13 \mathrm{~km}$ wide. Left-lateral displacement is largely confined to the bounding fault at the northeast edge of the zone, as there is considerable similarity between the 
Table 6. Jabal Hashishiyah section A of the Murdama group

\begin{tabular}{|c|c|c|}
\hline $\begin{array}{l}\text { Unit } \\
\text { number }\end{array}$ & $\begin{array}{l}\text { Thickness, } \\
\text { (meters) }\end{array}$ & Description \\
\hline 10 & $\begin{array}{l}\text { not exposed } \\
100\end{array}$ & $\begin{array}{l}\text { Sandstone, medium-gray, very fine grained to fine grained, } \\
\text { and siltstone, medium dark gray, brown weathering }\end{array}$ \\
\hline 9 & 80 & Siltstone, medium-gray \\
\hline 8 & 130 & $\begin{array}{l}\text { Sandstone, medium- to medium-dark-gray, very fine grained, } \\
\text { fine-grained, and medium-grained; siltstone, medium-gray, } \\
\text { locally greenish }\end{array}$ \\
\hline 7 & 121 & Sandstone, olive-gray, medium-grained \\
\hline 6 & 135 & Siltstone, light- and dark-gray \\
\hline 5 & 133 & Sandstone, medium-gray, very-fine-grained \\
\hline 4 & 250 & Siltstone, medium-gray, locally thinly cleaved \\
\hline 3 & 184 & Sandstone, very fine grained, and siltstone \\
\hline 2 & 193 & Siltstone, transitional to schist \\
\hline Subtotal & 1,326 & \\
\hline 1 & $\underline{1,631}$ & Cataclastic schist, phyllite, and sandstone, with local cobbles \\
\hline \multicolumn{3}{|c|}{ Base not exposed } \\
\hline Total & $\underline{2,957}$ & \\
\hline
\end{tabular}

rocks within the zone and those lying to the southwest, whereas distinctly different rock assemblages lie to the northeast. In addition to strike-slip movement, vertical displacements are associated with gneiss antiforms within the Najd zone. Murdama sedimentary rocks have been squeezed into synforms and some have been metamorphosed to paragneiss, schist, and high-grade marble, probably during faulting (Schmidt, 1981). Faults in the pre-Murdama rocks lying to the northeast of the Najd zone are largely parallel to it and may also have some left-lateral movement. Faults in the southwest part of the area splay off the Najd zone in the north part of the Mistahjed belt and diverge on trends approximating north-south. These are high-angle faults with a largely vertical component of displacement, according to Kellogg (1983). However, their pattern suggests an additional component of left-lateral drag during Najd faulting.

Layered rocks of the Mistahjed belt are folded, and the style ranges from open to isoclinal (Kellogg, 1983). According to Schmidt (1981), pre-Murdama layered rocks near the west edge of the area depicted in figure 12 are intensely folded, probably during an event predating deposition of the Murdama.

The Murdama rocks are commonly steeply dipping, but fold axes are difficult to locate and the style of folding is commonly obscure. Some axes located by Kellogg (1982a, b), and Schmidt (1981) are shown on figure 12 . These axes are generally parallel to nearby faults, suggesting reorientation during Najd faulting. Folding mostly took place during "culminant" orogeny
(Schmidt and others, 1979) following the close of Murdama deposition, but some was earlier as shown by the presence of an angular unconformity between the Jarbuah and Al Ghabiyah formations (Schmidt, 1981a).

To the northeast of the Najd fault zone, structure in the Masama formation is obscure; however, the wellbedded Zain formation contains tight folds of simple style. These, too, are likely to have been reoriented during Najd faulting.

\section{Traverses and Sections}

A number of cross-strike traverses were made and several sections of Murdama strata measured in the Mistahjed belt, so that data on nearly all mapped units were recorded.

\section{Jabal Hashishiyah Sections}

Jabal Hashishiyah is located in the southwest part of the Bir Juqjuq quadrangle $85 \mathrm{~km}$ east-southeast from Ranyah. It is correctly named on the map of Jackson and others (1963) but mislabeled Jabal Hajizah on the Bir Juqjuq quadrangle map (Hadley, 1976). The Jabal Hashishiyah area contains the northernmost sections of rocks mapped as the Murdama in the Mistahjed belt.

Traverses were made crossing each of the two belts of Murdama rocks mapped by Hadley. The results are summarized in tables 6 and 7. These rocks are located in the Najd fault zone, hence they are sheared and in part recrystallized; the tops and bases of the sections 
Table 7. Jabal Hashishiyah section B of the Murdama group

\begin{tabular}{|c|c|c|}
\hline $\begin{array}{l}\text { Unit } \\
\text { number }\end{array}$ & $\begin{array}{l}\text { Thickness } \\
\text { (meters) }\end{array}$ & Description \\
\hline 15 & $\begin{array}{c}\text { Fault } \\
563\end{array}$ & $\begin{array}{l}\text { Sandstone, medium-light-, olive-, and greenish-gray, fine-, medium-, and coarse- } \\
\text { grained }\end{array}$ \\
\hline 14 & 10 & Limestone, medium-gray, fine-grained \\
\hline 13 & 810 & $\begin{array}{l}\text { Sandstone, light- to medium-greenish-gray and medium-olive-gray, mostly medium- } \\
\text { and coarse-grained, locally fine-grained }\end{array}$ \\
\hline 12 & 412 & $\begin{array}{l}\text { Sandstone with sparse cobbles and local interbedded conglomerate; sandstone is } \\
\text { mostly greenish-gray, coarse-grained to very coarse grained; pebbles and cobbles } \\
\text { are } 2 \text { to } 10 \mathrm{~cm} \text {, locally to } 20 \mathrm{~cm} \text { in diameter, are andesite, dacite and sparse } \\
\text { plutonic rocks }\end{array}$ \\
\hline 11 & 188 & Sandstone, medium-gray, fine-grained and siltstone, medium-gray \\
\hline 10 & 839 & Metabasalt, medium- and dark-greenish-gray, very fine grained to fine-grained \\
\hline \multirow[t]{2}{*}{9} & 58 & Siltstone, calcareous \\
\hline & 195 & Covered \\
\hline 8 & 55 & $\begin{array}{l}\text { Limestone, dark-gray, medium-grained and very light gray, fine-grained, tan } \\
\text { weathering }\end{array}$ \\
\hline \multirow[t]{2}{*}{7} & 247 & $\begin{array}{l}\text { Siltstone, medium- to dark-gray, locally greenish, much thinly cleaved, local beds to } \\
10 \mathrm{~cm} \text {; local sandstone, dark- to medium-gray and olive-gray, fine- to medium- } \\
\text { grained }\end{array}$ \\
\hline & 149 & Covered \\
\hline 6 & 140 & $\begin{array}{l}\text { Limestone, fine banding light- and medium-gray; quartzose limestone, dark-gray, } \\
\text { very fine grained; dacite, light-olive-gray, micrograined }\end{array}$ \\
\hline 5 & 106 & Limestone medium-dark-gray and white, fine-grained \\
\hline 4 & 123 & $\begin{array}{l}\text { Meta-sandstone, medium-dark- to medium-gray, fine-grained, weathers brownish } \\
\text { gray; few tens of centimeters of interbedded limestone }\end{array}$ \\
\hline 3 & 74 & Limestone, mostly white with faint banding, very fine grained \\
\hline 2 & 110 & $\begin{array}{l}\text { Amphibolite, dark-gray, fine-grained; quartz diorite gneiss, medium-dark-gray, } \\
\text { micrograined }\end{array}$ \\
\hline 1 & 34 & Limestone, locally banded in shades of light-gray, locally white, very fine grained \\
\hline \multicolumn{3}{|c|}{ Base not exposed } \\
\hline Total & 4,113 & \\
\hline
\end{tabular}

are faults, and they contain internal faults. The thicknesses of the units are only apparent thicknesses, suggestive of what the true stratigraphic thickness might be.

\section{Section A}

This section lies northwest of Jabal Hashishiyah (fig. 12, table 6) and traverses the best outcrops in the northwesternmost part of the Murdama belt. The rocks are a rather monotonous sequence of sandstone and siltstone, gray or rarely greenish, and very fine to coarse grained; they are commonly cataclasized (units 10 through 2). Conglomerate was not observed.

The rocks become more severely cataclasized down-section to the northeast, and alternating bands of more and less sheared and schistose rock are found near the contact with the schist (unit 1). The cataclastic schist, both interlayered with sandstone and in continuous section, consists of plagioclase, quartz, biotite, chlo- rite, calcite, and traces of muscovite or hornblende. It is completely recrystallized, containing no rock fragments. Its occurrence interlayered with sandstone suggests that the schist is metamorphosed Murdama sedimentary rocks, as proposed by Schmidt (1981).

A band of schist containing sparse floating cobbles is present within the schist unit (1). The cobbles are 5 to $15 \mathrm{~cm}$, locally $25 \mathrm{~cm}$, in diameter and consist of quartz and sparse syenogranite. The position of the cobble bed is different from that of the conglomerate band mapped by Hadley (1976).

\section{Section B}

The Jabal Hashishiyah section B (table 7) includes all nine of Hadley's units, separated into three packages by strike-slip faults. The section contains sandstone, siltstone, marble, sparse volcanic rocks, amphibolite, and gneiss. Units 1,3 , and 5 of the measured section consist 
of recrystallized limestone, in part pure white and in part banded in light grays. This limestone consists of very fine grained, thoroughly recrystallized calcite, subordinate tremolite, and quartz, and traces of opaque mineral. Limestone of unit 8 caps a prominent jabal; it is in part dark gray, gray weathering, and in part light gray and tan weathering. Thus the two types of limestone composing unit 8, like those at Jabal Hadhah, strongly resemble those at Jabal Farida.

Continuing up the section, there is more siltstone and sandstone, some containing sparse floating cobbles, and local beds of conglomerate. Pebbles and cobbles are locally flattened and consist of andesite, dacite, greenish siltstone, and hornblende-rich plutonic rocks. An interval of metabasalt (unit 10) has an apparent thickness of $840 \mathrm{~m}$.

The clastic rocks in this section are predominantly coarser grained than those observed in Jabal Hashishiyah section $\mathrm{A}$, which consists in large part of siltstone and very fine grained sandstone. However, the dominant clastic rocks in both sections are volcanic arenites (fig. 8), lending support to Hadley's correlation of the two belts.

\section{Correlation with Afif belt}

Most of the sedimentary rocks observed in these sections have some similarity to typical Murdama rocks of the Afif belt, despite cataclasis and a higher grade of metamorphism. Thus, they may possibly be correlative. The limestone of unit 8 closely resembles the type Farida marble; the other limestone units are similar but more strongly recrystallized.

\section{Jabal Yafikh-Bir Zain Area}

Jabal Yafikh is $125 \mathrm{~km}$ east-southeast of Ranyah and $95 \mathrm{~km}$ west-northwest of $\mathrm{Al} \mathrm{Khamsin}$. It forms a convenient reference point for sections and traverses in the northeast part of the Jabal Yafikh quadrangle (Schmidt, 1981) and the adjacent northwest part of the Jabal Zain quadrangle (Brock, 1983).

\section{Wadi Mistahjed Section}

The Wadi Mistahjed section is located directly west of Jabal Yafikh outside the Najd fault zone (fig. 12). This section is the thickest and best exposed of the Murdama rocks in the Mistahjed belt, but most attitudes are vertical or nearly so, and the section, though not obviously repetitive, is structurally complex. The section (table 8) includes parts of the two lower units of the Jarbuah formation and four, plus part of the fifth (highest) units of the Al Ghabiyah formation, as mapped by Schmidt (1981). Schmidt designated this area the type section of the Al Ghabiyah formation.

The base of the section is in fault contact with tonalite and trondhjemite of pre-Murdama age. However, $5 \mathrm{~km}$ to the northwest, a thick section of conglomerate lying unconformably on pre-Murdama intrusive rocks is well exposed (Schmidt, 1981).

The section may be summarized as follows: units 1 to 6 , mostly volcanic and arkosic arenite containing local conglomerate, $2,435 \mathrm{~m}$; units 7 to 15 , mostly volcanic arenite containing local ash tuff, $3,058 \mathrm{~m}$; units 16 to 21 , mostly graywacke sandstone and siltstone, $4,021 \mathrm{~m}$. The total thickness of $9,514 \mathrm{~m}$ is probably more than the true stratigraphic thickness because of repetition by folding. Judging from the amount of folding shown on the geologic map of the Jabal Yafikh quadrangle, the stratigraphic thickness is probably between one-third and two-thirds of the measured thickness.

The proportions of quartz and feldspar in some of these rocks are unusually large, suggesting a provenance in a dissected magmatic arc (fig. 8).

\section{Correlation with the Afif Belt}

The clastic rocks of this section are similar enough to the Murdama rocks in the Afif belt that they may be correlated. Both are predominantly volcanic arenites, although finer-grained rocks in the Wadi Mistahjed section are graywackes. The conglomerates are also similar in that they are thin, not commonly clast supported, and interlayered with sandstone.

Jabal Yafikh

Jabal Yafikh is a prominent topographic feature, rising about $400 \mathrm{~m}$ above the surrounding plains (fig. 13). It is underlain mostly by limestone of the Yafikh formation (Schmidt, 1981). The limestone is of the two distinctive types-dark gray, gray weathering and light gray, tan weathering - that are characteristic of Jabal Farida, Jabal Hadhah, near Jabal Hashishiyah, and elsewhere. Jabal Yafikh is the southernmost occurrence of this distinctive limestone.

Yafikh Northeast Traverse

The Yafikh northeast traverse starts at a point 3 $\mathrm{km}$ east of the north end of Jabal Yafikh (fig. 12) and extends northeast for $9 \mathrm{~km}$. All rocks in this area are within the Najd fault zone. The strike of the bands of differing lithology and of bounding and internal faults are all northwest-southeast. The rocks are cataclastically deformed and broken into elongate lenticular masses in a pattern even more complex than that shown on the map of Schmidt (1981).

The Yafikh northeast traverse crosses alternating bands of limestone and schist (table 9). The schists are very fine to medium grained and have textures ranging from granoblastic to cataclastic. Textures in many of the rocks are foliate, but they do not split along mica-rich parting planes as is characteristic of coarser schists. The schists contain quartz, plagioclase, micas, and other ma- 
Table 8. Wadi Mistahjed section of the Murdama group

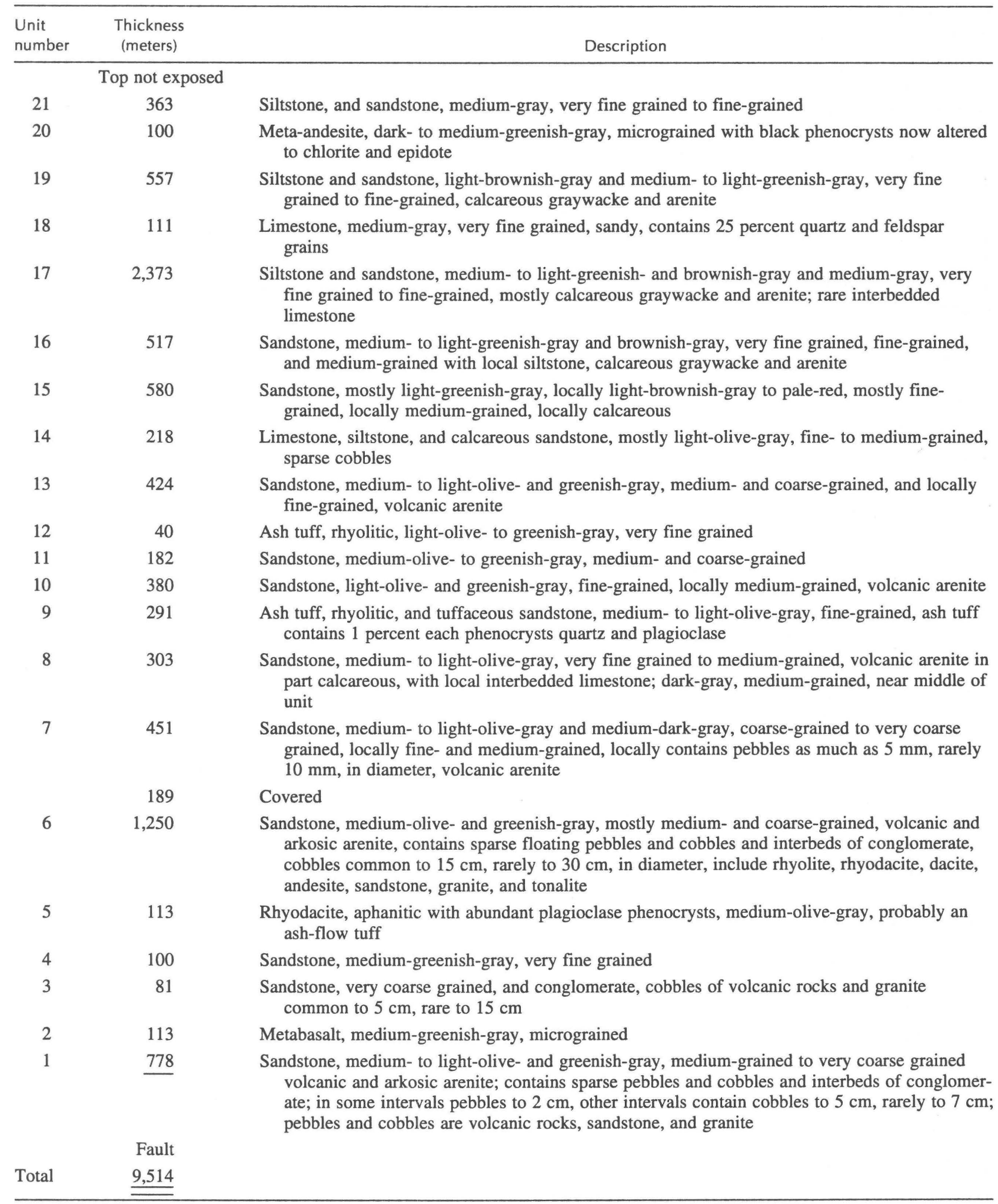

fic minerals but are so fine grained that proportions, particularly of quartz and plagioclase, are commonly indeterminate.
The limestone in this area is mostly very fine to fine grained; most has granoblastic texture, but some has elongate or aligned grains. Most is nearly 100 percent 
carbonate material, but some, notably in unit 6 , contains some secondary quartz and other minerals.

Limestone of units 8 and 10 of this traverse is on strike with that of unit 8 of the Jabal Hashishiyah northeast section and appears to be continuous with it. Thus, the distinctive color variants have been destroyed in these sheared and more highly recrystallized limestones.

Wadi al Farshah and Jabal Ibna Quirban

This area is located in the northwesternmost part of the Jabal Zain quadrangle northeast of Jabal Yafikh. Brock (1983) defined three layered rock units in this area, which from southwest to northeast are the Masama formation, the arkosic sandstone member of the Zain formation, and the volcanic member of the Zain formation (table 5), and he assigned all three to the Murdama group. Rocks of the Masama formation underlie a plain adjacent to Wadi Farshah, and those of the Zain formation underlie the mountainous area of Jabal Ibna Quirban.

The strike of these rocks is northwest-southeast parallel to the Najd faults, and Najd faults bound the belt of Masama rocks, which are, however, generally not cataclastic. Rocks of the Zain formation are deformed into open folds that plunge northwest.
Traverses to Bir Zain and Wadi Rafayah

Two traverses (not tabulated) were made across the Masama and parts of the Zain formation as mapped by Brock. Both started at the end of the Yafikh northeast section; one extends north $10 \mathrm{~km}$ to Bir Zain, the other extends northeast for $16 \mathrm{~km}$ up Wadi Rafayah.

The Masama rocks underlie a broad flat, but low hills locally provide abundant outcrops. The rocks are mostly andesitic lapilli tuff. They are colorful rocks, predominantly greenish gray, streaked and mottled in lighter and darker shades; where more oxidized, they are medium to dark brownish gray. Fragment size is commonly a few millimeters but ranges to about $1.5 \mathrm{~cm}$. Finergrained rocks grade into volcanic arenite.

The rocks contain lithic fragments with diverse textures and compositions. Most are andesite and dacite. Some rocks contain 0.5 to 2 percent plagioclase phenocrysts. A few have eutaxitic texture in the fragments or in the matrix. These characteristics suggest explosively erupted air-fall tuff with a minor ash-flow component.

The contact zone between the Masama and Zain formations is exposed near Bir Zain and in the lower part of Wadi Rafayah. Conglomerate is locally mapped

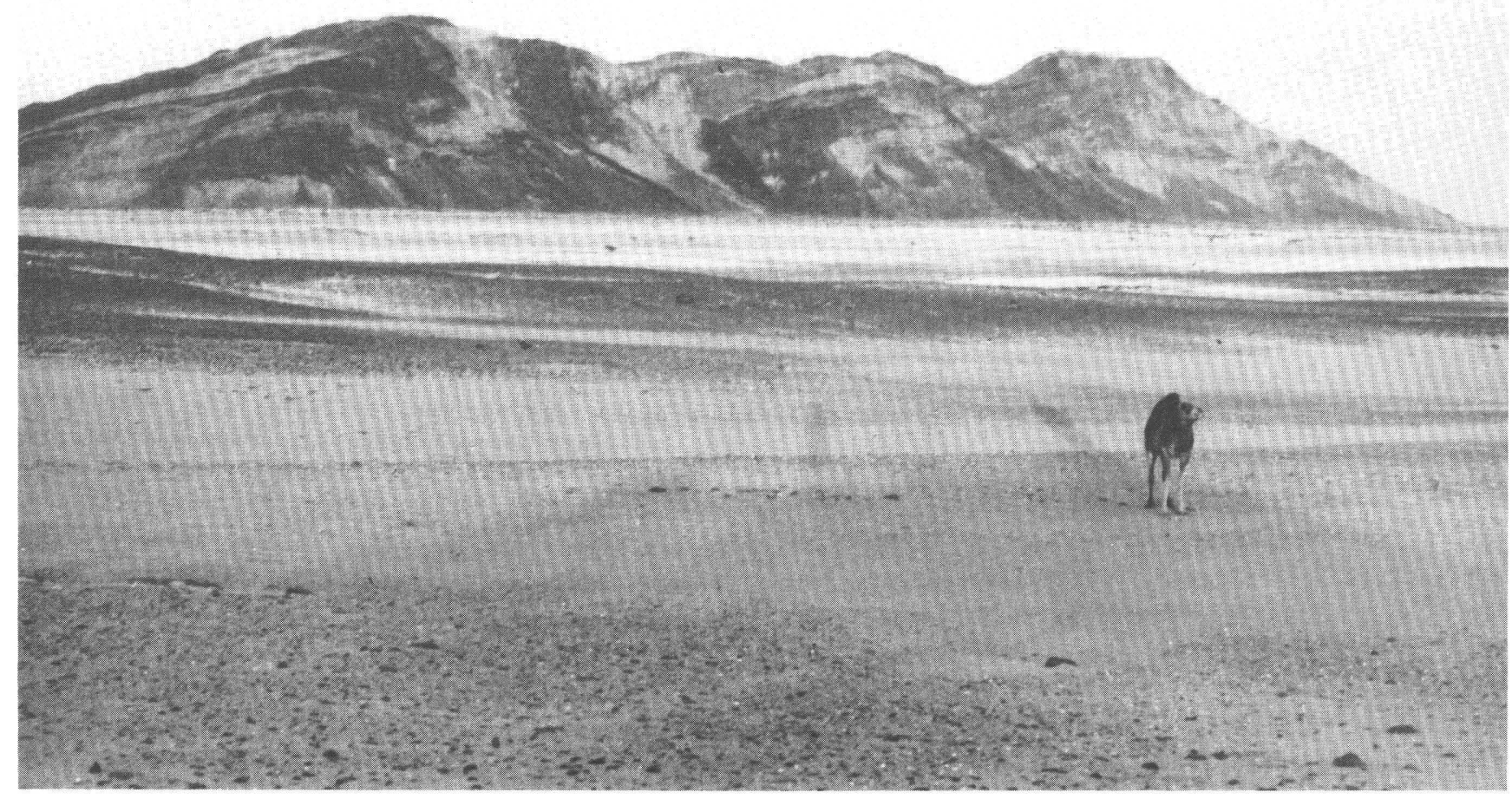

Figure 13. Jabal Yafikh from west. Tan-weathering (light in photograph) and gray-weathering (dark in photograph) limestones interlayered on jabal. Limestone is complexly folded but has overall anticlinal structure. Distance to base of jabal approximately $3 \mathrm{~km}$, and jabal approximately $400 \mathrm{~m}$ in height. Camel approximately $2 \mathrm{~m}$ at hump. 
Table 9. Descriptions of the Murdama group at the Yafikh northeast traverse

\begin{tabular}{|c|c|}
\hline $\begin{array}{l}\text { Unit } \\
\text { number }\end{array}$ & Description \\
\hline 15 & $\begin{array}{l}\text { Schist, dark- to medium-dark-gray, very fine grained to medium-grained, with strong foliation, locally mottled or } \\
\text { banded; consists of quartz, plagioclase, biotite, epidote, with minor muscovite, calcite, and opaque mineral }\end{array}$ \\
\hline 14 & $\begin{array}{l}\text { Limestone and schist, interlayered; some limestone is uniform pale pink, other is streaked and mottled white, pink, and } \\
\text { brown, very fine grained; schist is olive gray, fine grained, and consists of quartz, plagioclase, chlorite, and epidote } \\
\text { with cataclastic texture }\end{array}$ \\
\hline 13 & $\begin{array}{l}\text { Schist or mylonite, medium-dark-gray, very fine grained, consists of quartz, plagioclase, biotite, epidote with minor } \\
\text { calcite, chlorite, and opaque mineral }\end{array}$ \\
\hline 12 & $\begin{array}{l}\text { Limestone, part forms prominent outcrop line, is white or light gray, locally mottled, massive; part is medium dark gray } \\
\text { and foliate; all is very fine grained }\end{array}$ \\
\hline 11 & Limestone and schist, interlayered \\
\hline 10 & $\begin{array}{l}\text { Limestone, medium-dark- to medium-light-gray, locally brownish-gray, very fine grained to medium-grained, mostly } \\
\text { strongly foliate, locally lineated }\end{array}$ \\
\hline 9 & $\begin{array}{l}\text { Schist or mylonite, medium-gray, fine-grained, with cataclastic texture, consists of quartz, plagioclase, calcite, biotite } \\
\text { with minor hornblende, chlorite, and opaque mineral }\end{array}$ \\
\hline 8 & Limestone, medium- to dark-gray, fine-grained, locally banded, massive and foliate, locally lineated \\
\hline 7 & $\begin{array}{l}\text { Schist, medium-gray, fine-grained, strong lineation, consists of quartz, plagioclase, and hornblende with minor calcite, } \\
\text { biotite and opaque mineral }\end{array}$ \\
\hline 6 & $\begin{array}{l}\text { Limestone with minor interlayered schist, limestone is medium dark to medium light and yellowish gray, very fine } \\
\text { grained to medium grained, consists of calcite with minor quartz, biotite, muscovite, chlorite, and opaque mineral; } \\
\text { schist is medium light gray, fine grained, consists of quartz, plagioclase and minor hornblende }\end{array}$ \\
\hline \multirow[t]{2}{*}{5} & $\begin{array}{l}\text { Schist, medium- to light-gray, commonly streaked and mottled, medium-grained with strong lineation, consists of } \\
\text { quartz and plagioclase with minor biotite, muscovite, chlorite, calcite, and opaque mineral }\end{array}$ \\
\hline & Covered interval \\
\hline 4 & $\begin{array}{l}\text { Schist, medium-dark- to dark-gray and greenish-gray, very fine grained to medium-grained, consists of quartz, plagio- } \\
\text { clase, abundant hornblende and biotite, minor chlorite and opaque mineral and local garnet }\end{array}$ \\
\hline 3 & $\begin{array}{l}\text { Schist, mostly medium-gray and greenish-gray, locally pinkish-gray to pale-red, very fine grained to coarse-grained, } \\
\text { mostly with weak foliation and strong lineation, consists of quartz, plagioclase, epidote, biotite, with minor chlorite, } \\
\text { muscovite, and opaque mineral, where pinkish may contain K-feldspar }\end{array}$ \\
\hline 2 & $\begin{array}{l}\text { Limestone, medium-gray to white, locally pinkish-gray, locally banded, locally massive and white, very fine grained, } \\
\text { forms prominent outcrop line, locally foliate }\end{array}$ \\
\hline 1 & $\begin{array}{l}\text { Schist, greenish-gray, very fine grained to fine-grained, consists of quartz, plagioclase, and epidote with minor chlorite } \\
\text { and muscovite }\end{array}$ \\
\hline
\end{tabular}

here, as are elongate plutons of hornblende diorite and hornblende quartz diorite, the former believed to be post-Murdama in age and the latter pre-Murdama in age. Layered rocks of the lower part of the Zain formation in this area consist of tuff breccia, lapilli tuff, conglomerate, sandstone, and meta-andesite. Lapilli tuff, sandstone containing local pebbles, and subordinate conglomerate are interbedded. The lapilli tuff, similar to some found in the Masama, consists mostly of angular fragments of andesite of varied texture, some having abundant plagioclase phenocrysts. The sandstone is coarse-grained volcanic arenite, locally containing pebbles of volcanic rocks. Conglomerate beds contain well-rounded clasts as large as $10 \mathrm{~cm}$, rarely $25 \mathrm{~cm}$. Clasts are mostly volcanic rocks, including porphyritic andesite, dacite, and some tuff breccia; a few are pink granite. No clasts of hornblende diorite or quartz diorite were seen. Meta-andesite in this unit is medium to light greenish gray and consists of altered plagioclase and clinopyroxene phenocrysts in a groundmass of aligned altered plagioclase microlites and altered dark minerals.

Bedding attitudes shown on Brock's (1983) map indicate that this part of the section is basal to the Zain formation. The presence of interlayered tuff breccia and the clasts of tuff breccia in conglomerate, which are similar to that in the Masama, suggest that the Zain formation overlies the Masama. This is contrary to the relative ages of the units as indicated by Brock but is in agreement with the relative ages indicated along strike in the Jabal Yafikh quadrangle (Schmidt, 1981) and in the Wadi Tathlith 1:250,000-scale compilation (Kellogg, 1983).

To the northeast of the section described above lies the bulk of the arkosic sandstone member of the Zain formation (Brock, 1983). This consists mostly of very fine to coarse-grained sandstone that is a uniform medium brownish gray. Ripple marks and cross-bedding are 
characteristic features. The sandstone consists of framework grains of plagioclase, K-feldspar, quartz, and volcanic rock fragments in sparse matrix containing hematite. Proportions vary so that the rocks are either arkosic or volcanic arenites. Samples studied contained only traces to 5 percent K-feldspar; Brock reported 15 to 30 percent. The arkosic sandstone member contains subordinate interbedded volcanic rocks. Metabasalt containing altered plagioclase and clinopyroxene phenocrysts and dacite or thyodacite welded tuff containing 1 percent each plagioclase and quartz phenocrysts are found along Wadi Rafayah.

Immediately to the east of the arkosic sandstone member lies the volcanic member of the Zain formation, which consists principally of lapilli tuff as colorful as that in the Masama. The rocks consist of various combinations of pinkish, brownish, greenish, and neutral gray fragments and matrix. Fragments commonly range from 2 to $5 \mathrm{~mm}$ across, and some beds contain rounded pebbles up to $2 \mathrm{~cm}$ in diameter. Coarse- to fine-grained volcanic arenite is locally interlayed with the tuff. Like those in nearby units, the lapilli consist of andesite and dacite. The tuff also contains 1 to 20 percent plagioclase phenocrysts, trace to 2 percent quartz phenocrysts, and, locally, minor K-feldspar. Brock reported that sandstone similar to the arkosic sandstone member is interlayered with the volcanic rocks, but I did not observe this.

\section{Correlation}

There is little reason to assign the Masama and Zain formations to the Murdama on lithologic grounds. Both the Masama and the volcanic member of the Zain consist principally of lapilli tuff different from anything elsewhere in the Murdama. Likewise, the large thickness of uniform brown sandstone with ripple marks and cross-bedding, which constitutes the upper part of the Zain, is unlike anything elsewhere in the Murdama.

Removing $120 \mathrm{~km}$ of displacement on the southern Najd fault (fig. 16) places the outcrop area of the Masama and Zain formations far to the southeast, no longer facing the belt containing the Yafikh formation and the other Murdama units. Therefore, although Brock (1983) and Kellogg (1982b) found it convenient to include the Masama, Zain, and Murdama in the same package, the rocks are of different lithology and were not part of the same depositional sequence.

\section{Bir Jarir Area}

Exposures in the Bir Jarir area were studied to provide information on the Murdama group near the south end of the Mistahjed belt. Bir Jarir, a locally important well (fig. 12), serves as a reference point for sections and traverses in the northwest part of the Jabal Jasl quadrangle (Kellogg, 1982b) and the adjacent northeast part of the Jabal Bijad quadrangle (Kellogg, 1982a). Nearly all of Kellogg's map units were studied by traverses across the strike, and two measured sections were recorded.

Jabal Jasl Section

The Jabal Jasl section is located between 10 and 18 $\mathrm{km}$ northeast of Bir Jarir. Layered rocks at Jabal Jasl are mapped as the Jarir formation (Kellogg, 1982b) and are subdivided into five members. These are, from the base up, the lower volcanic member, andesite member, middle volcanic member, rhyolite tuff member, and upper volcanic member.

The measured section (table 10) includes metaandesite and basalt tuffs, flows, and breccia, conglomerate, ash-flow tuff, and metasiltstone and sandstone. The section is summarized below.

A thick lower part of the section located at the east end (units 1-7, 1,945 m) is metabasalt and meta-andesite. Units 8,9 , and 10 are interlayered sandstone, conglomerate, and metabasalt tuff. Unit 11 consists of metabasalt stretched cobble conglomerate. Units 12 through 15 are metandesite and metabasalt, in part tuffs and breccias, and unit 16 is metasiltstone. Unit 17 is boulder conglomerate having common volcanic and sparse plutonic clasts. Units 19,21 , and 23 consist of metasiltstone and some very fine grained sandstone and are interlayered with units 18,20 , and 22 , which consist of silicic tuffs, in part ash flows and breccias. Unit 24 at the top of the section consists of metasiltstone; Kellogg reported the presence of volcanic rocks, but I did not observe them.

Based on the apparent amount of folding shown on Kellogg's (1982b) map, I estimate the true thickness to be between one-third and two-thirds of the measured total of $9,362 \mathrm{~m}$.

\section{Traverse Northeast of Jabal Jasl}

A traverse lying northeast of Jabal Jasl was made to examine some of the Hoofer formation as mapped by Kellogg (1982b). The rocks were not well enough exposed to assemble the data as a measured section. The rocks found include siltstone and very fine to mediumgrained sandstone. The sandstone is volcanic arenite and the siltstone volcanic graywacke. The rocks are uniformly medium to dark greenish gray. Bedding is difficult to observe through the overprinted cleavage.

Traverse North of Jabal Bijad

A traverse (not tabulated) to study the Jarbuah and Yafikh formations of Kellogg (1982a) was made from a point near the north end of Jabal Bijad southeastward to the valley of Wadi al Qarah, and additional observations were made on a sinuous jabal located $2.5 \mathrm{~km}$ southwest of Bir Jarir. The traverse started in meta-andesite and 
Table 10. Jabal Jasl section of the Jarir formation

\begin{tabular}{|c|c|c|}
\hline $\begin{array}{l}\text { Unit } \\
\text { number }\end{array}$ & $\begin{array}{l}\text { Thickness } \\
\text { (meters) }\end{array}$ & Description \\
\hline \multicolumn{3}{|c|}{ Top not exposed } \\
\hline 24 & 422 & Covered \\
\hline 23 & 243 & $\begin{array}{l}\text { Siltstone: mostly lithic graywacke, calcareous, medium-gray, dark-gray weathering, lenticular and flaggy } \\
\text { bedding }\end{array}$ \\
\hline 22 & 151 & $\begin{array}{l}\text { Ash tuff and ash-flow lapilli tuff: ash tuff, medium-olive-gray groundmass with faint shard and pumice } \\
\text { texture and } 10 \text { percent detrital quartz; tuff breccia, dacite(?), dark-gray 1-to 3-mm fragments and sparse } \\
\text { plagioclase phenocrysts in light-olive-gray matrix, and tuff breccia, rhyolite(?), with 5-to 20-mm } \\
\text { rhyolite and andesite fragments, sparse plagioclase and local minute hornblende phenocrysts in blackish- } \\
\text { red aphanitic groundmass with eutaxitic texture }\end{array}$ \\
\hline 21 & 783 & $\begin{array}{l}\text { Siltstone, with local interbedded very fine grained sandstone: arkosic and quartz wacke, calcareous, } \\
\text { medium-dark-gray }\end{array}$ \\
\hline \multirow[t]{2}{*}{18} & 40 & $\begin{array}{l}\text { Rhyodacite tuff(?), } 20 \text { percent plagioclase and trace amounts of quartz and biotite phenocrysts in medium- } \\
\text { light-gray groundmass }\end{array}$ \\
\hline & 271 & Covered \\
\hline 17 & 217 & $\begin{array}{l}\text { Conglomerate, cobble and boulder: clasts to } 20 \mathrm{~cm} \text { common, } 30 \text { to } 50 \mathrm{~cm} \text { sparse, clasts are mostly aphyric } \\
\text { and porphyritic andesite, dacite, and rhyodacite, olive- to light-olive-gray, containing } 0 \text { to } 50 \text { percent } \\
\text { plagioclase and trace to } 1 \text { percent biotite phenocrysts, other cobbles are pink, quartz-rich granite, } \\
\text { porphyritic granite with } 1-\mathrm{cm} \text { phenocrysts of pink feldspar, and diorite(?) }\end{array}$ \\
\hline 16 & 53 & Siltstone, medium-dark-gray, and sandstone, light-brownish-gray, fine-grained \\
\hline 15 & 300 & $\begin{array}{l}\text { Andesite, dark-gray and dark-greenish-gray, aphanitic to micrograined, aphyric to porphyritic with trace to } \\
20 \text { percent plagioclase and trace quartz phenocrysts }\end{array}$ \\
\hline 11 & 947 & $\begin{array}{l}\text { Basalt stretched cobble conglomerate: round cobbles to } 5 \mathrm{~cm} \text {, stretched to } 25 \mathrm{~cm} \text {, micrograined, dusky- } \\
\text { yellow-green in dark-gray matrix and vice versa }\end{array}$ \\
\hline 10 & 1,171 & $\begin{array}{l}\text { Sandstone and basalt tuff, with local conglomerate in middle of unit: sandstone is volcanic arenite, dark- } \\
\text { gray, slightly brownish, medium- to coarse-grained; basalt tuff is medium dark gray, fine grained; } \\
\text { conglomerate composed of pebbles and cobbles to } 10 \mathrm{~cm} \text {, locally stretched, in medium-dark-gray matrix, } \\
\text { cobbles are dark-gray volcanic rocks with local alkali feldspar granite }\end{array}$ \\
\hline 9 & 225 & Conglomerate: cobbles volcanic rocks to $15 \mathrm{~cm}$, local granite cobbles \\
\hline 8 & 171 & Sandstone: volcanic or arkosic arenite, medium-dark-gray, fine- to medium-grained \\
\hline 7 & 168 & $\begin{array}{l}\text { Andesite "speckle porphyry": } 10 \text { percent light-gray plagioclase microphenocrysts in dark-gray micrograined } \\
\text { groundmass }\end{array}$ \\
\hline 6 & 101 & $\begin{array}{l}\text { Basalt conglomerate: cobbles are dark-gray aphanitic basalt and local plutonic rocks, matrix is grayish } \\
\text { yellow green }\end{array}$ \\
\hline 5 & 1,158 & Basalt and andesite, similar to units 12 and 13 \\
\hline 4 & 80 & Conglomerate: stretched clasts to $15 \mathrm{~cm}$, mostly volcanic rocks, local granite \\
\hline 3 & 88 & Basalt tuff: dark-gray, micrograined groundmass with fragments to $4 \mathrm{~mm}$ \\
\hline 2 & 168 & $\begin{array}{l}\text { Andesite "speckle porphyry": } 10 \text { percent plagioclase microphenocrysts in dark-gray micrograined ground- } \\
\text { mass }\end{array}$ \\
\hline 1 & 182 & $\begin{array}{l}\text { Sandstone, arkosic or volcanic arenite, medium-dark-gray, fine- to coarse-grained: some interlayered } \\
\text { andesite "speckle porphyry" }\end{array}$ \\
\hline \multicolumn{3}{|c|}{ Base not exposed } \\
\hline Total & 9,362 & \\
\hline
\end{tabular}


metabasalt, apparently the basement for the Jarbuah formation. Clasts of similar rocks appear in the overlying conglomerates.

The lower part of the Jarbuah consists mostly of conglomerate, characterized by the presence of subangular fragments of dark-gray volcanic rocks and rounded clasts of coarse-grained pink granite and subordinate tonalite and diorite. Sizes and abundances of clasts vary substantially from layer to layer. Volcanic fragments commonly range in size from 1 to $10 \mathrm{~cm}$, locally to $25 \mathrm{~cm}$. Plutonic clasts commonly range from 2 to $10 \mathrm{~cm}$, but some are as large as $2 \mathrm{~m}$. In some layers, the larger clasts are matrix supported and constitute $25 \%$ or less of total volume; in others the clasts are close packed. Matrix is medium- to coarse-grained greenishgray sandstone, commonly with 1- to 4-mm fragments of pink feldspar. Interlayered with the conglomerate is meta-andesite tuff, locally containing sparse large clasts of volcanic or plutonic rocks. Light-brownish-gray dacite(?) tuff breccia is also locally interlayered.

The upper part of the Jarbuah consists of the same types of rocks, but clast sizes are generally smaller. Volcanic rock fragments range commonly from 2 to $5 \mathrm{~mm}$, rarely to $2 \mathrm{~cm}$, and plutonic clasts are commonly 0.5 to $3 \mathrm{~cm}$, rarely to $10 \mathrm{~cm}$. Partly disintegrated granite clasts are a characteristic feature.

A small outcrop area of the upper part of the Yafikh formation was observed at the southeast end of this traverse. The rock is conglomerate containing subrounded pebbles of volcanic rocks, mostly $1-2 \mathrm{~cm}$, locally $15 \mathrm{~cm}$ in size, in coarse-grained greenish-gray sandstone matrix. Granitic clasts are absent.

Also examined on this traverse were several jabals in the Wadi Qarah valley between 2 and $12 \mathrm{~km}$ south of Bir Jarir, mapped as the lower part of the Yafikh formation by Kellogg (1982a). These jabals all consist of limestone, commonly striped or mottled in light to dark gray or grayish black. Breccia texture is common; fragment size is commonly a few centimeters but locally measurable in meters. Grain size is generally very small, commonly 0.02 to $0.1 \mathrm{~mm}$. As with carbonate rocks elsewhere in the Murdama, the microtexture is that of recrystallized spar. This limestone is similar in color and texture to the more metamorphosed limestones near Jabal Hashishiyah and northeast of Jabal Yafikh; the distinct tan- and gray-weathering types characteristic of the limestone at Jabal Farida are absent.

\section{Section North of Jabal Jarir}

Layered rocks in the northeasternmost part of the Jabal Bijad quadrangle were mapped as the Yafikh and Al Ghabiyah formations by Kellogg (1982a). A traverse to obtain additional data on these formations was made across the strike of their principal belt of outcrop and is described from the lowest exposure at the point $8 \mathrm{~km}$ north of Jabal Jarir to a point $10 \mathrm{~km}$ to the northeast (14 $\mathrm{km}$ north of Bir Jarir). Exposures for part of the traverse were good enough to record as a measured section (table 11).

The lowest unit of the section (unit 1) consists of limestone and is mapped as part of the Yafikh formation (Kellogg, 1982a). The limestone is micrograined and has banded and breccia textures identical to those in limestone underlying jabals in the Wadi Qara valley (traverse north of Jabal Birjad).

The main part of the section (units 2-12) consists of sandstone, siltstone, pebbly sandstone, and cobble conglomerate, all dominantly greenish gray in color. These rocks are mapped as the $\mathrm{Al}$ Ghabiyah formation (Kellogg, 1982a). Units 13 and 14 are conglomerate containing pebbles and angular fragments of volcanic rocks. They are shown on the map of Kellogg (1982a) as the Yafikh formation, but $\mathrm{I}$ include this area in the $\mathrm{Al}$ Ghabiyah formation (fig. 12) because the rocks are similar to those in the Al Ghabiyah elsewhere, and no distinct Yafikh lithologies such as limestone appear.

The thickness calculation for the part of the $\mathrm{Al}$ Ghabiyah formation that is sufficiently well exposed to measure is about $3,500 \mathrm{~m}$. This was obtained over about two-thirds of the outcrop width, implying a total thickness of about $5,250 \mathrm{~m}$. However, folds and faults are mapped in this area (Kellogg, 1982a), and this figure is probably a maximum and merely suggestive of what the true thickness might be.

\section{Jabal Jara Traverse}

The final traverse in this area (not tabulated) extends from a base $7 \mathrm{~km}$ due west of Bir Jarir eastward across Jabal Jara nearly to Bir Jarir. It crosses the lower part of the Jarbuah formation and the volcanic and sandstone member of the Jarir formation as mapped by Kellogg (1982a).

At the western end of the traverse, rocks probably underlying the Murdama are plutonic breccia consisting of fragments of meta-andesite or microdiorite in a matrix of tonalite.

The basal part of the Murdama (lower part of the Jarbuah formation) consists mostly of conglomerate or tuff breccia containing angular fragments of dark-gray volcanic rocks up to $1 \mathrm{~cm}$ in size and rounded clasts of granite up to $10 \mathrm{~cm}$. Some of the granite clasts were disintegrated at the time of deposition to angular fragments and individual mineral grains, as in the upper part of the Jarbuah formation in the traverse north of Jabal Bijad. Matrix is light-olive to greenish-gray unsorted sandstone; the finer grains are mostly andesite. Similar sandstone, locally containing floating volcanic and granite clasts, is interbedded with the conglomerate.

Across a fault lies a band of rocks mapped as the Jarir formation. Kellogg's (1983a) map shows the rocks 
Table 11. Section of the Murdama group north of Jabal Jarir

\begin{tabular}{|c|c|c|}
\hline $\begin{array}{l}\text { Unit } \\
\text { number }\end{array}$ & $\begin{array}{l}\text { Thickness } \\
\text { (meters) }\end{array}$ & Description \\
\hline & p not expos & \\
\hline 14 & & $\begin{array}{l}\text { Conglomerate, subangular volcanic rock fragments } 5 \text { to } 10 \mathrm{~cm} \text {, greenish- and brownish-gray clasts in } \\
\text { light-greenish-gray matrix of andesite tuff }\end{array}$ \\
\hline 13 & & $\begin{array}{l}\text { Conglomerate, pebbles of grayish-yellow-green volcanic rocks in darker greenish-gray matrix and } \\
\text { vice versa, pebbles commonly to } 3 \mathrm{~cm} \text {, locally to } 10 \mathrm{~cm} \text {; matrix is andesite tuff, some contain } \\
\text { dark-gray angular fragments } 0.5 \text { to } 5 \mathrm{~mm}\end{array}$ \\
\hline 12 & & $\begin{array}{l}\text { Sandstone or tuff, greenish-gray, irregular fine- to medium-grained, sparse local pebbles of volcanic } \\
\text { rocks }\end{array}$ \\
\hline 11 & 474 & Sandstone, dark-greenish-gray, very fine grained \\
\hline 10 & 404 & $\begin{array}{l}\text { Sandstone, with local interbedded conglomerate: sandstone, poorly sorted, medium-grained with } \\
\text { coarse grains, volcanic arenite with dominant grains silicic volcanic rocks, olive-gray, locally has } \\
\text { distinct bedding, darker beds } 1-3 \mathrm{~mm} \text {, lighter beds } 1-3 \mathrm{~cm} \text {; conglomerate, subrounded pebbles } \\
\text { greenish- and brownish-gray volcanic rocks to } 1 \mathrm{~cm} \text { in matrix of sandstone similar to above }\end{array}$ \\
\hline 9 & 381 & $\begin{array}{l}\text { Sandstone, medium-greenish-gray, very fine grained and fine-grained, bedding faintly visible, local } \\
\text { lenses of brownish-gray siltstone (shale chips?) } 2-3 \mathrm{~cm} \times 2-5 \mathrm{~mm}\end{array}$ \\
\hline 8 & 380 & Sandstone and local conglomerate, greenish-gray, highly deformed and irregular \\
\hline 7 & 413 & $\begin{array}{l}\text { Sandstone, and local pebbly sandstone: sandstone, olive-gray, fine- and medium-grained, local faint } \\
\text { bedding, volcanic arenite with dominant grains of silicic volcanic rocks; pebbly sandstone, } \\
\text { medium- to coarse-grained with pebbles of greenish- and brownish-gray volcanic rocks to } 1 \mathrm{~cm} \text {, } \\
\text { local pebbles of granitic rocks }\end{array}$ \\
\hline 6 & 625 & $\begin{array}{l}\text { Sandstone, brownish-gray, poorly sorted, medium-grained with coarse and very coarse grains and } \\
\text { granules, volcanic arenite with dominant grains of silicic volcanic rocks; interbedded pebbly } \\
\text { sandstone, similar to above but contains angular fragments } 0.5 \text { to } 1 \mathrm{~cm} \text { and sparse rounded pebbles } \\
\text { to } 5 \mathrm{~cm} \text {, mostly volcanic, rarely granitic, rocks, beds } 4-10 \mathrm{~cm}\end{array}$ \\
\hline 5 & 579 & $\begin{array}{l}\text { Siltstone, light-greenish-gray, volcanic arenite (dominant grains of silicic rocks?) in part finely } \\
\text { laminated with } 2 \text { - to } 4-\mathrm{mm} \text { darker beds between } 5 \text { - to } 20 \text {-mm lighter beds }\end{array}$ \\
\hline 4 & 243 & $\begin{array}{l}\text { Conglomerate, brownish-gray matrix with pebbles of volcanic rocks and quartz with rare granitic } \\
\text { rocks mostly } 0.5 \text { to } 2 \mathrm{~cm} \text {, sparse cobbles to } 10 \mathrm{~cm} \text {, local interlayered siltstone }\end{array}$ \\
\hline 3 & & $\begin{array}{l}\text { Cobble conglomerate with local interbedded sandstone: conglomerate contains clasts of volcanic and } \\
\text { plutonic rocks to } 20 \mathrm{~cm} \text {, rarely to } 40 \mathrm{~cm} \text {, sandstone is greenish-gray, medium- and coarse-grained } \\
\text { volcanic arenite with silicic and andesitic fragments; forms rough, knobby outcrops similar to } \\
\text { conglomerate in Jabal Jasl section }\end{array}$ \\
\hline 2 & & Sandstone, brownish-gray, very fine grained, or siltstone, brownish-gray, locally finely laminated \\
\hline 1 & & $\begin{array}{l}\text { Limestone, medium-light-gray with faint banding } 1-3 \mathrm{~mm} \text {, micrograined, last outcrops forming ridge } \\
\text { are limestone, medium-light-gray to very light gray, locally brownish, micrograined with sedimen- } \\
\text { tary breccia texture }\end{array}$ \\
\hline
\end{tabular}

Fault

to be folded, but repeated units were not identified in this traverse. The rocks are described in units from west to east, but the stratigraphic order is uncertain.

Unit 1 consists of poorly sorted greenish-gray volcanic arenite containing dominant silicic volcanic rock grains. Unit 2 is rhyodacite, probably flows, containing 1 percent plagioclase phenocrysts in dark-gray to slightly brownish aphanitic groundmass. Unit 3 crops out on Jabal Jara itself and consists of cataclastic volcanic arenite, dark gray to dark brownish gray and composed mostly of andesite grains. Unit 4 consists in part of cobble conglomerate containing angular fragments 0.5 to $2 \mathrm{~cm}$ in size and rounded clasts up to $20 \mathrm{~cm}$; all clasts are volcanic rocks. Matrix is unsorted volcanic arenite with dominant andesite grains. Interbedded sandstone is greenish-gray andesite-dominant volcanic arenite, locally containing floating pebbles of volcanic rocks 0.5 to $2 \mathrm{~cm}$ in size. Unit 5 consists mostly of conglomerate or breccia composed of angular fragments of volcanic rocks mostly 0.5 to $2 \mathrm{~cm}$ in size in matrix of medium-darkgray unsorted volcanic arenite with dominant andesite grains. Fine-grained greenish-gray sandstone and duskyyellow green siltstone are interbedded. Unit 6 consists of conglomerate containing volcanic rock fragments commonly up to 5 , locally up to $15 \mathrm{~cm}$ in size; matrix is greenishgray volcanic arenite with dominant andesite grains. 


\section{Stratigraphic Order and Correlation}

The stratigraphic order of many of the rock units in the Mistahjed belt remains uncertain. Changes have been made between compilation of the 1:100,000-scale and the 1:250,000-scale maps and between those maps and this report. Authors also differ as to whether or not certain units should be assigned to the Murdama group (table 5).

The Jarbuah formation is clearly the oldest unit in the western part of the belt. Near Jabals Jarbuah, Bijad, and Jarir it lies with distinct, commonly angular unconformity on older rocks. The Al Ghabiyah formation overlies the Jarbuah along many kilometers of contact in the Jabal Yafikh quadrangle (Schmidt, 1981) and is the thickest and most extensive part of the Murdama group in the belt. The Hoofer is mostly in fault contact but is logically placed above the Al Ghabiyah as the section continues to young to the northeast, but the Hoofer may be at least in part a lateral equivalent of the $\mathrm{Al}$ Ghabiyah. .

The rock sequences containing carbonate beds and lenses have been assigned to the Yafikh formation (Schmidt, 1981; Kellogg, 1982a, b), but the stratigraphic position of these rocks is quite uncertain. In the northeast part of the belt, the Yafikh formation occurs mostly in tectonic slices in the Najd fault zone; other outcrops near Jabal Yafikh have mostly fault contacts with the Al Ghabiyah formation and uncertain relationships with the Hoofer. However, carbonate-bearing rocks correlated with the Yafikh formation are mapped overlying the Al Ghabiyah in the south part of the area, east of Jabal Bijad (Kellogg, 1982a).

In the Afif belt, conglomerate and limestone commonly both occur near the base of the section. This is true at Jabals Farida and Damkh, and Cole (1985) pointed out that this association is common in the north part of the Afif belt as well. Rock sequences in the Mistahjed belt containing limestone all can be interpreted to lie low in the Murdama section. Limestone and conglomerate east of Jabal Bijad (fig. 12; Jabal Bijad traverse) may overlie thick conglomerate of the Jarbuah, and the contact, mapped by Kellogg showing the Yafikh overlying the Al Ghabiyah, may be faulted or overturned. Limestone north of Jabal Jarir (section north of Jabal Jarir) lies near the base of the section. Limestone in the Najd fault zone (Yafikh northeast traverse) is all tectonically disturbed and of unknown stratigraphic position. No strata belonging to the Jarbuah or other underlying units are mapped here, and a position low in the section provides an interpretation of the structure involving only moderate stratigraphic displacement on the Najd fault zone.

Limestone also overlies conglomerate at Jabal Yafikh and at localities immediately to the west. These occurrences are here interpreted as lying low in the section, and they are overlain by finer-grained clastic rocks of the Hoofer formation (Kellogg, 1983). A sketch facies diagram attached to figure 12 illustrates these relations.

The Jarir formation was interpreted by Kellogg (1983) to overlie the Al Ghabiyah and Hoofer formations in the center of the area and therefore to be at the top of the layered sequence. In his interpretation, the Jarir remains part of the Murdama group. However, because the rocks composing the Jarir are dominantly volcanic, subaerial, and locally derived, I think that they should be excluded from the Murdama group. Cole suggested (written commun., 1987) that they are analogous to the post-Murdama Jurdhawiyah group in the northern part of the Afif belt.

The Masama and Zain formations have been placed in the Murdama in some reports (Brock, 1983; Kellogg, 1982b, 1983). However, they are on strike with the Arfan and Juqjuq formations, which Hadley (1976) believed were pre-Murdama in age. Because they have little lithologic resemblance to typical Murdama rocks in the Mistahjed belt or elsewhere, they also should be excluded from the Murdama.

\section{Sources of Sediment and Depositional History}

Reconstruction of a depositional basin in the Mistahjed belt is made difficult by its structural complexity (fig. 12). Removing $120 \mathrm{~km}$ of left-lateral offset on the southern Najd fault zone would move the structural block that lies northeast of the Najd zone far enough southeastward to separate the two blocks as shown on plate 6 entirely. Thus, the Masama and Zain formations (fig. 16) did not lie opposite the Mistahjed belt during deposition of Murdama strata. Folding has decreased the width of the basin from what it was when sediments were deposited, although the amount is indeterminate. The effect of faulting on the basin may not have been very large; however, a strike-slip component on faults such as the one directly west of Jabals Bijad and Jarir has distorted the basin shape since Murdama time.

The overall distribution of facies in the Mistahjed belt favors a sediment source from the southwest. The best data come from the Jabal Yafikh quadrangle (Schmidt, 1981, p. 88-90). Schmidt believed that Murdama sediments once covered the entire Arabian shield east of Jabal Yafikh. The basal conglomerate of the Jarbuah is locally over $300 \mathrm{~m}$ thick and contains cobbles of the granodiorite and monzogranite of the Jabal Najeeb batholith, which lies between 10 and $30 \mathrm{~km}$ to the southwest. A local basal conglomerate of the Al Ghabiyah contains cobbles of potassic granite apparently derived from intrusions in the Wadi Miyah quadrangle, 
$50 \mathrm{~km}$ to the west. The basal conglomerates are overlain by a thick sequence of sandstone (Al Ghabiyah) that fines upward and northeastward to dominant siltstone in the Hoofer. Clasts in Yafikh formation conglomerate have not been identified with source rocks; however, exposures near the west side of the basin have a probable western source. Limestone accumulated during periods of slow to no clastic sedimentation.

\section{Origin of the Volcanic Rocks and the Jarir Formation}

Volcanic rocks are sparse in the Murdama group of the Mistahjed belt. Schmidt (1981) reported basalt interlayered with basal sedimentary rocks of the Jarbuah formation north of Wadi Mistahjed and abundant andesitic to rhyodacitic pyroclastic rocks at nearby Jabal Jarbuah. As those occurrences are limited in extent, they are probably of local origin. Rhyodacite to rhyolite welded tuffs a few tens of meters thick are also present in the upper part of the Al Ghabiyah formation in the Jabal Yafikh quadrangle (Schmidt, 1981). A rhyolite welded tuff layer is also present low within the Al Ghabiyah in the Wadi Mistahjed section. These tuffs appear to be confined to an area extending about $10 \mathrm{~km}$ to either side of Wadi Mistahjed, and may be near the distal ends of tuffs erupted from a source area to the west. I found metabasalt apparently more than $800 \mathrm{~m}$ thick in the Jabal Hashishiyah northeast section. This rock type was not reported by Hadley (1976), hence it must be a lenticular unit of local origin.

The Jarir formation apparently lies at the top of the layered section in the Mistahjed belt and is herein excluded from the Murdama group. As has been shown, it consists of metabasalt and andesite flows and breccias, basalt cobble conglomerate locally containing granite cobbles, sandstone containing chiefly mafic volcanic fragments, and dacitic ash-flow tuff and breccia near the top. Because of the absence of pillows or hyaloclastites, the area appears to have been subaerial when basaltic volcanism began. Sediments rich in mafic volcanic rock fragments were shed by the volcanoes and interlayered with flows and breccias. Granitic cobbles in some of the conglomerates may be reworked cobbles derived from the Jarbuah or Al Ghabiyah formations. During Jarir time, magma evolved to a more silicic composition culminating in the eruption of dacite tuff and breccia.

\section{JUNAYNAH BELT}

A belt of unmetamorphosed sedimentary rocks lies south of the village of Junaynah and northeast of Bishah (figs. 2, 14). The Junaynah belt lies $120 \mathrm{~km}$ west across the strike from the Mistahjed belt. It is a narrow ( 0.2 to $3 \mathrm{~km}$ ) north-south strip that is nevertheless $23 \mathrm{~km}$ long.

\section{Previous Work}

The Junaynah belt of sedimentary rocks is mostly on the 1:500,000-scale Southern Najd quadrangle (Jackson and others, 1963), but this map does not separate the belt from the adjacent layered rock units. Schmidt (1985, Junaynah 1:100,000-scale quadrangle) mapped these unmetamorphosed sedimentary rocks and correlated them with the Murdama group. The 1:250,000-scale compilation (Simons, 1984, Wadi Bishah quadrangle) shows the belt as mapped by Schmidt. The following descriptive material is a summary of Schmidt's work combined with my supplementary observations.

\section{Structure and Underlying Rocks}

The dominant geologic feature in the Junaynah area is a north-south-trending belt of layered rocks consisting of dacitic, andesitic, and basaltic flow rocks, tuffs, and related volcaniclastic rocks, assigned by Schmidt (1985) to the Halaban group. Directly to the west lies the narrow band of Murdama(?) sedimentary rocks, which lie principally within a north-south-trending fault zone. The fault zone is effectively a graben, but the sedimentary rocks overlap the bordering faults. Farther to the west lies a complex of intrusive rocks including tonalite, granodiorite, granite, and granitic gneiss, which at least in part unconformably underlie the Murdama(?) rocks. Schmidt (1985) assigned the intrusive rocks to pre-, syn-, and post-tectonic groupings.

\section{Murdama(?) Group}

The sedimentary rocks of the Junaynah belt consist of basal conglomerate, sandstone, and siltstone. They commonly dip eastward at $45^{\circ}$ or more, are highly sheared, and locally dip vertically adjacent to faults (fig. 14). Schmidt (1985) separately mapped a conglomerate unit about $300 \mathrm{~m}$ thick. The conglomerate commonly contains clasts from 1 to $10 \mathrm{~cm}$, and locally as large as 1 $\mathrm{m}$, of silicic plutonic rocks including tonalite and deeppink trondjemite. The sedimentary rocks lie unconformably on older plutonic rocks; good exposures of the unconformity are common. A few meters of very coarse to granule sandstone commonly lies between the plutonic rocks and the lowest conglomerate.

Conglomerate in some beds is composed of fragments of greenish- and brownish-gray silicic to mafic volcanic rocks, generally angular and 0.5 to $2 \mathrm{~cm}$ in size, locally larger and rounded. Conglomerate in other beds is composed of both volcanic and plutonic clasts, thus is polymictic.

Overlying the conglomerate unit is a sandstone and siltstone unit as much as $800 \mathrm{~m}$ thick which grades upward from thick, well-bedded coarse-grained to very 


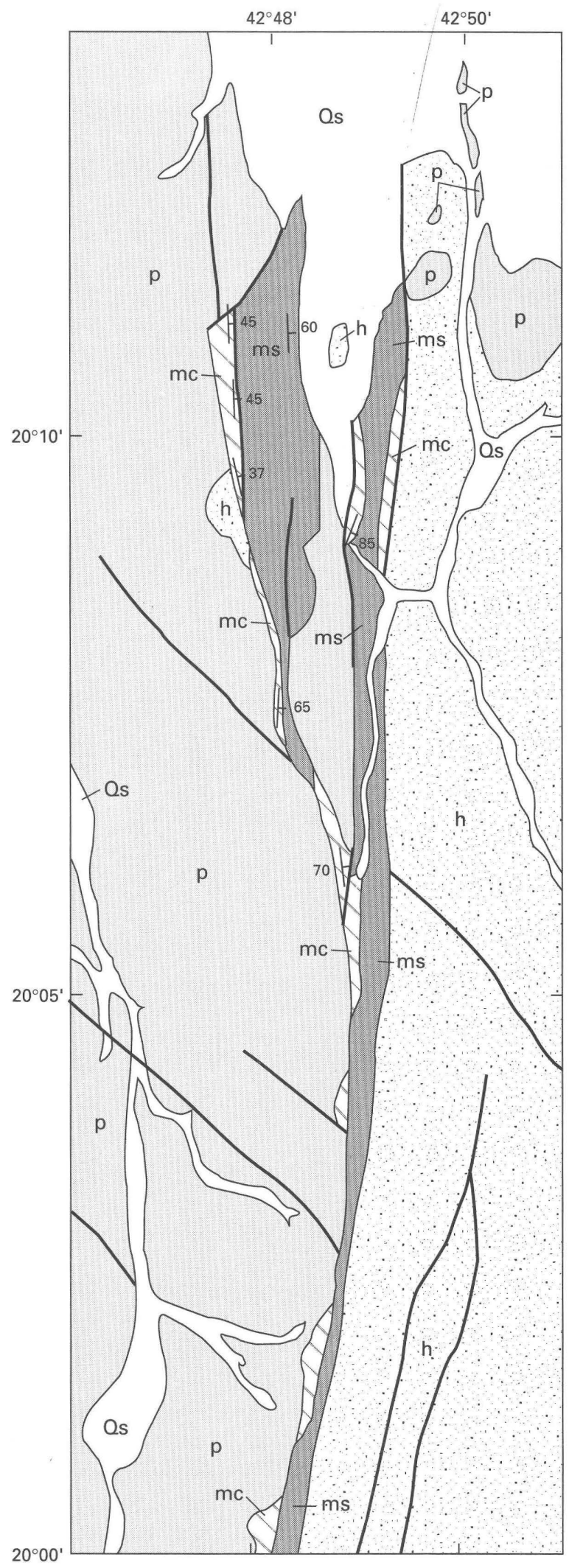

$\begin{array}{llll}0 & 1 & 2 & 3 \text { KILOMETERS }\end{array}$

\section{EXPLANATION}

Os Quaternary surficial deposits

Sandstone and siltstone

mi Polymictic conglomerate

h Older layered rocks

$\mathrm{p}$ Older plutonic rocks

Contact

Fault

$\stackrel{70}{+}$ Strike and dip of beds

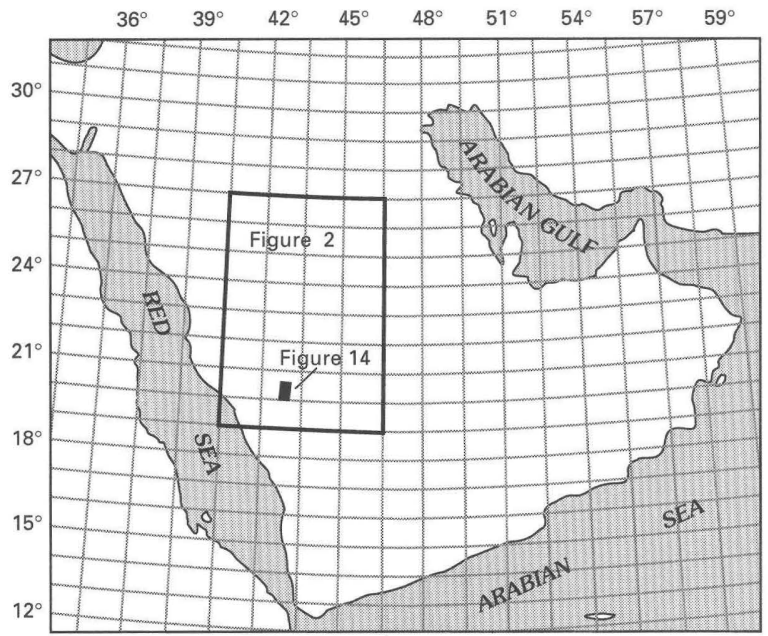

Figure 14. Geologic map of Junaynah belt. Geology simplified from 1:100,000-scale map of Junaynah quadrangle (Schmidt, 1985). Schmidt assigned map units $\mathrm{ms}$ and $\mathrm{mc}$ to the Murdama group. 
coarse grained sandstone to thin well-bedded finegrained sandstone and siltstone. Conglomerate is locally interbedded. The sandstones are mostly brownish-gray, poorly sorted, medium- to coarse-grained volcanic arenites containing grains of both silicic and andesitic rocks. Very coarse to granule sandstones are commonly arkosic arenites containing prominent pink feldspar grains. Siltstones are also brownish gray, commonly exhibit slaty cleavage, and have interbeds of sandstone. Many siltstones contain sparse floating sand grains. A single 1-m layer of greenish-gray altered basalt constitutes the only volcanic rock found in this area.

In the south part of the Junaynah belt, very fine to medium-grained sandstone and siltstone predominate, and conglomerate is less abundant. The sandstone and siltstone are mostly medium gray and greenish gray and are quartz arenite and quartz wacke, consisting predominantly of quartz grains with matrix of metamorphic chlorite, muscovite, and calcite.

\section{Depositional Basin}

The Murdama(?) sedimentary rocks of the Junaynah belt appear to have been deposited in a narrow fault trough or yoked basin. Sediments were locally derived from the plutonic rocks to the west and from the volcanic rocks to the east. The rapidly disintegrating plutonic rocks supplied debris including granule sand, cobbles, and boulders to the lower part of the section. The more slowly eroding volcanic rocks to the east contributed coarse- to fine-grained sand and silt that was masked by coarse debris at first, then formed the principal components of the rock higher in the section. Finegrained, more quartzose sandstone and siltstone preserved in the south part of the belt signal a change in source back to the plutonic terrane, now relatively low lying and shedding sediments slowly.

The character of the rocks and the narrowness of the basin suggest a short-lived history of rifting and basin fill.

\section{Correlation}

The clastic sedimentary rocks mapped as Murdama in the Junaynah area are similar to some of those from the Mistahjed and Afif belts. Volcanic rocks are sparse, however, and limestone is conspicuously absent.

I believe that these rocks should be excluded from the Murdama for the following reasons: (1) although some clastic lithologies are similar to those in the Afif and Mistahjed belts, a key lithology, limestone, is missing; (2) the age of these rocks is apparently younger than that of Murdama rocks in the other belts (see the section entitled "Geochronology"); (3) the tectonic environment appears to be that of a yoked basin on a continental plate, thus unrelated to a subduction zone marked by the Nabitah belt, as proposed for the belts of Murdama rocks (see the section entitled "Plate Tectonic Interpretation").

\section{LITHOLOGIC UNITY OF THE MURDAMA GROUP}

In my view, the lithologic unity of the Murdama group and Hibshi formation in the Afif, Jabal Hadhah, and Mistahjed belts is their most outstanding feature, and supports the age interpretation outlined in the following section.

In the Afif belt, monotonous sections of greenish volcanic arenites constitute the bulk of the As Sawadah, Jabal Zaydi, Wadi Sirrah, Jabal Raqabah, Jabal Murdama, Wadi Jarir, Jabal umm Sammah, and Jabal Khidar (Hibshi formation) sections. In the Jabal Hadhah and Mistahjed belts, the similarity is less striking, but many rocks at the Hashishiyah northwest, Wadi Mistahjed, and north of Jabal Jarir sections are also of the same character.

The principal rock type that unifies the Murdama, however, is the limestone. Limestone is present at a string of localities extending northwest along the east edge of the Afif belt from Jabal Farida to Jabal ash Shuban (pls. 1, 2). Limestone is also present at scattered localities in several basins between Nuqrah and Afif (fig. 2). It is also present at Jabal Hadhah and at several localities in the Mistahjed belt (fig. 12). As has been emphasized in preceding sections, limestone at many of these localities is strikingly distinctive, consisting in part of light-gray, tan-weathering rock and in part of darkgray, gray-weathering rock and locally containing stromatolites.

The section and area descriptions presented in this report suggest that the limestone is everywhere low in the stratigraphic sequence. A consideration of the radiometric ages and of plate tectonics (see following sections) suggests, however, that the oldest rocks, including the limestones, in the Jabal Hadhah and Mistahjed belts are younger than those in the Afif belt.

In the north part of the Afif belt, the position and lithology of the Hibshi formation also serves to unify the Murdama, if the Hibshi is considered to be basal to the generally finer grained Murdama rocks in the northernmost part of the Afif belt, as originally proposed by Williams (1983). If so, the strikingly similar sequences of volcanic arenites at Wadi Jarir, Jabal umm Sammah, and Jabal Khidar (Hibshi formation) are correlative, and the Hibshi conglomerate and volcanic rocks at Jabal Hibshi are basal to the Murdama section, just as are those of the Jarbuah formation in the Mistahjed belt. A coarser, basal facies is thus provided at the north end of the Afif belt, partially enclosing the basin consisting of the finer grained sedimentary rocks of the Maraghan formation. 


\section{GEOCHRONOLOGY}

As new radiometric ages from the central and northern shield have accumulated, the apparent age of the Murdama group and associated rocks has undergone changes and refinements. The basic framework is now provided by $\mathrm{U}-\mathrm{Pb}$ ages on zircon separates, particularly those reported by Stacey and others (1984) and by Cole and Hedge (1986). Several other U-Pb ages are also available, and $\mathrm{Rb}-\mathrm{Sr}$ and $\mathrm{K}-\mathrm{Ar}$ ages also merit consideration.

\section{Radiometric Ages from the Afif Belt and Adjacent Areas}

The ages reported by Stacey and others (1984) and Cole and Hedge (1986) are mostly from the central and northern parts of the Afif belt and are pertinent to the age of the Murdama and Jurdhawiyah groups and the Hibshi formation. Most of the ages are from plutonic rocks, including the pre-Murdama Suwaj suite, the postMurdama Idhah and Abanat suites, and the pre-Hibshi Laban complex. The age of a dacite in the Hibshi has also been determined. Revised decay constants have slightly changed the ages of Stacey and others (1984) since the preliminary data appeared in Greene (1983). The revised ages are listed (table 12), illustrated in a diagram (fig. 15), and discussed in the following paragraphs.

Age-dated rocks underlying the Murdama to the east of the Afif belt include the tonalite of the As Sawda domain of Delfour (1979) northwest of Halaban, with an age of $677 \pm 9 \mathrm{Ma}$ (No. 14, fig. 15). This rock directly underlies limestone (Farida marble) of the Jabal Damkh section, and cobbles of the tonalite appear in basal conglomerate of the Murdama in the nearby Jabal Qatar section. Thus, this age gives a firm maximum for the Murdama, at least in this area. Nearby gabbro of the Urd group ("ophiolitic complex") has an age of $695 \pm 9 \mathrm{Ma}$, providing confirmation for the existence of rocks older than $675 \mathrm{Ma}$ in this area.

Diorite, tonalite, and quartz diorite of the Suwaj suite plutonic complex lying east of Al Jurdhawiyah have similar ages of $683 \pm 5,684 \pm 5$, and $689 \pm 5 \mathrm{Ma}$ (Nos. 11, 10, 9; fig. 15). These rocks underlie conglomerate of the Jurdhawiyah group along an extensive contact and underlie sandstone, conglomerate, and limestone of the Murdama in small areas near Jabal Kitayfah and Uglat as Suqur.

From west of the Afif belt near Jabal Murdama, an $\mathrm{Rb}$-Sr age of $718 \pm 25 \mathrm{Ma}$ (No. 12, fig. 15) was reported by Fleck and Hadley (1982) on granodiorite that intrudes volcanic rocks (An Nayzah formation of Letalenet, 1979) stratigraphically below Murdama rocks. Stoeser and Stacey (1988) reported two U-Pb ages on plutonic rocks in this area. One, $647 \pm 7 \mathrm{Ma}$ (No. 12A, fig. 15), is from virtually the same locality as the $718 \pm 25-\mathrm{Ma} \mathrm{Rb}-\mathrm{Sr}$ age and is probably more reliable. Another of $673 \pm 9 \mathrm{Ma}$ (No. 12B, fig. 15) is on tonalite from a locality about 25 $\mathrm{km}$ to the west. These deformed plutonic rocks are believed to be contemporaneous with deformation that preceded deposition and eruption of the Afif formation, which underlies the Murdama (Letalenet, 1979). These ages, if correct, form a significant constraint on the age of the Murdama near Afif, confining it to less than 650 Ma (fig. 15).

Darbyshire and others (1983) reported an age of $616 \pm 13 \mathrm{Ma}$ (No. 15, fig. 15) for volcanic rocks near Bir Jahad, in the Wadi ar Rika quadrangle (Delfour, 1980), $80 \mathrm{~km}$ northwest of the As Sawada measured section (this report). The rocks are mapped as the Hulayfah group (Nuqrah formation), and are separated from the overlying Murdama group of the southernmost part of the Afif belt by a nonangular unconformity. The 10point isochron displays excellent linearity over a wide range of $87 \mathrm{Rb} / 86 \mathrm{Sr}$ values. However, this age is in conflict with the more reliable $\mathrm{U}-\mathrm{Pb}$ ages on rocks intrusive into the Murdama, cited below, thus it does not appear to constitute important evidence for an age of less than 616 Ma for the Murdama.

Radiometric ages on rocks intrusive into the Murdama, Hibshi, and Jurdhawiyah establish minimum ages for these units. Plutonic rocks of the Idhah suite intrude the Murdama and locally other units. Granodiorite and quartz diorite plutons south of Al Jurdhawiyah have U-Pb zircon ages of $620 \pm 7$ and $621 \pm 7 \mathrm{Ma}$ (Nos. 7, 8; fig. 15) (Cole and Hedge, 1986) and intrude both the Murdama and Jurdhawiyah groups. Granodiorite northeast of Uglat as Suqur is part of a group of small plutons intruding the Murdama rocks of the Bakrah arch and Maraghan basin and has an age of $614 \pm 5 \mathrm{Ma}$ (No. 4, fig. 15) (Cole and Hedge, 1986). Finally, the same authors determined an age of $621 \pm 8 \mathrm{Ma}$ (No. 3, fig. 15) on the granodiorite that intrudes the Hibshi formation near An Nimriyah.

Rocks of the Abanat suite are younger still, most younger than $600 \mathrm{Ma}$. Plutons that intrude the Murdama include the granodiorite of Jabal Qutn, directly north of Uglat as Suqur, with an Rb-Sr age of $579 \pm 4 \mathrm{Ma}$ (No. 5, fig. 12) (Stuckless and others, 1984), and the granite of Jabal as Silsilah, with a U-Pb age of $587 \pm 8 \mathrm{Ma}$ (No. 6, fig. 15) (du Bray, 1984).

Two $\mathrm{U}-\mathrm{Pb}$ ages indicative of the age range of the Hibshi formation were determined by Cole and Hedge (1986). A dacite from within the Hibshi east of Samirah was successfully dated at $632 \pm 5 \mathrm{Ma}$ (No. 2, fig. 15), and tonalite from the Laban complex nearby that is unconformably overlain by the Hibshi yielded an age of $650 \pm 7 \mathrm{Ma}$ (No. 1, fig. 15). 
Table 12. Radiometric ages from the Afif, Mistahjed, and Junaynah belts and adjacent areas

\begin{tabular}{|c|c|c|c|c|c|c|}
\hline Location & Rock type & Unit & $\begin{array}{l}\text { Age } \\
\text { (Ma) }\end{array}$ & Method & Reference* & $\begin{array}{l}\text { Number } \\
\text { on fig. } 15\end{array}$ \\
\hline \multicolumn{7}{|c|}{ Afif belt, underlying rocks } \\
\hline As Sawada & tonalite & Suwaj suite & $677 \pm 9$ & $\mathrm{U}-\mathrm{Pb}$ & 1 & 14 \\
\hline Halaban & gabbro & Suwaj suite (Urd) & $695 \pm 9$ & $\mathrm{U}-\mathrm{Pb}$ & 1 & 13 \\
\hline Jabal Suwaj & diorite & Suwaj suite & $683 \pm 5$ & $\mathrm{U}-\mathrm{Pb}$ & 2 & 11 \\
\hline Muzayfir & tonalite & Suwaj suite & $684 \pm 5$ & $\mathrm{U}-\mathrm{Pb}$ & 2 & 10 \\
\hline Samra Khaytan & quartz diorite & Suwaj suite & $689 \pm 5$ & $\mathrm{U}-\mathrm{Pb}$ & 2 & 9 \\
\hline Afif south & granodiorite & Afif-Án Nuqrah & $718 \pm 25$ & $\mathrm{Rb}-\mathrm{Sr}$ & 3 & 12 \\
\hline Afif south & tonalite & Afif fm.(composite) & $647 \pm 7$ & $\mathrm{U}-\mathrm{Pb}$ & 10 & $12 \mathrm{~A}$ \\
\hline Afif southwest & granodiorite & Afif fm.(composite) & $673 \pm 9$ & $\mathrm{U}-\mathrm{Pb}$ & 10 & $12 \mathrm{~B}$ \\
\hline Bir Jahad & volcanic suite & Nuqrah formation & $616 \pm 13$ & $\mathrm{Rb}-\mathrm{Sr}$ & 6 & 15 \\
\hline \multicolumn{7}{|c|}{ Afif belt, intrusive into Murdama or Hibshi } \\
\hline Jabal al Asfar & granodiorite & Idhah suite & $620 \pm 7$ & $\mathrm{U}-\mathrm{Pb}$ & 2 & 7 \\
\hline Badi Mushrifah & quartz diorite & Idhah suite & $621 \pm 7$ & $\mathrm{U}-\mathrm{Pb}$ & 2 & 8 \\
\hline Darat al Jibu & granodiorite & Idhah suite & $614 \pm 5$ & $\mathrm{U}-\mathrm{Pb}$ & 2 & 4 \\
\hline An Nimriyah & granodiorite & Idhah suite & $621 \pm 8$ & $\mathrm{U}-\mathrm{Pb}$ & 2 & 3 \\
\hline Jabal Qutn & granite & Abanat suite & $579 \pm 4$ & $\mathrm{Rb}-\mathrm{Sr}$ & 4 & 5 \\
\hline Jabal Silsilah & granite & Abanat suite & $587 \pm 8$ & $\mathrm{U}-\mathrm{Pb}$ & 5 & 6 \\
\hline Jabal Tin & granodiorite & Laban complex & $658 \pm$ & $\mathrm{K}-\mathrm{Ar}$ & 11 & $3 \mathrm{~A}$ \\
\hline \multicolumn{7}{|c|}{ Afif belt, Hibshi formation and underlying rocks } \\
\hline Jabal as Salah & dacite & Hibshi formation & $632 \pm 5$ & $\mathrm{U}-\mathrm{Pb}$ & 2 & 2 \\
\hline Samirah east & tonalite & Laban complex & $650 \pm 7$ & $\mathrm{U}-\mathrm{Pb}$ & 2 & 1 \\
\hline \multicolumn{7}{|c|}{ Mistahjed belt, Bir Juqjuq quadrangle, underlying rocks } \\
\hline Jabal Arfan & volcanic suite & Arfan formation & $608 \pm 9$ & $\mathrm{Rb}-\mathrm{Sr}$ & 6 & 16 \\
\hline south of Jabal Tarban & volcanic suite & Juqjuq formation & $612 \pm 22$ & $\mathrm{Rb}-\mathrm{Sr}$ & 6 & 17 \\
\hline east of Jabal Ayyanah & rhyolite tuff & Arfan formation & $761 \pm 23$ & $\mathrm{Rb}-\mathrm{Sr}$ & 7 & 20 \\
\hline Jabal Arfan & basaltic andesite & Arfan formation & 775 & $\mathrm{Rb}-\mathrm{Sr}$ & 7 & 21 \\
\hline northeast of Bir Juqjuq & andesite & Juqjuq formation & $620 \pm 95$ & $\mathrm{Rb}-\mathrm{Sr}$ & 7 & 18 \\
\hline south of Jabal Tarban & rhyolite tuff & Juqjuq formation & 612 & $\mathrm{Rb}-\mathrm{Sr}$ & 7 & 19 \\
\hline \multicolumn{7}{|c|}{ Mistahjed belt, Yafikh quad.rangle, underlying rocks } \\
\hline Wadi Jarbuah & rhyolite tuff & Al Ghabiyah fm & $568 \pm 29$ & $\mathrm{Rb}-\mathrm{Sr}$ & 7 & 22 \\
\hline Wadi Jereibie & diorite & "young" & $584 \pm 7$ & $\mathrm{~K}-\mathrm{Ar}$ & 8 & 23 \\
\hline Wadi Jereibie & diorite & "young" & $620 \pm 7$ & $\mathrm{~K}-\mathrm{Ar}$ & 8 & 24 \\
\hline Wadi Mistahjed & diorite & "young" & $627 \pm 9$ & $\mathrm{~K}-\mathrm{Ar}$ & 8 & 25 \\
\hline Wadi Mistahjed & diorite & "young" & $632 \pm 20$ & $\mathrm{Ar}-\mathrm{Ar}$ & 8 & 26 \\
\hline Wadi Mistahjed & diorite & "young" & $651 \pm 12$ & $\mathrm{~K}-\mathrm{Ar}$ & 8 & 27 \\
\hline Wadi Mistahjed & granodiorite & Jabal Najeeb & $610 \pm 8$ & $\mathrm{~K}-\mathrm{Ar}$ & 8 & 28 \\
\hline Wadi Mistahjed & granodiorite & Jabal Najeeb & $623 \pm 5$ & $\mathrm{Ar}-\mathrm{Ar}$ & 8 & 30 \\
\hline Wadi Mistahjed & tonalite & uncertain & $666 \pm 8$ & $\mathrm{U}-\mathrm{Pb}$ & 9 & 31 \\
\hline \multicolumn{7}{|c|}{ Junaynah belt, underlying rocks } \\
\hline Jabal Najiah & granite & Jabal Najiah & $606 \pm 8$ & $\mathrm{~K}-\mathrm{Ar}$ & 8 & 32 \\
\hline Jabal Najiah & granite & Jabal Najiah & $612 \pm 8$ & $\mathrm{~K}-\mathrm{Ar}$ & 8 & 33 \\
\hline Jabal Yellah & granite & Bishah red & $603 \pm 8$ & $\mathrm{~K}-\mathrm{Ar}$ & 8 & 34 \\
\hline Jabal Yellah & granite & Bishah red & $606 \pm 8$ & $\mathrm{~K}-\mathrm{Ar}$ & 8 & 35 \\
\hline Jabal Yellah & granite & Bishah red & $678 \pm 10$ & U-PB & 9 & 36 \\
\hline \multirow[t]{6}{*}{ *References for table 12 : } & \multicolumn{2}{|c|}{ 1. Stacey and others (1984). } & \multicolumn{2}{|c|}{ 6. Darbyshire and others (1983). } & & \\
\hline & \multicolumn{2}{|c|}{ 2. Cole and Hedge (1986). } & \multicolumn{2}{|c|}{ 7. Fleck and others (1980). } & & \\
\hline & \multicolumn{2}{|c|}{ 3. Fleck and Hadley (1982). } & \multicolumn{2}{|c|}{ 8. Fleck and others (1976). } & & \\
\hline & \multicolumn{2}{|c|}{ 4. Stuckless and others (1984). } & \multicolumn{2}{|c|}{ 9. Cooper and others, 1979). } & & \\
\hline & \multicolumn{2}{|l|}{ 5. du Bray (1984). } & \multicolumn{2}{|c|}{ 10. Stoeser and Stacey (1988). } & & \\
\hline & 5. All ages quoted in & d Hedge (1986). & 1. Aldrich and & 978). & & \\
\hline
\end{tabular}




\section{Discussion}

These ages give an age range for the Murdama group, Hibshi formation, and Jurdhawiyah group of 647 to $621 \mathrm{Ma}$, citing the most restrictive ages for underlying and intruding rocks irrespective of the analytical error bars. Thus the deposition of Murdama, Hibshi, and Jurdhawiyah strata spans a time of 25-30 m.y., accord- ing to the $\mathrm{U}-\mathrm{Pb}$ evidence. However, as suggested by the speculative age range (fig. 15), neither the time required for the accumulation of the Jurdhawiyah group nor the ages of the oldest rocks of the intruding Idhah suite necessarily restrict the minimum age of the thickest Murdama sections, which are in the south part of the Afif belt.

Stacey and others (1984) were also prone to discount the Bir Jahad age ( $616 \pm 13 \mathrm{Ma})$, stating that "such

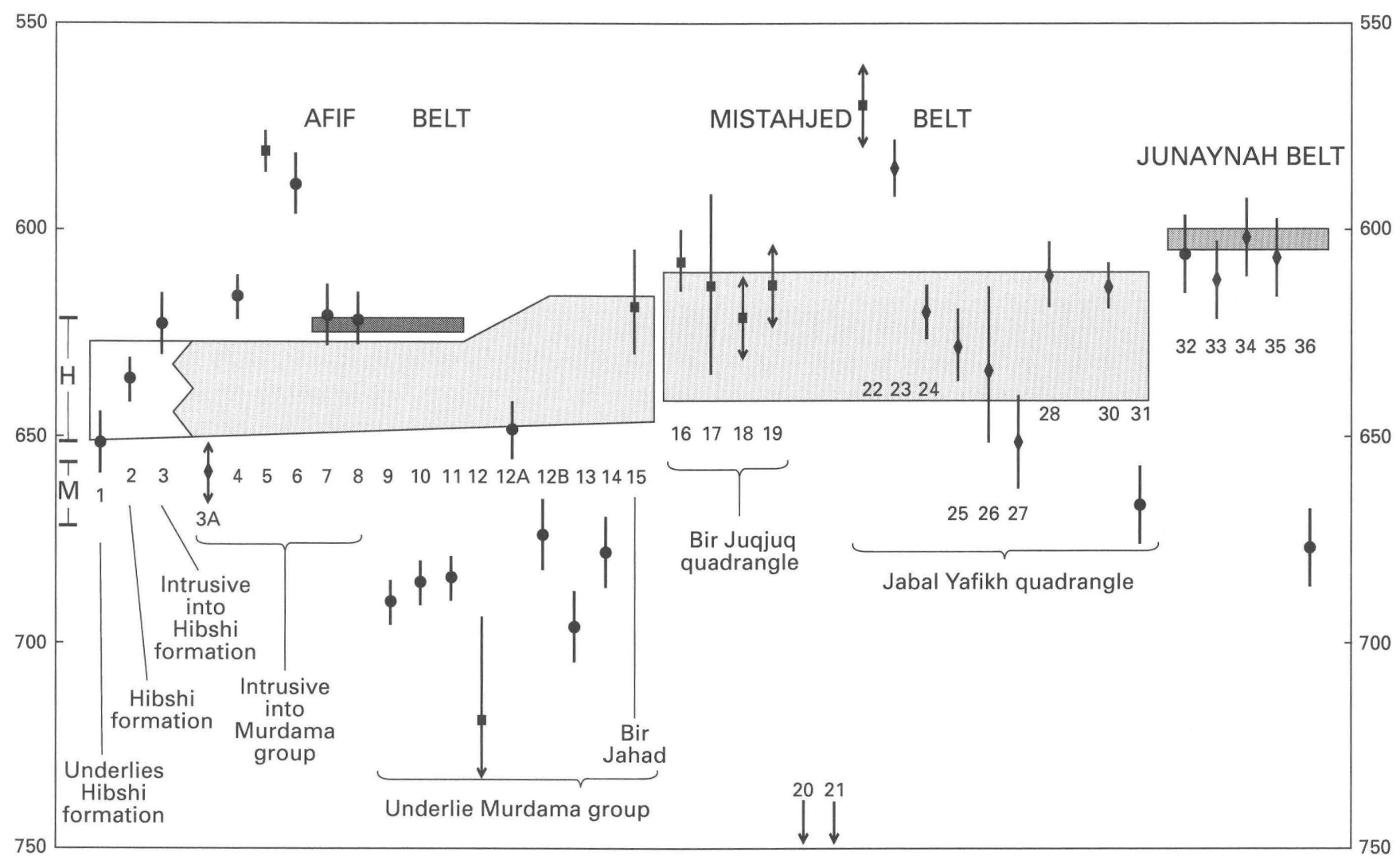

\section{EXPLANATION}

$\uparrow$ Age range-From radiometric determination. Arrow indicates no range given or limit off graph

- U-Pb

- $\mathrm{Rb}-\mathrm{Sr}$

- K-Ar

$9 \quad$ Number refers to table 12
Speculative age range

\section{Hibshi formation}

Murdama group

Jurdhawiyah group

Junaynah belt rocks

Age range-According to Cole and Hedge (1986)

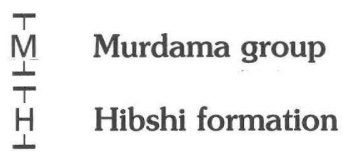

Figure 15. Radiometric ages with error bars and speculative age ranges of units. Arrangement is generally from northwest to southeast except for Junaynah belt, which lies west of Mistahjed belt. Ages are in millions of years before present (Ma). 
ages on volcanic rocks are often too young." J.C. Cole (oral commun., 1988) was also doubtful about the Bir Jahad age but conceded that the ages of Stacey and Stoeser (1988) on underlying rocks $(647 \pm 7$ and $673 \pm 9$ Ma) near Afif apparently restrict the basal part of the Murdama to less than $650 \mathrm{Ma}$ there.

Cole and Hedge (1986) argued, however, that the Murdama is older than $655 \mathrm{Ma}$ and underlies the Hibshi formation near the north end of the Afif belt. They proposed that a pluton near Jabal Tin that intrudes the Murdama is in fact part of the same intrusive unit (Laban complex) that underlies the Hibshi formation east of Samirah and is dated at $650 \pm 7 \mathrm{Ma}$. They cited the following reasons for the correlation: (1) bulk composition, compositional diversity, and presence of abundant mafic dikes are similar to the Laban; (2) its magnetic signature is similar to the Laban; (3) it does not intrude the Hibshi; and (4) a biotite K-Ar age of $658 \mathrm{Ma}$ (No. 3A, fig. 15) was reported from the pluton (Aldrich and others, 1978, recalculated to decay constants of Steiger and Jager, 1977). Cole and Hedge stated that the age of onset of deposition of the Murdama is uncertain, but proposed $670 \mathrm{Ma}$ as a likely time. Thus, they believed that the Murdama is substantially older than the Hibshi formation and Jurdhawiyah group.

\section{Radiometric Ages from the Mistahjed Belt and Adjacent Areas}

The ages of the Arfan and Juqjuq formations in the Bir Juqjuq quadrangle (Hadley, 1976) may be pertinent to the age of the Murdama group, but the relationships among the three units are unclear. Hadley believed that the Arfan and Juqjuq formations are older than the Murdama, and authors of adjacent quadrangle maps have followed suit (Schmidt, 1981; Greene, in press c). However, contacts separating the units are all faults. Stratigraphic order is clearly established only for part of the Arfan.

Radiometric ages on volcanic rocks from the Arfan and Juqjuq formations have been published by Fleck and others $(1976,1980)$ and Darbyshire and others (1983) (table 12, fig. 15). Rb-Sr ages reported by Fleck and others (1980) are $761 \pm 23$ and $775 \mathrm{Ma}$ (Nos. 20, 21; fig. 15) for the Arfan formation and 620 95 and $612 \mathrm{Ma}$ (Nos. 18, 19; fig. 15) for the Juqjuq formation. These ages have been considered doubtful, especially those on the Arfan formation, which are older than any U-Pb ages from the west part of the Arabian shield. Ages that have been more widely accepted are those by Darbyshire and others (1983), which are 608 \pm 9 and 612 $\pm 22 \mathrm{Ma}$ (Nos. 16, 17; fig. 15), on samples from the Arfan and Juqjuq formations, respectively. They are based on excellent $\mathrm{Rb}-\mathrm{Sr}$ isochrons; the authors believed that they show the two formations to be correlative. However, these ages, like the Bir Jahad age, may be too young.

The Arfan formation has been substantially extended on the 1:250,000-scale Jabal Khida (Thieme, 1985, 1988), Rawdah (Al Muallem and Smith, 1984) and Zalm (Agar, 1984) quadrangles. Rocks previously assigned to the Murdama group or Farida marble (Jackson and others, 1963; Hadley, 1976; Greene, in press c; this report) have been reassigned, mostly to the Arfan formation. These compilations have unfortunately tended to confuse rather than resolve the Arfan-Murdama relationship.

In the Jabal Yafikh quadrangle (Schmidt, 1981), a welded tuff from the rhyolite member of the Al Ghabiyah formation of the Murdama group yielded an age of $568 \pm 29 \mathrm{Ma}$ (No. 22, fig. 15) from an $\mathrm{Rb}-\mathrm{Sr}$ whole-rock three-point isochron (Fleck and others, 1980). Fleck and others believed that this age may be disturbed, but Schmidt (1981) believed that the maximum age of $600 \mathrm{Ma}$ indicated by the analytical error range may be acceptable. This age is still too young to correlate with the Murdama in the Afif belt, and I agree with Fleck that it is most likely disturbed.

Diorite and quartz diorite from five localities underlying the base of the Jarbuah formation (lowermost part of the Murdama) in the Jabal Yafikh quadrangle give ages ranging from 651 to $584 \mathrm{Ma}$ (table 12, Nos. 23-27) by $\mathrm{K}-\mathrm{Ar}$ and Ar-Ar methods (Fleck and others, 1976; ages revised using new decay constants, written commun. 1977). Fleck and others (1976) considered these ages to be disturbed and the minimum age to be $650 \mathrm{Ma}$, but Schmidt (1981) believed that $650 \mathrm{Ma}$ is the maximum age for these rocks, as four of the ages fall between 620 and $650 \mathrm{Ma}$ (table 12). I am inclined to agree with Schmidt. The granodiorite of Jabal Nejeeb lies directly beneath basal conglomerate of the Jarbuah formation and yielded a disturbed $\mathrm{K}-\mathrm{Ar}$ age of $610 \pm 8$ Ma (No. 28, fig. 15) and a disturbed Ar-Ar age of $623 \pm 5$ Ma (No. 30, fig. 15) (Fleck and others, 1976). Schmidt believed that this rock may be $25 \mathrm{~m}$.y. older than the 625-Ma Wadi Musayrah batholith of the adjacent Jabal al Qarah quadrangle and, therefore, $650 \mathrm{Ma}$.

A final age of interest from the Jabal Yafikh quadrangle is one of $666 \pm 8 \mathrm{Ma}$ (No. 31, fig. 15) by the U-Pb method, on tonalite collected a short distance from the unconformably overlying Jarbuah formation (Cooper and others, 1979).

The bulk of the foregoing evidence suggests, but does not definitely indicate, that the age of the Murdama rocks in the Mistahjed belt is less than $650 \mathrm{Ma}$. The hardest data are provided by the one $\mathrm{U}-\mathrm{Pb}$ age, which indicates only that the rocks are younger than $666 \mathrm{Ma}$. A speculative age range of 640 to $610 \mathrm{Ma}$ is indicated (fig. 15) for the rocks of this belt. 


\section{Radiometric Ages from the Junaynah Area}

For the Junaynah area, K-Ar ages of $606 \pm 8$ and $612 \pm 8 \mathrm{Ma}$ (Nos. 32, 33; fig. 15) on biotite seperates from the syenogranite of Jabal Najiah are considered to be reliable ages (Schmidt, 1985; Fleck and others, 1976; revised to new decay constants). This is a post-tectonic granite believed to be of similar age to that underlying the sedimentary rocks mapped as the Murdama. Alkali feldspar granite ("Bishah red granite") directly underlying these rocks gives questionable $\mathrm{K}-\mathrm{Ar}$ ages of $603 \pm 8$ and $606 \pm 8 \mathrm{Ma}$ (Nos. 34, 35; fig. 15) (Fleck and others, 1976, revised). Finally, Cooper and others (1979) reported a U-Pb age of $678 \pm 10 \mathrm{Ma}$ (No. 36, fig. 15) on "Bishah red granite" from the same area. In view of the consistent $\mathrm{K}$-Ar ages, this age was for many years believed to be too old.

However, $\mathrm{U}-\mathrm{Pb}$ ages are now considered the most reliable, and this one tells us that the layered rocks mapped as the Murdama may be of any age less than $678 \mathrm{Ma}$. The $\mathrm{K}-\mathrm{Ar}$ ages suggest that they are younger than $605 \mathrm{Ma}$, and their speculative age range is so indicated (fig. 15). If this is their true age, they do not belong in the Murdama group.

\section{Interpretation}

As I see it, the weight of evidence favors an age range for the Hibshi, Murdama, and Jurdhawiyah in the Afif belt of 650 to $615 \mathrm{Ma}$ (fig. 15). This interpretation rejects the suggestion of Cole and Hedge (1986) that the Murdama is intruded by a $650-\mathrm{Ma}$ granite. The ages of the Jabal Hadhah belt and other minor belts northwest and southwest of Afif (fig. 2) are poorly constrained, but the $\mathrm{Rb}-\mathrm{Sr}$ and $\mathrm{K}$-Ar ages from the Mistahjed belt suggest that the age of the rocks is less than $650 \mathrm{Ma}$. The platetectonic interpretation that follows suggests that deposition in the Jabal Hadhah and Mistahjed belts did not commence until that in the Afif belt was well underway. The radiometric ages are not inconsistent with this idea.

This interpretation has the following advantages: (1) The unity of the group is preserved, and the correlation of the Hibshi formation with similar rocks mapped as the Murdama is established. (2) It is consistent with radiometric ages from the Mistahjed belt. Although uncertainties are large in most of these ages, they all point toward a maximum age of $650 \mathrm{Ma}$ or less for Murdama rocks. (3) The ages of Darbyshire and others (1983) on the Arfan and Juqjuq formations (608 \pm 9 and $612 \pm 22$ $\mathrm{Ma}$, respectively), although a little young, may be accepted as indicative of the ages of volcanic rocks being erupted between the Jabal Burkah belt and the Nabitah belt (see plate-tectonic interpretation below) contemporaneous with Murdama deposition, though they do not appear to be the principal source of sediments.
The principal disadvantage of this interpretation is that the deposition of the Hibshi, Murdama, and Jurdhawiyah strata is confined to a relatively short period, about 30 m.y. near Uglat as Suqur where both Murdama and Jurdhawiyah rocks are present. However, the Murdama strata may have been folded contemporaneous with late stages of deposition, and the Jurdhawiyah deposited after a short erosion interval (fig. 15). In the south part of the Afif belt where the thickest sections of the Murdama are located, more time may have been available if continued Murdama deposition contemporaneous with the Jurdhawiyah to the north is accepted. An interval of 35 m.y. for the Murdama alone is suggested (fig. 15), which provides sufficient time for sediment accumulation.

\section{PLATE-TECTONIC INTERPRETATION}

Considerable attention has been given in recent years to the problem of extending plate-tectonic interpretations based on Phanerozoic rock sequences back to Proterozoic rocks, such as those of the Arabian shield. The rocks of the shield are of latest Proterozoic age; the most recent work (Cole and Hedge, 1986) shows that ages range to as late as the beginning of Cambrian time (approximately $570 \mathrm{Ma}$, Palmer, 1983). Therefore, the shield rocks record an important connecting link between Proterozoic and Phanerozoic time.

Hypotheses proposed to explain the development of the Arabian shield have been diverse and have included accretion of magmatic arcs, accretion of microplates, and filling of intracratonic rifts. Some of the earliest proposals called for the accretion of magmatic arcs above an east-dipping subduction zone (Greenwood and others, 1976; Frisch and Al-Shanti, 1977; Fleck and others, 1980). Other proposals specified magmatic arc accretion above successive west-dipping subduction zones (Schmidt and others, 1979; Hadley and Schmidt, 1979; Greenwood and others, 1982). A hypothesis calling for the accretion of microplates was developed in slightly different forms by Stacey and others (1984), Stoeser and others (1984), and Stoeser and Camp (1985). Finally, proposals involving the filling of intracratonic rifts in an older continental plate were advanced by Engel and others (1980), Delfour (1981b), and Kemp and others (1982a).

The following speculative scenario describes a possible plate-tectonic setting for the basin in which the Murdama sediments were deposited. It makes the assumption that the voluminous volcanic rocks required as a source for the Murdama sediments were most likely erupted near a plate margin, probably a convergent one.

A stable, perhaps continental, platform (Afif terrane of Stoeser and Camp, 1985) may have been present at the beginning of Murdama time, and provided the 
basement on which the Murdama materials were deposited. This platform was bounded on the west by a volcanic arc and, farther west, an east-dipping subduction zone (Wallace and Rowley, 1986). The trace of the subduction zone is now found in the belt of serpentinite, gabbro, and ultramafic rock bodies generally known as the Nabitah belt (figs. 2, 16). I will point out the existence of an additional belt of mafic-ultramafic rocks that is closely related to the Nabitah belt.

The importance of the Nabitah belt, and of a possible connection between ultramafic rocks west of Nuqrah (pl. 1) and those of the Nabitah fault zone proper, was first recognized by Schmidt and others (1979) before much of the intervening region had been mapped. They considered the Nabitah belt to be a suture between crustal blocks, an idea expanded by subsequent workers, such as Stoeser and Camp (1985).

The position of the Nabitah belt in the southern part of the Arabian shield is represented by the Nabitah fault zone (Gonzalez, 1974; Worl, 1980; Greene, in press; Overstreet, 1978; Schmidt and others, 1979), which is a complex north-south structure consisting of several near-vertical fault traces and accompanying lenticular bodies of serpentinite. It extends south as far as lat $19^{\circ}$ near Hamdah (pl. 1).

Just north of lat $21^{\circ}$, the Nabitah fault zone is displaced by the southernmost Najd fault. North of here the Nabitah belt is traced principally by discontinuous occurrences of deformed serpentinite, gabbro, and ultramafic rocks which are generally deformed and continue in a band at least as far north as lat $26^{\circ}$ west of Nuqrah. Continuity of the belt was established by mapping and compilation of the 1:250,000-scale quadrangle maps: Rawdah (Al Muallem and Smith, 1984); Zalm (Agar, 1984); Afif (Letalenet, 1979), Mahd ad Dhahab (Kemp and others, 1982b); Al Hissu (Delfour, 1981a), and Nuqrah (Delfour, 1977). In the Nuqrah and Al Hissu quadrangles, bodies indicated may include basalt as it was also included in the "ophiolite" unit of Delfour (1977, 1981a).

Mafic-ultramafic rock bodies in the Nabitah belt north of lat $21^{\circ}$ are separated by faults, covered areas, and younger intrusive rocks. Many faults in this area are northwest-southwest-trending, left-lateral, Najd faults. It is tempting to reconstruct the Nabitah belt as a straight north-south feature continuous with the Nabitah fault zone of the southern shield; however, the true picture is unlikely to be so simple, especially in view of the presence of multiple belts of "ophiolite" near Al Hissu (figs. $2,16)$.

A belt of small bodies of gabbro and ultramafic rocks (Rharaba complex) crosses the Wadi ar Rika quadrangle (Delfour, 1980) southwest of the southern part of the Afif belt of Murdama rocks (fig. 2). A belt of small gabbro plutons (possibly accompanied by ultramafic rocks) continues to the southeast into the adjacent Jabal Khida 1:250,000-scale quadrangle (Thieme, 1985; Yeslam, 1974) nearly to the edge of the exposed part of the Arabian shield. To the northwest of the Wadi ar Rika quadrangle, sparse outcrops of gabbro and serpentinite continue, forming a belt crossing the Afif quadrangle directly southwest of the Afif belt of Murdama rocks, and gabbro continues into the adjacent Miskah quadrangle. Together these occurrences form a significant belt of mafic and ultramafic rocks. It may mark the location of a subduction zone that was the precursor of the Nabitah belt south of lat $24^{\circ} 30^{\prime}$, possibly joining the Nabitah belt near Al Hissu. I shall name it the Jabal Burqah belt, after a locality near the center of the Wadi ar Rika quadrangle.

No new evidence regarding the Nabitah belt and Arabian shield rocks lying to the west of it is presented in this report. However, the concepts that the Nabitah belt is a major suture zone between crustal blocks, and that the terrane lying to the west of it is composed of at least three accreted island arcs underlain by west-dipping subduction zones (Schmidt and others, 1979; Hadley and Schmidt, 1979; Greene, in press c), are consistent with the above described view of the Nabitah belt.

The locus of belts of volcanic source rocks on the west side of the Afif belt (pls. 1,2) plus limited data on sediment transport direction reported by Wallace and Rowley (1986) suggest that the principal source of Murdama sediments in the Afif belt is one or more active volcanic arcs lying immediately to the west. Wallace and Rowley further pointed out that the age data plus the presence of volcanic rocks interbedded with sedimentary rocks in the lower part of the Murdama suggest that volcanic rocks underlying the Murdama are only slightly older, and some may be of the same age.

These data suggest that the Murdama group of the Afif belt originated in a back-arc basin lying east of a volcanic arc of Andean type with accompanying subduction zone. The crust on which the volcanic arc and Murdama sedimentary rocks lie consists principally of voluminous intermediate to felsic plutonic rocks. These rocks were believed by Delfour $(1979,1980)$ to be Middle Proterozoic or older in age, but north of lat $23^{\circ}$ they have recently been shown to be mostly 690 to 650 Ma (Cole and Hedge, 1986), and they might well be of similar age further south. However, isotopic data (Stacey and Stoeser, 1983; Stoeser and others, 1984) suggest a component of older continental crust in this block.

This crust must have thinned considerably during the deposition of the Murdama sediments, as it was downwarped as much as $17.5 \mathrm{~km}$ (Wadi Sirrah section). Back-arc spreading is probably in part responsible.

Phanerozoic examples of apparent relict back-arc basins containing thick sedimentary fill are provided by Hsu (1988). The Tarim Basin in northwest China 


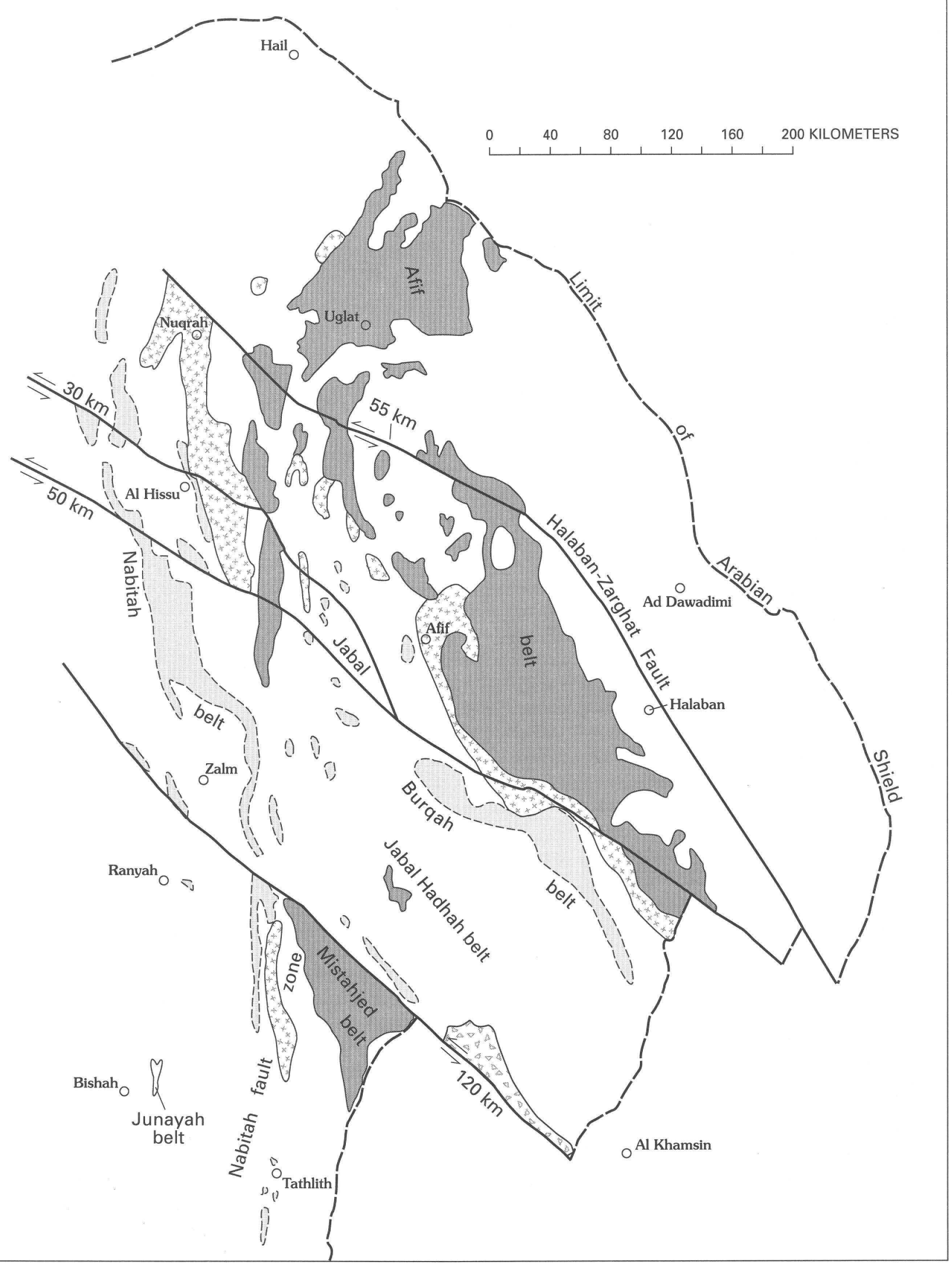

Figure 16. Palinspastic map of part of Arabian Shield showing $255 \mathrm{~km}$ of displacement on three major Najd faults removed. Outcrop patterns of the Murdama group and of scattered exposures of gabbro and ultramafic rocks simplified from figure 2. Masama and Zain formations and scattered exposures of volcanic rocks added from sources cited for figure 2. 
contains a maximum thickness of over $15 \mathrm{~km}$ of sediment, and the adjacent Qaidam and Junggar basins are estimated to contain 15 and $11 \mathrm{~km}$, respectively. However, these basins contain varied, in part, deep-water sedimentary rocks. Basins containing great thicknesses of sedimentary rocks consisting principally of volcanic arenites are uncommon.

Subduction along the Jabal Burqah belt and the Nabitah belt northwest of Al Hissu appears to be the cause of the generation of arc volcanic rocks lying directly to the northeast, which were in turn the principal source of the sediments forming the Murdama rocks of the Afif belt in the accompanying back-arc basin. At some time, the subduction zone stepped out southwestward to the Nabitah belt, a new volcanic arc was established, and Murdama strata were deposited in the Jabal Hadhah belt and in two other basins lying between Jabal Hadhah and Al Hissu (fig. 2). Although sediment transport directions have not been studied in these basins, volcanic rocks which are possible sediment sources lie to the west of the Jabal Hadhah belt. This scenario requires that the basal strata of the Murdama of these belts be younger than those of the Afif belt; however, sedimenta-

\section{EXPLANATION}

Murdama group

Scattered exposures of gabbro and ultramafic rocks

Masama and Zain formations

Scattered exposures of volcanic rocks in probable source areas for Murdama group

Contact, or limit of scattered exposures, dashed where less certain

$\leftrightharpoons 50 \mathrm{~km}$ Najd fault with displacement removed-Arrows indicate direction of relative movement, value indicates amount of displacement

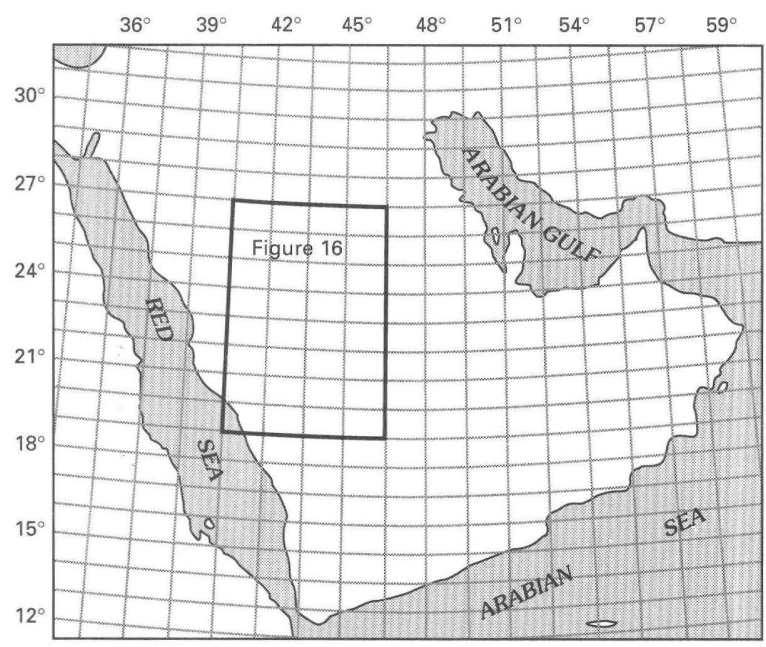

Figure 16.-Continued. tion certainly continued in the Afif belt following the cessation of volcanism, so that the ages of sediments in these basins partly overlap.

The Mistahjed belt is in a similar but more complex situation. As left-lateral displacement on the southernmost Najd fault zone is estimated at $120 \mathrm{~km}$, that much is removed on the palinspastic reconstruction (fig. 16). The serpentinite belt marking the Nabitah fault zone aligns with the serpentinite belt east of Zalm and marks the southward continuation of the subduction zone. Other serpentinite bodies in and north of the reconstructed position of the Mistahjed belt are related to Najd faulting (Greene, in press c) and were not present when Murdama strata were being deposited. As in the Afif belt, volcanic rocks that are slightly older than to, in part, contemporaneous with the Murdama now lie between the Nabitah belt and Murdama rocks, fitting the pattern of a contiguous volcanic arc and back-arc basin, lying above an east-dipping subduction zone.

The Junaynah belt is a yoked basin owing its origin strictly to uplift of the adjacent ranges. It rests on a crustal block lying west of the Nabitah belt, hence has no direct tectonic relationship to Murdama rocks lying east of that belt.

\section{REFERENCES CITED}

Agar, R.A., 1984, Geology of the Zalm quadrangle, sheet 22F, Kingdom of Saudi Arabia: Saudi Arabian Deputy Ministry for Mineral Resources Open-File Report DGMR-OF-04-1, 103 p., scale $1: 250,000$.

- 1986, The Bani Ghay group, sedimentation and volcanism in pull-part grabens of the Najd strike-slip orogen, Saudi Arabian shield: Precambrian Research, v. 31, p. 259-274.

1988, Geologic map of the Zalm quadrangle, sheet 22F, Kingdom of Saudi Arabia: Saudi Arabian Deputy Ministry for Mineral Resources Geoscience Map GM-89C, scale 1:250,000.

Aguttes, J., 1971, Geology and mineral exploration of the Jabal ash Sheba quadrangle: Bureau de Recherches Géologiques et Minières (Saudi Arabian Mission) Report 71-JED-6.

Aldrich, L.T., Brown, G.F., Hedge, C., and Marvin, R., 1978, Geochronologic data for the Arabian Shield: U.S. Geological Survey Saudi Arabian Mission Project Report 240, 20 p.

Al Muallem, M.S., and Smith, J.W., 1984, Geology of the Ar Rawdah quadrangle, sheet 21F, Kingdom of Saudi Arabia: Saudi Arabian Deputy Ministry for Mineral Resources Open-File Report DGMR-OF-03-12, 69 p., scale 1:250,000.

- 1987, Geologic map of the Ar Rawdah quadrangle, sheet 21F, Kingdom of Saudi Arabia: Saudi Arabian Deputy Ministry for Mineral Resources Geoscience Map GM-85-C, scale 1:250,000.

Bramkamp, R.A., Ramirez, L.F., Brown, G.F., and Pocock, A.E., 1963, Geologic map of the Wadi ar Rimah quadrangle, Kingdom of Saudi Arabia: U.S. Geological Survey 
Miscellaneous Geologic Investigations Map I-206, scale 1:500,000.

Brock, M.R., 1983, Reconnaissance geologic map of the Jabal Zain quadrangle, sheet 20/44 A, Kingdom of Saudi Arabia: Saudi Arabian Deputy Ministry for Mineral Resources Open-File Report USGS-OF-03-106, scale $1: 100,000$, summary on map sheet.

Brosset, R., 1979, Geology and mineral exploration of the Bir al Furaysh quadrangle: Bureau de Recherches Géologiques et Minières (Saudi Arabian Mission) Report 79-JED-3.

Brosset, R., and Delfour, J., 1972, Geology and mineral exploration of the Wadi al Jifn quadrangle: Bureau de Recherches Geologiques et Minieres (Saudi Arabian Mission) Report 72-JED-14.

Brown, G.F., and Jackson, R.O., 1960, The Arabian Shield: International Geological Congress, 21st, Copenhagen, 1960, Proceedings, sec. 9, p. 69-77.

Brown, G.F., Jackson, R.O., Bogue, R.G.., and MacLean, W.H., 1963a, Geologic map of the southern Hijaz quadrangle, Kingdom of Saudi Arabia: U.S. Geological Survey Miscellaneous Geologic Investigations Map I-210A, scale 1:500,000.

Brown, G.F., Layne, N.M., Jr., Goudarzi, G.H., and MacLean, W.H., 1963b, Geologic map of the northeastern Hijaz quadrangle, Kingdom of Saudi Arabia: U.S. Geological Survey Miscellaneous Geologic Investigations Map I-205A, scale 1:500,000.

Brown, G.F., Schmidt, D.L., and Huffman, A.C., Jr., 1989, Geology of the Arabian Peninsula: Shield area of western Saudi Arabia: U.S. Geological Survey Professional Paper 560-A, 188 p. includes Geologic map of the Saudi Arabian shield, scale 1:1,000,000.

Cole, J.C., 1985, Reconnaissance geology of the Uglat as Suqur quadrangle, sheet 25/42A, Kingdom of Saudi Arabia: Saudi Arabian Deputy Ministry for Mineral Resources Open-File Report USGS-OF-05-14, scale 1:100,000, $96 \mathrm{p}$.

1986, Geology of the Aban al Ahmar quadrangle, sheet 25F, Kingdom of Saudi Arabia: Saudi Arabian Deputy Ministry for Mineral Resources Open-File Report USGSOF-04-09, 85 p., scale 1:250,000.

- 1988, Geologic map of the Aban al Ahmar quadrangle, sheet 25F, Kingdom of Saudi Arabia: Saudi Arabian Deputy Ministry for Mineral Resources Geoscience Map GM-105-A, scale 1:250,000.

Cole, J.C., and Hedge, C.E., 1986, Geochronologic investigation of the late Proterozoic rocks in the northeastern Shield of Saudi Arabia: Saudi Arabian DMMR Technical Record USGS-TR-05-5, map 1:1,000,000, 82 p.

Cooper, J.A., Stacey, J.S., Stoeser, D.B., and Fleck, R.J., 1979, An evaluation of the zircon method of isotopic dating in the southern Arabian craton: Contributions to Mineralogy and Petrology, v. 68, p. 429-439.

Cornwall, H.R., 1973, Geology of the Wadi Harjab quadrangle, Kingdom of Saudi Arabia: Saudi Arabian Directorate General of Mineral Resources Geologic Map GM-3, 5 p., scale 1:100,000.

Darbyshire, D.P.F., Jackson, N.J., Ramsay, C.R., and Roobol, M.J., 1983, Rb-Sr isotope study of latest Proterozoic volcano-sedimentary belts in the central Arabian Shield: Jour- nal Geological Society of London, v. 140, p. 203-213.

Delfour, J., 1977, Geology of the Nuqrah quadrangle, sheet 25E, Kingdom of Saudi Arabia: Saudi Arabian Deputy Ministry for Mineral Resources Geologic Map GM-28, 32 p., scale 1:250,000.

- 1979, Geology of the Halaban quadrangle, sheet 23G, Kingdom of Saudi Arabia: Saudi Arabian Deputy Ministry for Mineral Resources Geologic Map GM-46-A, 32 p., scale 1:250,000.

1980, Geology of the Wadi ar Rika quadrangle, sheet 22G, Kingdom of Saudi Arabia: Saudi Arabian Deputy Ministry for Mineral Resources Geologic Map GM-51-A, 34 p., scale 1:250,000.

1981a, Geology of the Al Hissu quadrangle, sheet 24E, Kingdom of Saudi Arabia: Saudi Arabian Deputy Ministry for Mineral Resources Geologic Map GM-58-A, 47 p., scale 1:250,000.

- 1981b, Geologic, tectonic and metallogenic evolution of the northern part of the Precambrian Arabian Shield, Kingdom of Saudi Arabia: Bureau de Recherches Géologiques et Minières, Bulletin 2d ser. 2, sect. 2, no. 12, p. 1-19.

Delfour, J., Dhellemmes, R., Elsass, P., Vaslet, D., Brosse, JM., Le Nindre, Y-M., and Dottin, O., 1982, Geology of the Ad Dawadimi quadrangle, sheet 24G, Kingdom of Saudi Arabia: Saudi Arabian Deputy Ministry for Mineral Resources Geologic Map GM-60-A, 36 p., scale $1: 250,000$.

Dickinson, W.R., Helmhold, K.P., and Stein, J.A., 1979, Mesozoic lithic sandstones in central Oregon: Journal of Sedimentary Petrology, v. 49, p. 501-516.

Dickinson, W.R., and Suczek, C.A., 1979, Plate tectonics and sandstone compositions: American Association of Petroleum Geologists Bulletin, v. 63, p. 2164-2182.

Dickinson, W.R., and others, 1983, Provenance of North American Phanerozoic sandstones in relation to tectonic setting: Geological Society of America Bulletin, v. 94, p. 222-235.

du Bray, E.A., 1983a, Reconnaissance geology of the Jabal as Silsilah quadrangle, sheet 26/42D, Kingdom of Saudi Arabia: U.S. Geological Survey Technical Record USGSTR-03-4, 52 p., scale 1:100,000.

1983b, Reconnaissance geology of the Jabal Saq quadrangle, sheet 26/43C, Kingdom of Saudi Arabia: U.S. Geological Survey Open-File Report USGS-OF-03-58, 20 p., scale 1:100,000.

1984, Geology of the Silsilah ring complex, Kingdom of Saudi Arabia: Saudi Arabian Deputy Ministry for Mineral Resources Technical Record USGS-TR-04-19, 78 p.

Engel, A.E.J., Dixon, T.H., and Stern, R.J., 1980, Late Precambrian evolution of Afro-Arabian crust from ocean arc to craton: Geological Society of America Bulletin, v. 91, p. 699-706.

Fitch, F.H., 1980, Saudi Arabian stratigraphic lexicon: Kingdom of Saudi Arabia: Saudi Arabian Deputy Ministry for Mineral Resources Technical Record DM-TR-01-1, 273 p.

Fleck, R.J., Coleman, R.G., Cornwall, H.R., Greenwood, W.R., Hadley, D.G., Schmidt, D.L., Prinz, W.C., and Ratte, J.C., 1976, Geochronology of the Arabian Shield, western Saudi Arabia: K-Ar results: Geological Society of 
America Bulletin, v. 87, p. 9-21.

Fleck, R.J., Greenwood, W.R., Hadley, D.G., Anderson, R.E., and Schmidt, D.L., 1980, Rubidium-strontium geochronology and plate-tectonic evolution of the southern part of the Arabian Shield: U.S. Geological Survey Professional Paper 1131, 38 p.

Fleck, R.J., and Hadley, D.G. 1982, Ages and strontium initial ratios of plutonic rocks in a transect of the Arabian Shield, Kingdom of Saudi Arabia: Saudi Arabian Deputy Ministry for Mineral Resources Open-File Report USGS-OF-03-38, $43 \mathrm{p}$.

Frisch, W., and Al-Shanti, A., 1977, Ophiolite belts and the collision of island arcs in the Arabian Shield: Tectonophysics, v. 43, p. 293-306.

Gonzalez, L., 1974, Geology of the Jabal Ishmas quadrangle, Kingdom of Saudi Arabia, with a section on Aeromagnetic studies by V.J. Flanagan: U.S. Geological Survey Saudi Arabian Mission Project Report 186, 34 p., scale $1: 100,000$.

Greene, R.C., 1983, Stratigraphy of the Murdama formation between Afif, Halaban, and As Sawadah, Kingdom of Saudi Arabia: Saudi Arabian Deputy Ministry for Mineral Resources Open-File Report DM-OF-03-2, 35 p.

- in press a, Stratigraphy of the Murdama formation between Wadi al Jarir, Nuqrah, Jabal Hibshi, and Jabal as Silsilah, Kingdom of Saudi Arabia: Saudi Arabian Deputy Ministry for Mineral Resources Open-File Report USGSOF-08-1 (IR-783), in press.

- in press $b$, Stratigraphy of the Murdama formation between Jabal Hadhah, Jabal Yafikh, Jabal Bijad, and Junaynah, Kingdom of Saudi Arabia: Saudi Arabian Deputy Ministry for Mineral Resources Open-File Report USGS-OF-08-2 (IR-784), in press.

- in press c, Reconnaissance geology of the Jabal Dalfa quadrangle, sheet 21/43C, Kingdom of Saudi Arabia: Saudi Arabian Deputy Ministry for Mineral Resources Geologic Map, scale 1:100,000, in press.

Greenwood, W.R., 1981, Geology of the Jabal Al Quar quadrangle, sheet 19G, Kingdom of Saudi Arabia, with a geographic map, compiled by F.J. Fuller: U.S. Geological Survey Saudi Arabian Mission Miscellaneous Document 49 (Interagency report 389), 33 p., scale 1:250,000.

Greenwood, W.R., Hadley, D.G., Anderson, R.E., Fleck, R.J., and Schmidt, D.L., 1976, Late Proterozoic cratonization in southwestern Saudi Arabia: Philosophical Transactions of the Royal Society of London, ser. A., v. 280, p. 517-527.

Greenwood, W.R., Jackson, R.O., and Johnson, P.R., 1986, Geologic map of the Jabal al Hasir quadrangle, sheet 19F, Kingdom of Saudi Arabia: Saudi Arabian Deputy Ministry for Mineral Resources Geoscience Map GM-94, scale $1: 250,000$.

Greenwood, W.R., Stoeser, D.B., Fleck, R.J., and Stacey, J.S, 1982, Late Proterozoic island-arc complexes and tectonic belts in the southern part of the Arabian Shield, Kingdom of Saudi Arabia: Saudi Arabian Deputy Ministry for Mineral Resources Open-File Report USGS-OF-02-8, 46 p.

Griscom, A., 1982, An aeromagnetic interpretation of eleven map sheets, scale 1:250,000 in the southern Najd and part of the southern Tuwayq quadrangle, Kingdom of Saudi Arabia: Saudi Arabian Deputy Ministry for Mineral Re- sources Open-File Report USGS-OF-02-70, 21 p.

Hadley, D.G., 1974, Geologic map of the Wayban quadrangle, Kingdom of Saudi Arabia: Saudi Arabian Deputy Ministry for Mineral Resources Geologic Map GM-7, 10 p., scale $1: 100,000$.

1976, Geology of the Bi'r Juqjuq quadrangle, sheet 21/ 43 D, Kingdom of Saudi Arabia: Saudi Arabian Deputy Ministry for Mineral Resources Geologic Map GM-26, 30 p., scale 1:100,000.

Hadley, D.G., and Schmidt, D.L., 1979, Proterozoic sedimentary rocks and basin of the Arabian Shield and their evolution: U.S. Geological Survey Saudi Arabian Project Report SA(IR)-242, $41 \mathrm{p}$.

Hamilton, Warren, 1979, Tectonics of the Indonesian region: U.S. Geological Survey Professional Paper 1078, 345 p.

Healy, J.H., Mooney, W.D., Blank, H.R., Gettings, M.E., Kohler, W.M., Lamson, R.J., and Leone, L.E., 1982, Saudi Arabian seismic deep refraction profile: Final project report: Saudi Arabian Deputy Ministry for Mineral Resources Open File Report USGS-OF-02-37, 137 p.

Hsu, K.H., 1988, Relict back-arc basins: Principles of recognition and possible new examples from China, in Kleinspehn, K.L., and Payola, Chris, eds., New perspectives in basin analysis, New York, Springer-Verlag, p. 246-263.

Jackson, R.O., Bogue, R.G., Brown, G.F., and Gierhart, R.D., 1963, Geologic map of the southern Najd quadrangle, Kingdom of Saudi Arabia: U.S. Geological Survey Miscellaneous Geologic Investigations Map I-211A, scale 1:500,000.

Johnson, P.R., 1982, Geologic reconnaissance map of the Miskah quadrangle, Kingdom of Saudi Arabia: Riofinex Geological Mission, Ltd., scale 1:250,000, 24 p.

Johnson, P.R., and Williams, P.L., 1984, Geology of the Precambrian rocks of the Jabal Habashi quadrangle, sheet 26F, Kingdom of Saudi Arabia: Saudi Arabian Deputy Ministry for Mineral Resources Open-File Report USGSOF-04-10, 87 p., scale 1:250,000.

Kellogg, K.S., 1982a, Reconnaissance geology of the Jabal Bijad quadrangle, sheet 20/43D, Kingdom of Saudi Arabia: Saudi Arabian Deputy Ministry for Mineral Resources Open-File Report USGS-OF-02-55, 2 sheets, scale 1:100,000.

1982b, Reconnaissance geology of the Jabal Jasl' quadrangle, sheet 20/44C, Kingdom of Saudi Arabia: Saudi Arabian Deputy Ministry for Mineral Resources Open-File Report USGS-OF-02-56, 2 sheets, scale 1:100,000.

1983, Geology of the Precambrian rocks in the Wadi Tathlith quadrangle, sheet 20G, Kingdom of Saudi Arabia: Saudi Arabian Deputy Ministry for Mineral Resources Open-File Report USGS-OF-04-1, 37 p., scale 1:250,000.

Kellogg, K.S., Janjou, Dominique, Minoux, Laurent, and Fourniguet, Jackie, 1986, Geologic map of the Wadi Tathlith quadrangle, sheet 20G, Kingdom of Saudi Arabia: Saudi Arabian Deputy Ministry for Mineral Resources Geoscience Map GM-103-C, scale 1:250,000.

Kemp, J., Pellaton, C., and Calvez, J.-Y., 1982a, Cycles in the chelogenic evolution of the Precambrian Shield of part of northwestern Saudi Arabia, Kingdom of Saudi Arabia: 
Saudi Arabian Deputy Ministry for Mineral Resources Professional Papers, no. 1, p. 27-41.

Kemp, J., Gros, Y., and Prian, J.P., 1982b, Geologic map of the Mahd adh Dhahab quadrangle, sheet 23E, Kingdom of Saudi Arabia: Saudi Arabian Deputy Ministry for Mineral Resources Geologic Map GM-64A, 39 p., scale 1:250,000.

Leca, X., Letalenet, J., and Shanti, M., 1972, Geology and mineral exploration of the Al Maslum quadrangle, Photomosaic 114 East: Bureau de Recherches Géologiques et Minières (Saudi Arabian Mission) Report 72-JED-13, 28 p., scale 1:100,000.

Letalenet, J., 1974, Geology and mineral exploration of the Jabal al Murdama quadrangle, 23/43A: Bureau de Recherches Géologiques et Minières (Saudi Arabian Mission) Report 74-JED-10, 35 p., scale 1:100,000.

- 1977a, Geology and mineral exporation of the Jabal Abha quadrangle, 24/40D: Bureau de Recherches Géologiques et Minières (Saudi Arabian Mission) Report 77-JED-23, 28 p., scale 1:100,000.

- 1977b, Geology and mineral exploration of the Wadi ash Shaqrah quadrangle, 24/40C: Bureau de Recherches Géologiques et Minières (Saudi Arabian Mission) Report 77-JED-13, 2 p., scale 1:100,000.

-1979, Geologic map of the Afif qudrangle, sheet 23F, Kingdom of Saudi Arabia: Saudi Arabian Deputy Ministry for Mineral Resources Geologic Map GM-47-A, 20 p., scale $1: 250,000$.

Letalenet, J., Bois, J., Arinan, A., Gazzaz, A.R., Pflaum, J., and Shanti, M., 1972, Geology and mineral exploration of the Jibal ar Raqabah quadrangle, Photomosaic 119 West: Bureau de Recherches Géologiques et Minières (Saudi Arabian Mission) Report 72-JED-20, 28 p.

Manivit, Jacques, Pellaton, Claude, Vaslet, Denis, Le Nindre, Y.M., Brosse, J.M., and Fourniguet, Jackie, 1985, Geologic map of the Wadi al Mulayh quadrangle, sheet $22 \mathrm{H}$, Kingdom of Saudi Arabia: Saudi Arabian Deputy Ministry for Mineral Resources Geoscience Map GM-92-A, scale 1:250,000.

Miall, A.D., 1978, Tectonic setting and syndepositional deformation of molasse and other non-marine paralic sedimentary basins: Canadian Journal of Earth Science, v. 15, p. 1613-1632.

1981, Alluvial sedimentary basins: Tectonic setting and architecture, in Miall, A.D., ed., Sedimentation and tectonics in alluvial basins: Geological Association of Canada Special Paper 23, p. 1-34.

Moore, J.M.M., 1979, Tectonic of the Najd transcurrent fault system, Suadi Arabia: Journal of Geological Society of London, v. 136, p. 441-454.

Overstreet, W.C., 1978, A geological and geochemical reconnaissance of the Tathlith $1^{\circ}$ quadrangle, sheet $19 / 43$, Kingdom of Saudi Arabia: U.S. Geological Survey Saudi Project Report SA(IR)-230, 132 p., 4 maps, scale $1: 100,000$.

Overstreet, W.C., and Whitlow, J.W., 1972, Reconnaissance geology of the Precambrian rocks of the Bi'r Ghamrah quadrangle, Kingdom of Saudi Arabia: U.S. Geological Survey Saudi Arabian Project Report SA(IR)-128, 33 p., scale 1:250,000.

Pallister, J.S., 1983, Reconnaissance geology of the Harrat al
Hutaymah quadrangle, sheet 26/42A, Kingdom of Saudi Arabia: Saudi Arabian Deputy Ministry for Mineral Resources Open-File Report USGS-OF-04-46, 77 p., scale $1: 100,000$.

Palmer, A.R., 1983, Decade of North American Geology 1983 geologic time scale: Boulder, Geological Society of America, 2 p.

Pellaton, Claude, 1981, Geologic map of the Al Madinah quadrangle, sheet 24D, Kingdom of Saudi Arabia (with topographic base): Saudi Arabian Deputy Ministry for Mineral Resources Geoscience Map GM-52-A, 19 p., scale $1: 250,000$.

1985, Geologic map of the Miskah quadrangle, sheet 24F, Kingdom of Saudi Arabia: Saudi Arabian Deputy Ministry for Mineral Resources Geoscience Map GM-99A, scale 1:250,000.

Pettijohn, F.J., 1975, Sedimentary rocks, 3d edition: New York, Harper and Row, 628 p.

Quick, J.E., and Doebrich, J.L., 1987, Geologic map of the Wadi ash Shubah quadrangle, sheet $26 \mathrm{E}$, Kingdom of Saudi Arabia: Saudi Arabian Deputy Ministry for Mineral Resources Geoscience Map GM-108-C, scale 1:250,000.

Rock Color Chart Committee, 1975, Rock color chart: Boulder, Geological Society of America.

Schmidt, D.L., 1981, Geology of the Jabal Yafikh quadrangle, sheet 20/43 B, Kingdom of Saudi Arabia: U.S. Geological Survey Saudi Arabian Mission Miscellaneous Document 39 (Interagency Report 397), 99 p., scale 1:100,000.

1985, Geology of the Al Junaynah quadrangle, sheet 20/42D, Kingdom of Saudi Arabia: Saudi Arabian Deputy Ministry for Mineral Resources Geologic Map GM-71, scale $1: 100,000$.

Schmidt, D.L., Hadley, D.G., Greenwood, W.R., Gonzalez, L., Coleman, R.G., and Brown, G.F., 1973, Stratigraphy and tectonism of the southern part of the Precambrian Shield of Saudi Arabia: Saudi Arabian Directorate General of Mineral Resources Bulletin 8, 13 p.

Schmidt, D.L., Hadley, D.G., and Stoeser, D.B., 1979, Late Proterozoic crustal history of the Arabian Shield, southern Najd province, Kingdom of Saudi Arabia, in Evolution and mineralization of the Arabian-Nubian Shield, v. 2: New York, Pergamon (King Abdulaziz University, Institute of Applied Geology, Bulletin No. 3, v. 2), p. 41-58.

Simons, F.S., 1984, Geologic map of the Wadi Bishah quadrangle, sheet 20F, Kingdom of Saudi Arabia: Deputy Ministry for Mineral Resources Open-File Report USGS-OF04-7, 78 p., scale 1:250,00.

1988, Geologic map of the Wadi Bishah quadrangle, sheet 20F, Kingdom of Saudi Arabia: Saudi Arabian Deputy Ministry for Mineral Resources Geoscience Map GM-97-A, scale i:250,000.

Stacey, J.S., and Stoeser, D.B., 1983, Distribution of oceanic and continental leads in the Arabian-Nubian Shield: Contributions to Mineralogy and Petrology, v. 84, p. 91-105.

Stacey, J.S., Stoeser, D.B., Greenwood, W.R., and Fischer, L.B., 1984, U-Pb zircon geochronology and geologic evolution of the Halaban-Al Amar region of the eastern Arabian Shield, Kingdom of Saudi Arabia: Journal of the Geological Society of London, v. 141, p. 1043-1055.

Steiger, R.H., and Jager, E., 1977, Subcommision on geochro- 
nology: Convention on the use of decay constants in geoand cosmochronology: Earth and Planetary Science Letters, v. 36, p. 359-362.

Stoeser, D.B., and Camp, V.E., 1985, Pan-African micro-plate accretion of the Arabian Shield: Geological Society of America Bulletin, v. 96, p. 817-826.

Stoeser, D.B., and Stacey, J.S., 1988, Evolution, U-Pb geochronology, and isotope geology of the Pan-African Nabitah orogenic belt of the Saudi Arabian Shield, in El Gaby, Samir, and Greiling, R.O., eds., The Pan African Belt of northeast Africa and adjacent areas: Wiesbaden, Friedrich Vieweg, p. 227-288.

Stoeser, D.B., Stacey, J.S., Greenwood, W.R., and Fisher, L.B., $1984, \mathrm{U} / \mathrm{Pb}$ zircon geochronology of the southern part of the Nabitah mobile belt and pan-African continental collision in the Saudi Arabian Shield: Saudi Arabian Deputy Ministry for Mineral Resources Technical Record USGSTR-04-5, 88 p.

Stratigraphic Committee, 1979, Directorate General of Mineral Resources, Saudi Arabian code of lithostratigraphic classification and nomenclature, first edition: Deputy Ministry for Mineral Resources Technical Manual TM-1979-1, 15 p.

- 1984, Directorate General of Mineral Resources, Saudi Arabian code of lithostratigraphic classification and nomenclature, second edition: Saudi Arabian Deputy Ministry for Mineral Resources Technical Manual DM-TM-041, $16 \mathrm{p}$.

Struckless, J.S., Hedge, C.E., Wenner, D.B., and Nkomo, I.T., 1984, Isotopic studies of postorogenic granites from the northeastern Arabian Shield, Kingdom of Saudi Arabia: Saudian Arabian Deputy Ministry for Mineral Resources Open-File Report USGS-OF-04-42, 40 p.

Thieme, J.G., 1985, Geologic map of the Jabal Khida quadrangle, sheet $21 \mathrm{G}$, Kingdom of Saudi Arabia: Saudi Arabian Deputy Ministry for Mineral Resources Open-File Report OF-04-2, scale 1:250,000.

- 1988, Geologic map of the Jabal Khida quadrangle, sheet 21G, Kingdom of Saudi Arabia: Saudi Arabian Deputy Ministry for Mineral Resources, Geoscience map GM-90-C, scale 1:250,000.

U.S. Geological Survey and Arabian-American Oil Company (ARAMCO), compilers, 1963, Geologic map of the Arabian Peninsula: U.S. Geological Survey Miscellaneous Geologic Investigations Map I-270-A, scale 1:2,000,000.
Vaslet, Denis, Pellaton, Claude, Manivit, Jacques, Le Nindre, Y.M., Brosse, J.M., and Fourniguet, Jackie, 1985, Geologic map of the Sulayyimah quadrangle, sheet $21 \mathrm{H}$, Kingdom of Saudi Arabia: Saudi Arabian Deputy Ministry for Mineral Resources Geoscience Map GM-100-A, scale 1:250,000.

Wallace, C.A., 1986, Lithofacies and depositional environment of the Maraghan formation, and speculation of the origin of gold in ancient mines, An Najady area, Kingdom of Saudi Arabia: Saudi Arabian Deputy Ministry for Mineral Resources Open-File Report USGS-OF-06-6, 19 p.

Wallace, C.A., and Rowley, P.D., 1986, Reconnaissance study of the Murdama group and related formations, main Murdama basin, Kingdom of Saudi Arabia: Administrative report for USGS Saudi Arabian Mission.

Wentworth, C.K., 1922, A scale of grade and class terms for clastic sediments: Journal of Geology, v. 30, p. 377-392.

Williams, P.L., 1983, Reconnaissance geology of the Samirah quadrangle, sheet 26/42C, Kingdom of Saudi Arabia: Saudi Arabian Deputy Ministry for Mineral Resources Open-File Report USGS-OF-04-3, 33 p., scale 1:100,000.

Williams, P.L. and Simonds, F.W., 1985, Reconnaissance geology of the Al Ba'ayith quadrangle, sheet 26/41D, Kingdom of Saudi Arabia: Saudi Arabian Deputy Ministry for Mineral Resources Open-File Report USGS-OF-05-18, 38 p., scale 1:100,000.

Williams, P.L., Vaslet, Denis, Johnson, P.R., Berthiaux, Alain, Le Strat, Paul, and Fourniguet, Jackie, 1986, Geologic map of the Jabal Habashi quadrangle, sheet 26F, Kingdom of Saudi Arabia: Saudi Arabian Deputy Ministry for Mineral Resources Geoscience Map GM-98-C, scale $1: 250,000$.

Worl, R.G., 1980, Gold deposits associated with the Jabal Ishmas-Wadi Tathlith fault zone, in Evolution and mineralization of the Arabian-Nubian Shield, vol. 2: New York, Pergamon (King Abdulaziz University, Institute of Applied Geology, Bulletin 3, v. 4), p. 61-69.

Yeslam, A.R., 1974, Geologic map of the Wadi al Gemrah quadrangle sheet 21/44B, Kingdom of Saudi Arabia: Saudi Arabian Directorate General for Mineral Resources Report DGMR no. 519 , scale $1: 100,000$.

Young, E.J., 1982, Reconnaissance geology of the Wadi al Jarir quadrangle, sheet 25/42C, Kingdom of Saudi Arabia: Saudi Arabian Deputy Ministry for Mineral Resources Open-File Report USGS-OF-04-54, 33 p., scale 1:100,000. 


